\title{
COAL SURFACE CONTROL FOR ADVANCED
}

PHYSICAL FINE COAL CLEANING TECHNOLOGIES

DOE Contract No. DE-AC22-88PC88877

\section{QUARTERLY REPORT}

(April 1, 1990 - June 30, 1990)

B. I. Morsi

S. - H. Chiang

A. Sharkey

J. Blachere

G. Klinzing

G. Araujo

R. Venkatadri
H. Bi

P. Campbell

M. Ciocco

L. Hittle

S. Kim

Y. Kim

L. Perez

\section{Chemical and Petroleum Engineering Department \\ University of Pittsburgh \\ Pittsburgh, PA 15261}

\section{DISCLAIMER}

This report was prepared as an account of work sponsored by an agency of the United States Government. Neither the United States Government nor any agency thereof, nor any of their employees, makes any warranty, express or implied, or assumes any legal liability or responsibility for the accuracy, completeness, or usefulness of any information, apparatus, product, or process disclosed, or represents that its use would not infringe privalely owned rights. Refer. ence herein to any specific commercial product, process, or service by trade name, trademark, manufacturer, or otherwise does not necessarily constitute or imply its endorsement, recommendation, or favoring by the United States Government or any agency thereof. The views and opinions of authors expressed herein do not necessarily state or reflect those of the United States Government or any agency thereof

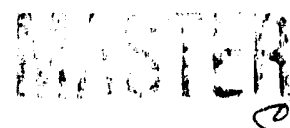




\section{TABLE OF CONTENTS}

LIST OF TABLES

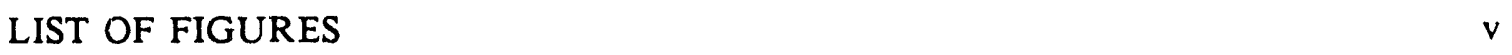

SUMMARY

1.0 INTRODUCTION 3

2.0 TASK 7: EXPLORATORY R\&D AND SUPPORT 5

2.1 Quantitative Distribution of Iron Species 5

2.2 Surface Functional Groups $\quad 6$

2.2.1 Comparison of Wet and Dry Ground Samples 7

2.2.2 Study of Illinois \# 6 Coal Wet Ground Using Additives 7

2.2.3 Study of Wet Grinding Using Tall Oil 7

2.3 Surface Composition 9

2.3.1 Elemental Distribution of Coal Samples Wet Ground Without Additives $\quad 9$

2.3.2 Elemental Distribution of Coal Samples Wet Ground
With Tall Oil

2.4 Direct Determination of Pyrite by X-ray Diffraction 11

2.5 Electron Microprobe Measurements $\quad 12$

$\begin{array}{ll}2.6 \text { Coal Morphology } & 13\end{array}$

$\begin{array}{ll}2.7 \text { Zeta Potential Measurements } & 13\end{array}$

2.8 Pyrite Size Distribution. 14

2.9 Statistical Analysis of Grinding Study Data 15

$\begin{array}{ll}2.10 \text { Grinding Using Light Hydrocarbons } & 18\end{array}$

$\begin{array}{ll}2.10 .1 \text { Effects of N-pentarie } & 18\end{array}$

$\begin{array}{ll}2.10 .2 \text { Effects of Cyclohexane } & 19\end{array}$

2.10.3 Effects of N-heptane 20

2.11 Optimization of the Agglomeration Process 20

2.11.1 Study of the Effects of the Grinding Method 20

2.11.2 Study of the Effects of the Grinding Time 20

2.11.3 Study of the Effects of the Agglomeration Time 21

2.11.4 Study of the Effects of the Pentane to Coal Ratio 22 
3.0 CONCLUSIONS

4.0 WORK SCHEDULE AND PLAN 27

$\begin{array}{ll}5.0 \text { REFERENCES } & 28\end{array}$

$\begin{array}{ll}\text { APPENDIX A: TABLES } & 29\end{array}$

APPENDIX B: FIGURES

APPENDIX C: PYRITE SIZE DISTRIBUTION CALCULATION 97

APPENDIX D: AGGLOMERATION TEST RESULTS USING LIGHT
HYDROCARBONS DURING GRINDING

APPENDIX E: OPTIMIZATION OF THE AGGLOMERATION PROCESS

TEST RESULTS

119 


\section{LIST OF TABLES}

Table 2.1-1 Mőssbauer Spectroscopy Results

Table 2.2.1-1 Oxidation Indices and 95\% Confidence Intervals for Illinois \# 6 and Pittsburgh \# 8 Coals Ground to 200 mesh $\times 0$ in Air and Water

Table 2.2.2-1 Oxidation Indices and 95\% Confidence Intervals for Illinois \# 6 Wet Ground to 200 mesh $\times 0$ with Various Additives

Table 2.2.3-1 Oxidation Indices and 95\% Confidence Intervals for Illinois \# 6 and Pittsburgh \# 8 Coals Wet Ground to 200 mesh x 0 with Tall Oil Added

Table 2.3.1-1 Change in Surface Elemental Composition Relative to Feed for Pittsburgh \# 8 Wer Ground Without Additives

Table 2.3.1-2 Change in Surface Elemental Composition Relative to Feed for Illinois \# 6 Wet Ground Without Additives

Table 2.3.2-1 Change in Surface Elemental Composition Relative to Feed for Pittsburgh \# 8 Wet Ground With 200 ppm of Tall Oi!

Table 2.3.2-2 Change in Surface Elemental Composition Relative to Feed for Illinois \# 6 Wet Ground With 200 ppm of Tall Oil

Table 2.4-1 XRD Pyrite Determination Results

Table 2.7-1 Zeta Potential of Agglomeration Test Feed Samples 39

Table 2.8-1 Pyrite Size Distribution for 28 mesh x 0 Upper Freeport Coal 40

Table 2.8-2. Pyrite Size Distribution for 28 mesh x 0 Pittsburgh 8 Coal 41

Table 2.8-3 Pyrite Size Distribution for 28 mesh $x 0$ Illinois 0 Coal 42

Table 2.8-4 Pyrite Size Distribution for 200 mesh $\times 0$ Upper Freeport Coal 43

Table 2.8-5 Pyrite Size Distribution for 200 mesh x 0 Pittsburgh \# 8 Coal 44

Table 2.8-6 Pyrite Size Distribution for 200 rresh $\times 0$ Illinois \# 6 Coal 45

Table 2.9-1 Experimental Conditions for Grinding Study 46

Table 2.9-2 Operation Variables Significance on Energy Recovery 47

Table 2.9-3 Cperation Variables Significance on Ash Rejection 48

Table 2.9.4 Average Values of Energy Recovery for the Statisticisily

Significant Variables and Interactions

Table 2.9.5 Average Values of ih Rejection for the Statistically

Significant Variables and Interactions

Table 2.10-1 Agglomeration Test Results Using Light Hydrocarbons for Upper Freeport Coal

Table 2.10-2 Agglomeration Test Results Using Light Hydrocarbons for Pittsburgh \#8 Coal 
Table 2.10-3 Agglomeration Test Results Using Light Hydrocarbons

for Illinois \#6 Coal

Table 2.10-4 Standard Deviation Within Replicates for the Agglomeration Tests Using Light Hydrocarbons During Grinding

Table 2.10.1 -1 Results of the Statistical Analysis of the Effects of Grir ding Using $\mathrm{N}$-pentane

Table 2.10.2-1 Results of the Statistical Analysis of the Effects of Grinding Using Cyclohexane

Table 2.10.3-1 Results of the Statistical Analysis of the Effects of Grinding Using $\mathrm{N}$-heptane

Table 4.0-1 Work Schedule 


\section{LIST OF FIGURES}

Figure 2.1-1 Mőssbauer Spectrum of Feed Sample of Pittsburgh \# 8 Coal

Wet Ground to 200 mesh $x 0$ Using 200 ppm of Tall Oil

Figure 2.1-2 Mössbauer Spectrum of Product Sample of Pittsburgh \# 3 Coal Wet Ground to 200 mesh $\times 0$ Using 200 ppm of Tall Oil 61

Figure 2.1-3 Mőssbauer Spectrum of Refuse Sample of Pittsburgh \# 8 Coal Wet Ground to 200 mesh $\times 0$ Using 200 ppm of Tall Oil

Figure 2.2.1-1 Comparison of Oxidation Indices for Feed and Product Samples of 200 mesh $\times 0$ Illinois \# 6 Coal Dry and Wet Ground

Figure 2.2.1-2 Comparison of Oxidation Indices for Feed and Product Samples of 200 mesh x 0 Pittsburgh \# 8 Coal Dry and Wet Ground

Figure 2.2.2-1 Comparison of Oxidation Indices for Feed and Product Samples of 200 mesh $\times 0$ Illinois \# 6 Coal Wet Ground With and Without Additives

Figure 2.2.3-1 Comparison of Oxidation Indices for Feed and Product Samples of 200 mesh $\times 0$ Illinois \# 6 Coal Wet Ground With and Without Tall Oil

Figure 2.2.3-2 Comparison of Oxidation Indices for Feed and Product Samples of 200 mesh $\times 0$ Pittsburgh \# 8 Coal Wet Ground With and Without Tall Oil

Figure 2.3.1-1 LAMMA Results for Pittsburgh \#8 Coal Wet Ground to 200 mesh $\times 0$

Figure 2.3.1-2 LAMMA Results for Iron in Illinois \# 6 Coal Wet Ground to 200 mesh $\times 0$

Figure 2.3.1-3 LAMMA Results for Illinois \# 6 Coal Wet Ground to 200 mesh $\times 0$

Figure 2.3.2-1 LAMMA Results for Sulfur in Pittsburgh \# 8 Coal Wet Ground to 200 mesh $\times 0$

Figure 2.3.2-2 LAMMA Results for Iron in Pittsburgh \# 8 Coal Wet Ground to 200 mesh $\times 0$

Figure 2.3.2-3 LAMMA Results for Pittsburgh \# 8 Coal Wet Ground to 200 mesh $\times 0$ With $200 \mathrm{ppm}$ of Tall Oil

Figure 2.3.2-4 Comparison Between Agglomeration Results and LAMMA Data for Pittsburgh \#8 Coal

Figure 2.3.2-5 LAMMA Results for Sulfur in Illinois \# 6 Coal Wet Ground to 200 mesh $\times r$

Figure 2.3.2-6 LAMMA Results for Illinois \# 6 Coal Wet Ground to 200 mesh $\times 0$ With $200 \mathrm{ppm}$ of Tall Oil

Figure 2.8-1 Pyrite Association for 28 mesh $x 0$ Samples 
Figure 2.8-2 Pyrite Association for 200 mesh x 0 Samples 78

Figure 2.9-1 Effect of Particle Size and Grinding Method on Energy Recovery 79

Figure 2.9-2 Effect of Particle Size and Grinding Method on Ash Rejection $\quad 80$

Figure 2.10.1-1 Effect of the Addition of N-pentane During Grinding on Agglomeration Performance for Upper Freeport Coal

Figure 2.10.1-2 Effect of the Addition of N-pentane During Grinding on Agglomeration Performance for Pittsburgh \# 8 Coal

Figure 2.10.2-1 Effect of the Addition of Cyclohexane During Grincling on Agglomeration Performance for Illinois \# 6 Coal

Figure 2.10.3-1 Effect of the Addition of N-heptane During Grinding on Agglomeration Performance for Pittsburgh \# 8 Coal

Figure 2.11.1-1 Effect of Grinding Method on Energy Recovery for Pittsburgh \# 8 Coal

Figure 2.11.1-2 Effect of Grinding Method on Ash Rejection for Pittsburgh \#8 Coal

Figure 2.11.:-3 Effect of Grinding Method on Pyritic Sulfur Rejection for Pittsburgh \# 8 Coal

Figure 2.11.2-1 Effect of Grinding Time on Particle Size for Pittsburgh \# 8 Coal

Figure 2.11.2-2 Effect of Grinding Time on Energy Recovery for Pittsburgh \# 8 Coal

Figure 2.11.2-3 Effect of Grinding Time on Ash Rejection for Pittsburgh \#8 Coal 90

Figure 2.11.3-1 Effect of Agglomeration Time on Energy Recovery 91

Figure 2.11.3-2 Effect of Agglomeration Time on Ash Rejection 92

Figure 2.11.3-3 Effect of Agglomeration Time on Pyritic Sulfur Rejection 93

Figure 2.11.4-1 Effect of Pentane to Coal Ratio (PCR) on Energy Recovery for Pittsburgh \# 8 Coal

Figure 2.11.4-2 Effect of Pentane to Coal Ratio (PCR) on Ash Rejection for Pittsburgh \#8 Coal

Figure 2.11.4-3 Effect of Pentane to Coal Ratio (PCR) on Pyritic Sulfur Rejection for Pittsburgh \# 8 Coal

Figure $\mathrm{C}-1$ Geometry Involved in the Intersection of a Sphere by a Plane Within the Slice $h$ 


\section{SUMMARY}

During this reporting period, research efforts were focused on Task 7 . The progress achieved in this task is summarized in the following.

Several analytical techniques developed in Task 3 were utilized during this quarter to characterize samples from the agglomeration tests performed using $n$-pentane as agglomerant. Mössbauer spectroscopy was used for the identifit $\lrcorner$ tion and quantification of iron sulfides and iron sulfate. Surface functional groups were analyzed using DRIFT spectroscopy. Surface composition analysis were conducted using LAMMA and the electron microprobe (EPMA). SEM was used for morphological analysis. The results of these analyses are being used to relate the agglomeration results with the changes that the surface modifications techniques caused on the properties of the coal samples.

A method for direct determination of pyrite using $\mathrm{X}$-ray diffraction is currently being developed. Preliminary results compared well with pyritic sulfur analyses performed using ASTM standard method.

Zeta potential measurements of samples ground to 200 mesh $\times 0$ in the presence of light hydrocarbons indicate that for Pittsburgh \# 8 and Illinois \# 6 coals the addition of these hydrocarbons shifted the zeta potential toward the isoelectric point. For Upper Freeport coal, however, no clear trend was observed.

A comparison of the volume distribution data for 28 mesh $\times 0$ and 200 mesh $\times 0$ pyrite particles for Upper Freeport and Pittsburgh \# 8 coals showed that a significant reduction in the amount of locked and semi-locked pyrite occurred when the sample was ground finer. However, this was not the case for Illinis \# 6 coal.

Follow-up agglomeration tests were performed using both dry and wet ground coals in order to complete and verify the results of the grinding study conducted in Task 5. The statistical significance of the effects of process variables on agglomeration performance were determined. The coal particle size was found to have the most statistically significant effect on energy recovery whereas grinding method had the greatest influence on ash rejection. 
The analysis of the interaction between particle size and grinding method indicated that wet grinding to 200 mesh $\times 0$ resulted in the best performance for the three coals studied

Follow-up agglomeration tests were conducted using light hydrocarbons as additives during grinding. The new results were combined with previous data to asses the effect of the hydrocarbon to coal ratio on agglomeration performance. The most significant effect observed in these tests was the increase in energy recovery and the decreases in asl and pyritic sulfur rejection for Pittsburgh \# 8 coal as a result of the addition of $n$ heptane.

The optimization of the agglomeration process using $n$-pentane as the agglomerant was continued by performing several series of tests in which the effects of different feed preparation procedures and operation variables on agglomeration performance were investigated.

Lower energy recoveries, ash and pyritic sulfur rejertions were obtained for Pittsburgh \# 8 coal samples ground for 20 hours in the ceramic jar mill as compared with those ground for $15 \mathrm{~min}$ in the stirred ball mill. Grinding for longer time in th, stirred ball mill was also found to be detrimental to the agglomeration performance.

For Upper Freeport and Pittsburgh \# 8 coals, an agglomeration time of 60 seconds was sufficient to attain an energy recovery close to $100 \%$. For Illinois \#6, however, a longer time is needed since for an agglomeration time of 60 seconds the energy recovery was only $70 \%$. For Pittsburgh \# 8 and Illinois \#6 coals, no effect on ash rejection ws observed for agglomeration times longer than 30 seconds. For Upper Freeport coal, however, ash rejection decreased as agglomeration time increased. 


\subsection{INTRODUCTION}

This quarterly report covers the technical progress achieved from April 1 through June 31, 1990 on the Coal Surface Control for Advanced Physical Fine Coal Cleaning Technologies project, under PETC/DOE Contract No. DE-AC22-88PC88877.

The overall objective of the project is to develop techniques for coal surface control prior to the advanced physical fine coal cleaning process of selective agglomeration in order to achieve $90 \%$ pyrite sulfur rejection at a energy recovery greater than $90 \%$ based on run-of-mine coal. The surface control is meant to encompass storage, grinding environments and media, surface modification during grinding and laboratory beneficiation testing. The project includes the following tasks:

- Task 1: Project Planning

- $\quad$ Task 3: Method for Analysis of Samples

- $\quad$ Task 4: Development of Standard Beneficiation Test

- Task 5: Grinding Studies

- $\quad$ Task 6: Modification of Particle Surface

- $\quad$ Task 7: Exploratory R\&D and Support.

The coal samples used in this project include three base coals, Upper Freeport - Indiana County, PA, Pittsburgh \#8 - Belmont County, OH, and Illinois \#6 - Randolph County, IL, and three other coals, Upper Freeport - Grant County, WV, Kentucky \# 9 Hopkins County, KY, and Wyoclak - Campbeil County, WY. During this reporting period, no drums of coal were received.

The project work plan (Task 1) was submitted ') tha DOE and was approved on $12 / 5 / 1988^{(2)}$. Tasks 3 and 4 were completed, and the analytical methods established and tested for the characterization of coal samples and the experimental procedures developed for the agglomeration tests were reported in the first Annual Report ${ }^{(1)}$. Tasks 5 and 6 were completed in the preceding quarter and the results and conclusions of 
grinding and surface modification studies using the three base coals were also reported in the first Annual Report ${ }^{(1)}$.

During this quarter the research effort was focused on Task 7, Exploratory Research \& Development and Support. Progress in this task of the project is presented in this report. 


\subsection{TASK 7: EXPLORATORY R\&D AND SUPPORT}

The objective of Task 7 is to explore new and promising avenues leading to effective surface control for selective agglomeration processes and to provide support services to the DOE's Engineering Developrnent Program. Based on the acconiplishments in Tasks $1,3,4,5$, and 6 of the project, the main objectives of Task 7 are:

1. To improve and optimize the coal surface control techniques developed in Tasks 4,5 , and 6 found to achieve high energy recovery and pyritic sulfur rejection.

2. To explore and develop new and promising avenues leading to effective coal surface control for selective agglomeration processes.

3. To provide support services to the DOE/PETC and other DOE contractors.

In order to achieve these objectives, research was conducted in a number of subtasks that may lead to the development of coal surface control techniques for improving the agglomeration performance. The progress during this reporting period is presented in the following.

\subsection{Quantitative Distribution of Iron Species}

The identification and quantification of iron sulfides $\left(\mathrm{FeS}_{2}, \mathrm{Fe}_{(1-x)} \mathrm{S}\right)$ and iron sulfate can be obtained using Mössbauer spectroscopy. The utilization of Mössbauer spectroscopy for characterization of iron species in coal has been demonstrated by Montano et al $^{(3-7)}$. The transmission Mossbajer spectra were obtained according to the experimental procedure discussed in the first Annual Report ${ }^{(1)}$.

Feed, product, and refuse samples of Pittsburgh \# 8 coal wet ground to 200 mesh $\times 0$ were examined. The samples were obtained from an agglomeration test conducted using $200 \mathrm{ppm}$ of tall oil added during grinding. Figures 2.1-1 through 2.1-3 show the representative curve fit spectra of the feed, product, and refuse samples. A summary of the da.a is shown in Table 2.1-1. 
For the three samples, the dominant spectral feature ws: the doublet centered about 0.60 $\mathrm{mm} / \mathrm{sec}$ corresponiting to pyrite $\left(\mathrm{FeS}_{2}\right)$. Ar. additional minor component was detected at 2.8-3.0 mm/sec, originating from either iron sulfate $\left(\mathrm{Fe}_{5} / \mathrm{SO}_{4}\right)$ or iron based clays.

The data in Table 2.1-1 indicalte that the same dirt ibution was obtained for the wet ground feed and product samples, that is, $94 \%$ of iron in the form of pyrite and the remaining $6 \%$ in the form of sulfate and iron clays. The distribution of these components is different from the refuse sample in which $90 \%$ of the iron was in the pyrite form and $10 \%$ in the form of ssifate and iron basea clays.

It is interesting to note that the fraction of iron in pyrite form was the same in the feed as in the product sample. The pyrite fraction was also approximately the same as that of t. $e$ argon preserved 28 mesh $\times 0$ sample of Pittsburgh \# 8 coal $(94.0 \%$ versus $94.2 \%$. respectively).

\subsection{Surface Functional Groups}

The objective of this analytical subtask is to monitor the functional group changes an the surface and in the bulk beneath the surface layer of the coal as a function of grinding and treatment. This was achieved by using Diffuse Reflectance Infrared Fourier Transform (DRIFT) Spectroscopy in tive same manner employed by researchers at $\mathrm{USX}^{(8)}$ and $\mathrm{CONOCO}^{(9)}$.

The oxidation index is defined as the ratio of the integrated intensity of the carbonyl band $\left(1635-1850 \mathrm{~cm}^{-1}\right)$ to that of the $\mathrm{C}-\mathrm{H}$ stretching band $\left(2746-3194 \mathrm{~cm}^{-1}\right)$ in the diffused reflectance FTIR spectrum. The limits associated with the latter area may vary slightly depending upon the baseline of the spectrum. A decrease in the $2746-3194 \mathrm{~cm}^{-1}$ band is attributed to the loss of $\mathrm{C}-\mathrm{H}$ groups by oxidation and an increase in the 1635$1850 \mathrm{~cm}^{-1}$ band to the production of carbonyl groups. Both absorption bands are related to the organic structure of coal and the ratio can provide a good indication of organic matrix oxidation. The experimental procedure, including sample preparation, data acquisition, and analysis were described in the first Annual Report ${ }^{(1)}$.

During this quarter, the : idation indices of samples ground in water were reevaluated. The new values were compared with oxidation indices of samples ground in air. The 
oxidation indices of samples obtained from aggiomeration tests conducted using surface modification reagents during or after grinding were also investigated. A discussion of the DRIFT spectroscopy results is presented below.

\subsubsection{Comparison of Wet and Dry Ground Samples}

Replicate data (the summation of 1000 scans) for 200 miesh $\times 0$ samples of Pittsburgh \# 8 and Illinois \# 6 coals were obtained. Table 2.2.1-1 and Figures 2.2.1-1 and 2.2.1-2 show a comparison between the oxidation indices of dry and wet ground samples.

The oxidation indices of samples ground in water measured during 1990 were found to be consistently higher than the indices reported earlier. This discrepancy in oxidation indices of wet ground samples is attribu+2d to different sample drying conditions. Beginning in January 1990, a standard method of drying was established. For wet ground feed coal, the samples were dried in an oven at $60^{\circ} \mathrm{C}$ for one day. In the case of product and refuse from agglomeration tests, the samples were dried for 2 days at $60^{\circ} \mathrm{C}$.

A major increase in the oxidation index for the wet ground versus the dry ground samples was observed for both coals. This indicates that the presence of water during grinding increased the number of carbonyl groups relative to the number of aromatic/aliphatic bonds. This behavior may be attributed to the drying method used for sample preparation for the DRIFT analyses.

For both Pitrsburgh \# 8 and Illinois \# 6 ccals, the feed and product samples show similar oxidation indices. The oxidation index of the Pittsburgh \# 8 refuse sample was lower, but this result may be caused by the relatively high concentration of mineral matter in the sample.

\subsubsection{Study of Illinois \#6 Coal Wet Ground Using Additives}

A comparison of oxidation indices for 200 mesh $\times 0$ wet ground Illinois \# 6 coal samples from agglomeration tests in which surface modification reagents were used during grinding or before agglomeration is shown in Figure 2.2.2-1 and Table 2.2.2-1. Two modes of addition were used: Aerosol-OT and styrene were added during grinding, whereas methanol and ethanol were added after grinding but before agglomeration.

The data show that the oxidation indices of the samples treated with alcohols were the 
same or lower than samples without any additives. The oxidation index for the feed sample groumd in the presence of Aerosol-OT showed a slightiy higher oxidation index than that of the sample ground without additives, whereas the sample ground using styrene did not show any difference. In summary, the additives employed appear to have little effect on the oxidation index.

\subsubsection{Study of Wet Grinding Using Tall Oil}

A comparison of oxidation indices for 200 mesh $\times 0$ Illinois * o coal samples wet ground in the presence of 20 and $200 \mathrm{ppm}$ of tall oil, and without the addition of reagents is shown in Figure 2.2.3-1 and in Table 2.2.3-1. The oxidation index of product and feed samples ground using $20 \mathrm{ppm}$ of tall oil were higher than those obtained for samples ground without any additives. The oxidation index of the feed sample ground using 200 ppm of tall oil was higher than the oxidation index of the sample ground without the addition of reagents. On the other hand, for the product sample of the test performed using a sample ground using $200 \mathrm{ppm}$ of tall oil, the oxidation index was lower than the product sample obtained from the test performed using a sample ground without any reagents.

A similar comparison of oxidation indices for 200 mesh $\times 0$ Pittsburgh \# 8 coal wet ground samples is shown in Figure 2.2.3-2 and Table 2.2.3-2. The oxidation index of the feed sample ground with 200 ppm of tall oil added is similar to that of the sample ground without additives. The oxidation index of the product from an agglomeration test conducted using a sample ground using $200 \mathrm{ppm}$ of tall oil was higher than that of the product sample from a test performed using a feed sample prepared with no reagents added.

The lack of clear trends among samples, and the overlapping error bars for the $95 \%$ confidence intervals (see Figures 2.2.3-1 and 2.2.3-2) suggest that there is no significant difference between the oxidation indices of samples wet ground with and without all oil. This finding was expected since the presence of tall oil at the low concentrations used did not affect the properties of the grinding medium and did not produce any oxidation of coal particles. 


\subsection{Surface Composition}

The objectives of the surface composition analysis performed using the Laser Microprobe Mass Analyzer (LAMMA) were: first, to evaluate changes in surface composition as a function of reagent addition and grinding procedure; and second, to determine changes in the elemental composition of the product and refuse compared with the feed for samples from agglomeration tests.

Surface and near surface composition analyses were performed using the Leybold Heraeus LAMMA 1000. All spectra represent the summary data for 500 individual spectra obtained from various positions on the surface. Samples were prepared and analyzed as desuribed in the first Annual Repori ${ }^{(1)}$.

As stated previous!y, the LAMMA samples the surface to a depth of approximately 1 micron providing data for surface components and the bulk near the surface. LAMMA data are given in percent total ionization. While the percent total ionization does not represent absolute concentrations, trends in the concentration caused by physical and chemical treatment can be followed. Use of the percent total ionization is a standard technique in mass spectrometry where sensitivity factors are not readily available. Changes in percent total ionization are proportional to changes in the concentration of the elements.

During this quarter, LAMMA analysis of surface and near surface composition were carried out on Pittsburgh \# 8 and Illinois \# 6 coals wet ground to 200 inesh $x 0$ with the addition of $200 \mathrm{ppm}$ of tall oil. Samples of these coals wet round without additives were also analyzed to provide base data. The results and disciusion of these analyses is presented in the following.

\subsubsection{Elemental Distribution of Coal Samples Wet Ground Without Additives}

In order to determine general trends in elemental distribution for refuse and product, percent change relative to feed was calculated for the percent tctal ionization of the elements in the product and refuse relative to feed coal. Only changes greater than $5 \%$ were considered significant. If an element's percent change increased in the product, in 
general it decreased in the refuse, and vice versa, but in some cases significant changes in only one fraction were seen. The anomalies observed are being checked.

For Pittsburgh \# $8 \mathrm{coal}$, the iron and sulfur percent total ionization decreased from feed to product and increased in the refuse. $\mathrm{Mg}, \mathrm{Li}, \mathrm{Si}$ also increased in the refuse. $\mathrm{Na}, \mathrm{Al}$, $\mathrm{Ca}$, and $\mathrm{Ti}$ segregated in the opposite fashion, increasing in the product and decreasing in the refuse. These results are shown in Table 2.3.1-1 and Figure 2.3.1-1.

For illinois \# 6 coal samples, the same general trend was observed, that is, for iron and sulfur distributing more into the refuse than into the product. Some anomalies, however, were observed for iron. Figure 2.3.1-2 shows that the iron concentration iacreased in both the product and refuse, instead of lecreasing in the product and increasing in the refuse. For Illinois \# 6 coal, $\mathrm{Na}, \mathrm{T}: \mathrm{K}$, and $\mathrm{Ca}$ distributed preferentially into the product, while $\mathrm{Li}, \mathrm{Al}, \mathrm{S}, \mathrm{Fe}, \mathrm{Mg}$, and $\mathrm{Si}$ segregated preferentially into the refuse. Table 2.3.1-2 and Figure 2.3.1-3 show these results.

\subsubsection{Elemental Distribution of Coal Samples Wet Ground With Tall Oil}

In order to determine whether the addition of tall oil during grinding had any influence on elemental composition of the feed, product, and refuse samples, LAMMA analyses were conducted. For Pittsburgh \# 8 coal wet ground with $200 \mathrm{ppm}$ of tall oil, the same trend for iron and sulfur was seen as in the samples grounu without tall oil, that is, an increase in percent total ionization in the refuse and a decrease in the product. Figures 2.3.2-1 and 2.3.2-2 illustrate these findings.

Figure 2.3.2-3 compares the results of the LAMMA analysis and the agglomeration results for Pittsburgh \# $8 \mathrm{coal}$. The feed to this tests were wet ground with $200 \mathrm{ppm}$ of tall oil and without additives. The plots reveal the excellent agreement between the trend observed for the total sulfur content obtained by standard ASTM sulfur analysis and the surface sulfur concentration of the feed, product, and refuse samples.

As seen in Table 2.3.2-1 and Figure 2.3.2-4, the Pittsburgh \# 8 samples ground with tall oil showed a slight change in elemental distribution. In this case, $\mathrm{Na}, \mathrm{Ca}, \mathrm{Al}, \mathrm{Ti}$, and $\mathrm{K}$ distributed from the feed to the product; $\mathrm{Li}, \mathrm{S}, \mathrm{Fe}$, and $\mathrm{Si}$ increased in the refuse; and Mg did not show any particular trend. 
Figure 2.3.2-5 shows that for Illinois \# 6 coal, the sulfur concentration increased in both the product and refuse samples, instead of only increasing in the refuse. The trends for elemental distribution of the product and refuse samples treated with tall oil were the same as those for untreated samples. Figure 2.3.2-6 and Table 2.3.2-2 show that $\mathrm{Na}, \mathrm{Ca}$, and $\mathrm{Ti}$ increased in the product. $\mathrm{Fe}, \mathrm{S}, \mathrm{K}, \mathrm{Mg}$, and $\mathrm{Si}$, on the other hand, showed a shift of concentration into the refuse. The addition of tall oil only changed the distribution of $\mathrm{K}$ and $\mathrm{Al}$ for Illinois \# 6 coal.

The results of the elemental analysis of particle surfaces together with morphological analysis of the particles and with electron microprobe measurements might provide a basis for future study on the phenomenon of sliming caused by adsorption of mineral matter on coal particles

\subsection{Direct Determination of Pyrite by X-ray Diffractiou}

A method of direct determination of the pyrite content of coal using $X$-ray diffraction (XRD) is currently being developed. A brief summary of the background and status of this technique is presented in the following.

When a crystalline mineral such as pyrite is irradiated by $\mathrm{X}$-rays, these $\mathrm{X}$-rays are diffracted according to Bragg's law. Thus, when a powder sample containing pyrite is placed in a diffractometer and irradiated by monochromatic X-rays (say $\operatorname{CuK} \alpha$ ), a number of peaks can be recorded for corresponding pairs of angles of incidence, $\theta_{i}$, and spacings of the atomic planes of the mineral, $d_{i}$. The pattern represents a fingerprint for that mineral and the intensity of the peaks is proportional to the amount of mineral in the sample. Therefore, it can be used for quantitative determination of pyrite.

Pittsburgh \# 8 coal samples, wet ground in the presence of styrene were used to test the method. The X-ray diffraction patterns were obtained for feed, product, and refuse samples using a XRD $700 \mathrm{GE}$ diffractometer equipped with a graphite monochromator. An internal standard of $5 \% \mathrm{MgO}$ was added to the samples. The samples were ground in a Spex mill to reduce orientation of the particles that produce undesirable peaks in the spectrum. It was found that grinding for 15 minutes maximized the $\mathrm{X}$-ray diffraction 
intensities. The ratio of the intensity of the $2.71 \AA$ line of pyrite to the $2.11 \AA$ line of $\mathrm{MgO}$ was used as a relative measure of the pyrite content.

The results of this analysis are given in Table 2.4-1, together with the results of the corresponding agglomeration test. Using the values from Table $2.4-1$, the feed weight can be estimated as $26.63 \mathrm{~g}$. If a loss of approximately $1 \mathrm{~g}$ is considered for the agglomeration test, then the difference between the feed weight calculated from the $\mathrm{XRD}$ ratios and that obtained from the agglomeration results is $2.89 \mathrm{~g}$, which means an error of $12 \%$.

In order to obtain actual values of the $p$ :rite content, an internal calibration procedure was developed. The coal samples were doped with additions of 3,5 , and $8 \%$ of mineral pyrite. The intensity of the $(200)$ line of pyrite $(d \simeq 2.71 \dot{A})$ was plotted as a function of the percentage of mineral pyrite. The extrapolation of the line passing through the three points to intensity equal to zero gave an estimate of the pyrite content in the coal sample. The initial test results were found to be in close agreement with the pyritic sulfur content measured using the ASTM method. However, the procedure must be further tested with additional samples.

This method has the advantage of determining the pyrite content of coal directly. However, a relative uncertainty in the order of $10 \%$ is expected.

\subsection{Electron Microprobe Measurements}

Electron microprobe (EPMA) measurements of surface composition were carried out using feed, product and refuse samples of Pittsburgh \# 8 coal treated with tall oil during grinding. A new sample preparation method in which the coal sample is stuck in powder form on double stick paper was utilized in thcse analyses. It is expected that this new approach will provide more representative results than those obtained using a pellet. Preliminary results confirm the expected trend for the concentrations of sulfur, iron, aluminum and silicon, that is, the refuse, feed, and product values decreasing in that order. These analyses will be repeated and compared with the results obtained by direct determination of pyrite using XR $\mathrm{X}$. A combination of these methods may provide a new approach for pyrite identification and quantification. 


\subsection{Coal Morphology}

The qualitative study of the morphology of ground coal was continued with more extensive analyses of the three base coals using SEM. Previous findings regarding the morphology of Upper Freeport, Pittsburgh \# 8, and Illinois \#6 coals were confirmed.

In general, 200 mesh $\times 0$ wet ground samples of Pittsburgh \#8 and Illinois \# 6 coals were very similar. Both coals showed a fracture with significant plasticity resulting in partial cracking of particles and many surface cracks.

Uppar Freeport coal showed cleaner fractures which result in a flaky habit of the ground coal. Its behavior is indicative of a brittler nature leading to clean cleavage and less tendency to reagglomerate in water.

The differences in morphology among the coals are mirrored in the rank of the coal (Upper Freeport coal belongs to a higher rank). They may play a role on grinding efficiency and agglomeration performance. In the presence of additives, the limited observations now available are not sufficient to draw conclusions about their effects on morphology, which depend on grinding time, the type of additive and its concentration.

\subsection{Zeta Potential Measurements}

The zeta potential of samples ground to 200 mesh $\times 0$ in the presence of light hydrocarbons were measured for the three base coals. The experimental procedure was described in the first Annual Report ${ }^{(1)}$. Table 2.7-1 shows the pH and zeta potential of samples ground using n-pentane, cyclohexane, and $n$-heptane. The data of Table 2.7-1 indicate that for Pittsburgh \#8 and Illinois \#6 coals the addition of these hydrocarbons shifted the zeta potential toward the isoelectric point. For Upper Freeport coal, however, no clear trend was observed. 


\subsection{Pyrite Size Distribution}

As a part of the petrographic characterization of coal carried out in Task 3, pyritic mineral mistter was analyzed microscopically in terms of frequency distribution by size and association. 28 mesh $\times 0$ and 200 mesh $\times 0$ samples of Upper Freeport, Pittsburgh \# 8 , and Illinois \# 6 coals were studied and the results were reported in the first Annual $\operatorname{Report}^{(1)}$.

Each pyrite particle measured by the microscope was classified into one of the three categories of association: locked, semi-locked, and free. Locked pyrite is completely surrounded by coal while semi-locked pyrite is partially surrounded by coal. A free pyrite particle contains no observable coal.

The frequency distributions by size of the pyrite particles reported in the first Annual Report were obtained from two-dimensional images of polished coal samples. In order to obtain a more useful representation of the pyrite size distribution it is desirable to have a three-dimensional frequency distribution of particle size. The three-dimensional frequency distribution can then be used to obtain a volume percent distribution as a function of pyrite particle size.

The problem of determining spatial size distributions from two-dimensional measurements was discussed by Underwood ${ }^{(10)}$. In general, the analyses are based on the assumptions that: (a) the particles are spherical; and (b) the distribution of particle sizes can be represented by a discontinuous distribution.

Appendix $\mathrm{C}$ describes the procedure for generating a three-dimensional size distribution from a two-dimensional size distribution that satisfies the assumptions mentioned above. A computer program, also listed in Appendix C, was written in BASIC in order to perform this procedure.

Tables 2.8-1 through 2.8-6 show the results obtained for the three base coals. For some of the 3-D frequency and volume distribution p'scentages, negative results were obtained due to inaccurate statistics in the two-dimensional distribution (see Appendix C). Because the particle size range studied is very wide (especially for 28 mesh $\times 0$ 
samples), the number of particles counted must be sufficiently large in order to obtain a statistically acceptable histogram of number frequency versus diameter.

A comparison of the volume distribution data for 28 mesh $\times 0$ and 200 mesh $\times 0$ pyrite particles reveals the importance of grinding for pyrite liberation. Figure 2.8-1 and 2.02 show the association characteristics of pyrite particles for the 28 mesh $\times 0$ and the 200 mesh $x 0$ samples, respectively. For Upper Freeport and Pittsburgh \# 8 coals, the data indicate that a significant reduction in the amount of locked and semi-locked pyrite occurs when the sampli: is ground finer.

For Illinois \# 6 coal, however, the data do not support the same finding. This coal may contain two types of pyrite particles: large ( $>600$ microns) and small ( $<75$ microns). The larger oules can be easily liberated at the 28 mesh $\times 0$ grinding level while the smaller particles ( $<75$ microns) can not be liberated even at the 200 mesh $\times 0$ grinding level.

\subsection{Statistical Analysis of Grinding Study Data}

Follow-up agglomeration tests were conducted to complete and verify the results of the grinding studies performed in Task 5. The effects of particle size, grinding method, slurry concentration, pentane to coal ratio (PCR), agglomeration time, and mixing speed on the agglomeration performance were studied. In order to minimize the number of experiments, the tests were arranged in a two-level factorial design. Table $2.9-1$ lists the experimental conditions used in these tests.

The Analysis of Variance (ANOVA) of the energy recovery and ash rejection data was performed for the three coals. Single variables and double interactions of variables were considered in the analysis. The commercial software package, Number Cruncher Statistical System (NCSS) ${ }^{(11)}$, was used to carry out the statistical analysis.

Tables 2.9-2 and 2.9-3 summarize the results of the analysis of variance for energy recovery and ash rejection for Upper Freeport, Pittsburgh \# 8, and Illinois \# 6 coals. Each entry lists the coals that satisfied the condition that a variable or interaction had a probability higher than 0.95 of having an effect on the response variable. Tables 2.9-4 and 2.9-5 show the average values of energy recovery and ash rejection for the variables 
and interactions that had a statistically significant effect on the response variable for at least two coals.

The analysis of variance and the comparison of the results for different conditions clearly indicates that particle size and grinding method were the most important variables affecting the performance of the agglomeration process. Figures $2.9-1$ and 2.9-2 depict sc..ematically the effects of the grinding method and particlo size on energy recovery and ash rejection.

The data in Tables 2.9-2 and 2.9-4 also show that the particle size of the sample had the most statistically significant effect on energy recovery. For the three coals, finer particle size resulted in higher energy recoveries. The effeci increased as the coal rank decreased since the differences between the energy recoveries obtained for 200 mesh $\times 0$ and 28 mesh $\times 0$ samples were 7, 27, and 39 percentage points for Upper Freeport, Pittsburgh \# 8, and Illinois \#6 coals, respectively.

The thermodynamic analysis of the selective agglomeration process by Jacques et al. ${ }^{(12)}$ and Keller and Burry ${ }^{(13)}$ suggests that an oil droplet coats the surface of a coal particle more easily as the relative size of the oil droplet to the coal particle increases. Therefore, the higher energy recovery obtained with finer particle size may be due to the increase in the relative size of oil droplets with finer particle size.

Tabies 2.9-2 and 2.9-4 show that for both Illinois \# 6 and Pittsburgh \# 8 cjais, wet grinding improved the energy recovery of 200 mesh $\times 0$ coals, but had a detrimental effect on the energy recovery of 28 mesh $\times 0$ coals. An opposite behavior was observed for Upper Freeport coal, where a slight improvement of the energy recovery of 28 mesh $x 0$ coal and a slight decrease in the energy recovery of 200 mesh $x 0$ coal were observed.

Whereas the effect of wet grinding on energy recovery was beneficial or detrimental depending on particle size and coal type, the effect of wet grinding on ash rejection was beneficial for the three coals studied as can be sean in Table 2.9-5. A significant improvement that ranges between 13 and 25 percentage points was observed when the samples were wet ground when compared with those dry ground.

The improvement in ash rejection due to wet grinding was much more pronounced with 200 mesh $\times 0$ than with 28 mesh $\times 0$ coal particles. This may be attributed to the fact that more mineral matter was liberated with finer particles. Our data, on the other 
hand, showed that with dry grinding, the ash rejection for the 28 mesh $\times 0$ samples was significantly higher than that for the 200 mesh $\times 0$ sampies. As a matter of fact, dry grinding to 200 mesh $\times 0$ yielded the worst ash rejection in all cases. For the three coals studied, the ash rejection was at least 24 percentage points lower than the average of the tests. This behavior may be attributed to the fact that the liberated ash forming materials during dry fine grinding (200 mesh $\times 0$ ) adhere and/or are entrapped more easily with clean coal agglomerates than the ash forming unaterials obtained from dry coarse grinding ( 28 mesh $\times 0)$.

The combination of the improvement in ash rejection due to wet grinding and the improvement in energy recovery due to finer grinding led to the conclusion that wet grinding to 200 mesh $\times 0$ was the mos: beneficial size reduction procedure for the present agglomeration process.

Slurry concentration had statistically significant effects on performance for all three coals. However, the effects on energy recovery and ash rejection were at most in the order of three to six percentage points. Table 2.9-5 shows that the decrease in ash rejection at finer size was more significant at the higher slurry concentration for Illinois \# 6 and Pittsburgh \# 8 coals. This table also shows that when the slurry concentration was increased from 2 to $4 \mathrm{wt} . \%$, ash rejections for the three coals decreased significantly. This can be attributed to the increased entrapment of ash-forming materials into the agglomerates formed at higher coal concentration. However, as Table 2.9-4 shows, the energy recovery increased or decreased depending on the coal type. As the slurry concentration was increased from 2 to $4 \mathrm{wt} . \%$, the energy recovery for Illinois \# 6 and Upper Freeport coals increased, but the energy recovery for Pittsburgh \# 8 decreased.

The pentane to coal ratio also had a significant effect on energy recovery and ash rejection for the three coals used. Table 2.9-4 shows that as the PCR increased, the energy recovery increased. However, the increased recovery was accompanied by increased entrapment of ash-forming materials into the agglomerates. As a result, ash rejection decreased with higher PCR (see Table 2.9-5).

In general, agglomeration time and mixing speed did not have a statistically significant effect on agglomeration performance. This finding may be due to the narrow range used for these two variables. 


\subsection{Grinding Using Ligh $!$ Hydrocarbons}

Follow-up agglomeration tests were conducted using light hydrocarbons during grinding. The new results were combined with previous data to conduct statistical analyses of the efíect of the hydrocarbon to coal ratio on agglomeration performance. $\mathrm{N}$-pentane, cyclohexane, and $n$-heptane were added before wet grinding to 200 mesh $\times 0$ according to the experimental procedure described in the in the irst Annual Report ${ }^{(1)}$. Tables 2.10-1 through 2.10-3 show the average energy recoveries, ash and pyritic sulfur rejections for Upper Freeport, Pittsburgh \# 8, and Illinois \# 6 coals. Appendix D lists the detailed results of these experianents.

The effect of the addition of hydrocarbons on energy recovery, ash and pyritic sulfur rejections was statistically evaluated. The commercial software package, Number Cruncher Statistical System (NCSS) ${ }^{(4)}$, was used to carry out the analysis. A total of 110 agglomeration tests were conducted in this study. The entire set of data was utilized to determine the standard deviation within replicates for the t-tests. Table 2.10-4 shows the values of the standard deviation for the response variables, energy recovery (BTU), ash rejection (ARJ), and pyritic sulfur rejection (PSRJ). These values were used as a basis to evaluate the specific effects of the addition of each light hydrocarbon during grinding.

\subsubsection{Effects of $\mathrm{N}$-pentane}

For the three coals studied, the addition of $n$-pentane during grinding resulted in lower ash and pyritic sulfur rejections. The energy recovery, on the other hand, increased slightly ( $4 \%$ at most) for Pittsburgh \#8 and Illinois \# 6 coals. For Upper Freeport coal, energy recoveries larger than $99.5 \%$ were obtained in all cases.

For Upper Freeport coal, the addition of n-pentane promoted particle aggregation during grinding which resulted in the agglomeration of clean coal particles as well as mineral matter including pyritic sulfur. Consequently, as Figure 2.10.1-1 shows, the ash and pyritic sulfur rejections decreased as the reagent to coal ratio (RCR) increased. Table 2.10.1-1 shows that at a RCR of $1 / 100$, this effect was not statistically significant, but at a RCR of $1 / 10$ the decrease in ash rejection was statistically significant. At higher RCRs, a cake formed during grinding that prevented the completion of the sample preparation. 
Table 2.10.1-1 indicates that the effects of the addition of $n$-pentane during grinding on the agglomeration performance for Pittsburgh \# 8 did not have any statistical significance.

For Illinois 6 coal, the addition of $n$-pentane at the lowest RCR of $1 / 20$ had a major effect on agglomeration performance. Table 2.10.1-1 shows that a statistically significant increase in energy recovery and a decrease in ash and pyritic sulfur rejection were observed. At higher RCR, this effect decreased, becoming statistically insignificant at a RCR of $1 / 2$. This behavior is illustrated in Figure 2.10.1-2.

\subsubsection{Efferts of Cyclohexane}

Table 2.10.2-1 shows that for Upper Freeport and Illinois \# 6 coals, the addition of cyclohexane did not have any significant effects on agglomeration performance. For Upper Freeport coal, grinding using cyclohexane was only possible at a RCR of 1/100. At higher R.CRs, the formation of a cake in the ball mill prevented grinding of the samples.

Table 2.10.2-1 also shows that for Pittsburgh \# 8 coal the addition of cyclohexane during grinding had a statistically significant effect on ash rejection. Figure 2.10.2-1 shows that as RCR increased, ash rejection decreased. It is believed that agglomeration during grinding caused entrapment of mineral particles and therefore a raduction in ash rejection. At a $R C R$ of $1 / 5$, this effect became so strong that a cake formed in the ball mill and it was not possible to complete grinding of the sample.

\subsubsection{Effects of $\mathbf{N}$-heptane}

For Upper Freeport coal, grinding in the presence of $n$-heptane was only possible at a RCR of 1,100. At higher RCRs, the formation of a cake in the stirred ball mill prevented the completion of the grinding operation. Table 2.10.3-1 shows that no significant effect of the addition of n-hiptane on agglomeration performance was observed.

Figure 2.10.3 $\cdots 1$ shows that for Pittsburgh \# 8 coal, the addition of $n$-heptane resulted in increases in energy recovery, as well as decreases in ash and pyritic sulfur rejection. Table 2.10.3-1 shows that these effects were statistically significant at RCRs of $1 / 20$ and 
1/10. At a RCR of $1 / 50$, the effects were smaller. At a $R C R$ of $1 / 5$, grinding was not possible because of cake formation in the ball mill.

For Illinois \# 6 coal, Table $2.10 .3-1$ shows that the only statistically significant effect of the addition of $\mathrm{n}$-heptane during grinding was a reduction in energy recovery at a $\mathrm{RCR}$ of $1 / 2$.

\subsection{Optimization of the Agglomeration Process}

The study of the agglomeration process using $n$-pentane as the agglomerant was continued by performing several series of tests in which the effects of different feed preparation procedures and operation variables on agglomeration performance were investigated. Acpendix $\mathrm{E}$ lists the detailed results of these tests. The analysis of the results is presented in the following.

\subsubsection{Study of the Effects of the Grinding Method}

The effect of grinding method on agglomeration performance was studied using, Pittsburgh \# 8 coal. Coal samples were ground for $15 \mathrm{~min}$ in the stirred ball mill and for 20 hours in the ceramic jar $1 ., 1$. The average volume particle size, $d_{60}$, of both samples was about the same within the experimental error of Microtrac measurements. Three mixing times were used in each case: 15, 30, and 60 seconds. The average energy recovery, ash and pyritic sulfur rejections of these tests are plotted in Figures $2.11 .1-1$ through 2.11.1-3. These figures show that lower encrgy recoveries, ash and pyritic sulfur rejections were obtained for the samples ground in the jar mill for 20 hours. Grinding in the jar mill for 20 hcurs was particularly detrimental to the energy recovery, which was on the average 1 s percentage points lower than that obtained for the samples ground in the ball mill. This behavior may be attributed to excessive hydration of the coal particles due to the longer grinding time in the ceramic jar mill.

\subsubsection{Study of the Effects of the Grinding Time}

The effect of grinding time on agglomeration performance was studied using Pittsburgh \# 8 coal. Pulverized roal samples were wet ground in the stirred ball mill for 15, 20, 
25, and 30 minutes. Agglomeration tests were conducted utilizing a n-pentane to coal ratio of 0.5 .

The particle size distribution of the feed samples is depicted in Figure 2.11.2-1. It can be observed that, as expected, the average particle size, $d_{50}$, decreases for longer grinding time.

Figures 2.11.2-2 and 2.11.2-3 show the energy recovery and ash rejection results, respectively. A significant decrease in ash rejection was observed as grinding time increased. The highest energy recovery was obtained for a grinding time of 15 minutes. However, although longer grinding time resulted in a slightly lower energy recovery, no trend such as that observed for the ash rejection was apparent. The comparison of the agglomeration test data shows that the best agglomeration performance was obtained for the shortest grinding time used, that is, $15 \mathrm{~min}$.

\subsubsection{Study of the Effects of the Agglomeration Time}

The effect of agglomeration time on agglomeration performance was studied usir; 200 mesh $x 0$ wet ground samples of Upper Freeport, Pittsburgh \# 8, and Illinois \# 6 coals. The results of these tests are show in Figures 2.11.3-1 through 2.11.3-3. The tests were conducted using a slurry concentration of $2 \%$ and a pentane to coal ratio of 0.5 .

Figure 2.11.3-1 shows that for Upper Freeport and Pittsburgh \# 8 coals, an agglomeration time of 60 seconds was sufficient to attain an energy recovery close to $100 \%$. For Illinois \# 6, however, a longer time may be needed since for an agglomeration time of 60 seconds the energy recovery was only $70 \%$.

In terms of ash rejection (Figure 2.11.3-2), for Pittsburgh \#8 and Illinois \# 6 coals, no effect was observed for agglomeration times longer than 30 seconds. For Upper Freeport coal, however, ash rejection decreased as agglomeration time increased.

The results shown in Figure 2.11.3-3 indicate that agglomeration time did not have any significant effect on pyritic sulfur rejection in the range studied.

Further study of the effect of agglomeration time on agglomeration performance will be conducted using longer agglomeration times for Illinois \# 6 coal. For Upper Freeport and Pittsburgh \# 8 coals, 60 seconds can be considered the optimum agglomeration time in terms of energy recovery within the range of experimental conditions used. 


\subsubsection{Study of the Effects of the Pentane to Coal Ratio}

A study of the effects of pentane to coal ratio (PCR) on agglomeration performance was conducted. Figures 2.11.4-1 through 2.11.4-3 show the average energy recovery, ash and pyritic sulfur rejections obtained at two pentane to coal ratios $(0.5$ and 1.5$)$ and three agglomeration times $(15,30$ and 60 seconds). Figure 2.11.4-1 shows that for a short agglomeration time, a higher pentane to coal ratio resulted in a significant increase on the energy recovery. This effect, however, decreased for longer agglomeration times, becoming neglegible for an agglomeration time of 60 seconds. For the ash and pyritic sulfur rejections, on the other hand, no trend relating the pentane to coal ratio and agglomeration time was observed. 


\subsection{CONCLUSIONS}

A summary of the most important conclusions obtained in this quarter is presented in the following.

Several analytical techniques developed in Task 3 were utilized during this quarter to analyze samples from the agglomeration tests performed using $n$-pentane as agglomerant.

- For Pittsburgh \# 8 coal wet ground to 200 mesh x 0 with 200 ppm of tall oil, the product and feed samples from agglomeration tests using $n$-pentane as agglomerant showed the same fraction of iron in the form of pyrite. For the refuse sample, a major increase in the fraction of iron in the orm of sulfate/clays was observed.

- Oxidation indices were higher for wet ground samples than for dry ground samples of both Pittsburgh \# 8 and Illinois \# 6 coal ground to 200 mesh $\times 0$.

- The use of additives during grinding or before the agglomeration tests did not have any significant effect on the oxidation index of feed and product samples of Illinois \# 6 coal.

- For Pittsburgh \#8 and Illinois \# 6 coals wet ground to 200 mesh $\times 0$ with and without tall oil added, LAMMA analysis reveals that the surface concentration of sulfur and iron increased in the refuse relative to the feed.

- For most samples from agglomeration tests, $\mathrm{Mg}, \mathrm{Li}, \mathrm{Si}, \mathrm{S}$, and $\mathrm{Fe}$ showed increased surface concentration in the refuse relative to the feed. In the case of the product, $\mathrm{Na}, \mathrm{Ca}$, and $\mathrm{Ti}$ showed increased concentration relative to the feed.

- SEM analyses of the morphology of 200 mesh $\times 0$ wet ground samples of Pittsburgh \# 8 and Illinois \# 6 coals showed a fracture with a plasticity resulting in partial cracking of particles and many surface cracks. Upper Freeport coal samples showed cleaner fractures which result in a flaky habit of the ground coal. 
- The zeta potential measurements of samples ground to 200 mesh $x 0$ in the presence of light hydrocarbons indicate that for Pittsburgh \# 8 and Illinois \#6 coals the addition of these hydrocarbons shifted the zeta potential toward the isoelectric point. For Upper Freeport coal, however, no clear trend was observed.

- The comparison of the volume distribution data for 28 mesh $\times 0$ and 200 mesh $\times$ 0 pyrite particles for Upper Freeport and Pittsburgh \# 8 coals indicates that a significant reduction in the amount of locked and semi-locked pyrite occurs when the sample is ground finer.

Agglomeration tests were performed using both dry and wet ground coals. The statistical significance of the effects of process variables on agglomeration performance were determined. The results showed that interactions between variables as well as their main effects were important.

- The coal particle size had the most statistically significant effect on energy recovery whereas the grinding method had the most pronounced effect on ash rejection. The analysis of the interaction between particle size and grinding method indicated that wet grinding to 200 mesh $\times 0$ resulted in the best performance for the three coals studied.

- Minor effects (although statistically significant) of the slurry concentration and n-pentane to coal ratio on ash rejection were observed for the three coals studied. In general a lower slurry concentration and a lower PCR increased ash rejection.

Follow up agglomeration tests were conducted using $\mathrm{N}$-pentane, cyclohexane, and $\mathrm{n}$ heptane added during wet grinding to 200 mesh $\times 0$. The new results were combined with previous data by using statistical analyses to asses the effect of the indrocarbon to coal ratio on agglomeration performance.

- For Upper Freeport coal, the addition of n-pentane promoted particle aggregation during grinding which caused the ash and pyritic sulfur rejections to decrease as the reagent to coal ratio increased. 
- For lllinois \#6 coal, a statistically significant increase in energy recovery and a decrease in ash and pyritic sulfur rejection were observed for a $n$-pentane to coal ratio of $1 / 20$. At higher ratios, this effect decreased, becoming statistically insignificant at a $n$-pentane to coal ratio of $1 / 2$.

- For Pittsburgh \# 8 coal, the addition of cyclohexane during grinding had a statistically significant effect on ash rejection. As the cyclohexane to coal ratio increased, ash rejection decreased.

- For Pittsburgh \# 8 coal, the addition of $n$-heptane resulted in increases in energy recovery, as well as decreases in ash and pyritic sulfur rejection. These effects were statistically significant at $n$-heptane to coal ratios of $1 / 20$ and $1 / 10$. At a ratio of $1 / 50$, the effects were smaller and at a ratio of $1 / 5$, grinding was not possible because of cake formation in the ball mill.

The optimization of the agglomeration process using $n$-pentane as the agglomerant was continued by performing several series of tests in which the effects of different feed preparation procedures and operation variables on the agglomeration performance were investigated.

- Lower energy recoveries, ash and pyritic sulfur rejections were obtained for Pittsburgh \# 8 coal samples ground for 20 hours in the ceramic jar mill compared with those ground for $15 \mathrm{~min}$ in the stirred ball mill.

- For Pittsburgh \# 8 coal wet ground in the stirred ball mill for intervals ranging between 15 and 30 minutes, the best agglomeration performance was obtained for a grinding time of $15 \mathrm{~min}$.

- For Upper Freeport and Pittsburgh \# 8 coals, an agglomeration time of 60 seconds was sufficient to attain an energy recovery close to $100 \%$. For Illinois \# 6 , however, a longer time may be needed since for an agglomeration time of 60 seconds the energy recovery was only $70 \%$.

- For Pittsburgh \# 8 and Illinois \# 6 coals, no effect on ash rejection was observed for agglomeration times longer than 30 seconds. For Upper Freeport coal, however, ash rejection decreased as agglomeration time increased. 
- Agglomeration tests conducted at pentane to coal ratios of 0.5 and 1.5 using Pittsburgh \# 8 coal indicate that for agglomeration times up to 30 seconds, a higher pentane to coal ratio resulted in a significant increase in the energy recovery. This effect, however, decreased for longer agglomeration times, becoming neglegible for an agglomeration time of 60 seconds. 


\subsection{WORK SCHEDULE AND PLAN}

The work schedule is shown in Figure 4.0-1. The darkened bars indicate the completed portions of each task, and the empty bars refer to the scheduled future work. The research work on Task 7 will be continued according to the following research subtasks:

1. Optimization of the standard agglomeration test.

2. Grinding with new surface modification reagents.

3. Improved analytical methods for functional groups and pyritic/sulfatic iron species.

4. Mineralogical analysis of clays in coals.

5. Fracture and morphology of ground coal.

6. Surface area of coal using $\mathrm{CO}_{2}$ and $\mathrm{N}_{2}$.

7. Study of agglomeration kinetics.

8. Dynamic wettability behavior.

9. Pyrite depression.

10. Support services.

11. Additional agglomeration tests with the three base coals.

In the coming quarter, efforts will be focused on the following tasks:

1. Study the effect of agglomeration time on the agglomeration performance for Illinois \#6 coal for times longer than 60 seconds.

2. Initiate agglomeration tests using $\mathbf{n}$-heptane as agglomerant.

3. Contact angle measurements of $n$-pentane and $n$-heptane drops on coal pellets.

4. Study the effect of $\mathrm{pH}$ on agglomeration performance.

5. Improve the technique for direct measurement of pyrite using XRD. 


\subsection{REFERENCES}

1. Morsi, et. al., Coal Surface Control for Advanced Physical Fine Coal Cleaning Technologies, Annual Report, DOE Contract No. DE-AC22-88PC88877, September 19, 1988 - December 31, 1989.

2. Morsi, et. al., Coal Surface Control for Advanced Physical Fine Coal Cleaning Technologies, Project Work Plan, DOE Contract No. DE-AC22-88PC88877, October 24, 1988.

3. Montano, P.A., Coal Structure, ACS, Washington, DC, 192, Ch. 22.

4. Montano, P. A., Mossbauer Spectroscopy and Its Chemical Applications, A.CS, Washington, DC, 194, 1981.

5. Montano, P.A. and Bommannavar, A.S., J. Mol. Catal., 20, pp. 393-403, 1983.

6. Montano, P.A. and Bommannavar, A.S., Fuel, 61, pp. 1288-1290, 1982.

7. Montano, P.A. and Bommannavar, A.S., Fuel, 61, pp. 523-528, 1982.

8. Fuller, E. L. Jr. and Smyrl, N. R., Fuel, 64, p. 1134, 1985.

9. Wu, M. M., Robbins, G. A., Winschel, R. A. and Burke, F. P., Energy \& Fuel, 2, 2, p. $150,1988$.

10. Underwood, E. E., Quantitative Stereology, (Reading, MA: Addison Wesley Publishing Co., 1970), Chapter 5, pp. 109-17.

11. Hintze, J. L., "Number Cruncher Statistical System, version 5.3 - Power Pack, Reference Manual," 865 East 400 North, Kaysville, Utah 84037, 1988.

12. Jacques, M. T., Hovarongkura, A., and Henry Jr., J. D., "Feasibility of Separation Process in Liquid-Liquid-Solid Systems: Free Energy and Stability Analysis," AIChE Journal, Vol. 25, pp. 100-107, 1979.

13. Keller, D. V., and Burry, W., "An Investigation of a Separation Process Involving Liquid-Water-Coal Systems," Colloids and Surfaces, Vol. 22, pp. 37×50, 1987. 
APPENDIX A: TABLES 
Table 2.1-1 Mössbauer Spectroscopy Results

Pittsburgh \# 8 Coøl, Wet Ground to 200 mesh $\times 0$ with 200 ppm of Tall Oil

\begin{tabular}{lcc}
\hline & \multicolumn{2}{c}{ Percentage of Iron as } \\
Sample & Pyrite & Sulfate/Clays \\
\hline Feed & 94 & 6 \\
Product & 94 & 6 \\
Refuse & 90 & 10 \\
\hline
\end{tabular}


Table 2.2.1-1 Oxidation Indices and 95\% Confidence Intervals for Illinois \# 6 and Pittsburgh \# 8 Coals Ground to 200 mesh $x 0$ in Air and Water

\begin{tabular}{lcc}
\hline SAMPLE & Oxidation Index & $\begin{array}{c}\text { No. of } \\
\text { Runs }\end{array}$ \\
\hline Illinois \# 6 Coal & & \\
Feed, Air Ground & $1.60 \pm 0.09$ & 22 \\
Feed, Wet Ground & $2.25 \pm 0.21$ & 27 \\
Product, Wet Ground & $2.24 \pm 0.11$ & 30 \\
\hline Pittsburgh \# 8 Coal & & \\
Feed, Air Ground & $1.08 \pm 0.14$ & 28 \\
Feed, Wet Ground & $1.43 \pm 0.17$ & 16 \\
Product, Wet Ground & $1.51 \pm 0.17$ & 12 \\
Refuse, Wet Ground & $1.17 \pm 0.14$ & 4 \\
\hline
\end{tabular}


Table 2.2.2-1 Oxidation Indices and 95\% Confidence Intervals for Illinois \# 6 Wet Ground to 200 mesh x 0 with Various Additives

\begin{tabular}{lcc}
\hline SAMPLE & Oxidation Index & $\begin{array}{c}\text { No. of } \\
\text { Runs }\end{array}$ \\
\hline Illinois \# 6 Coal & & \\
Feed, Wet Ground & $2.25 \pm 0.21$ & 27 \\
Product, Wet Ground & $2.24 \pm 0.11$ & 30 \\
Feed, 20 ppm Ethanol & $1.71 \pm 0.25$ & 8 \\
Product, 20 ppm. Ethanol & $1.81 \pm 0.25$ & 8 \\
Feed, 20 ppm Methanol & $1.88 \pm 0.19$ & 8 \\
Product, 20 ppm Methanol & $2.07 \pm 0.23$ & 8 \\
Feed, 20 ppm Styrene & $1.97 \pm 0.29$ & 4 \\
Feed, 200 ppm Styrene & $2.21 \pm 0.15$ & 4 \\
Feed, 80 ppm Aerosol-OT & $2.39 \pm 0.15$ & 4 \\
\hline
\end{tabular}


Table: 2.2.3-1 Oxidation Indices and 95\% Confidence Intervals for Illinois \# 6 and Pittsburgh \# 8 Coals Wet Ground to 200 mesh $x 0$ with Tall Oil Added

\begin{tabular}{lcc}
\hline SiAMPLE & Oxidation Index & $\begin{array}{c}\text { No. of } \\
\text { Runs }\end{array}$ \\
\hline Illinois \# 6 Coal & & \\
Feed, Wet Ground & $2.25 \pm 0.21$ & 27 \\
Product, Wet Ground & $2.24 \pm 0.11$ & 30 \\
Feed, 200 ppm Tall Oil & $2.15 \pm 0.47$ & 11 \\
Product, 200 ppm Tall Oil & $1.83 \pm 0.51$ & 12 \\
Fieed, 20 ppm Tall Oil & $2.74 \pm 0.24$ & 12 \\
Product, 20 ppm Tall Oil & $2.54 \pm 0.24$ & 16 \\
\hline Pittsburgh \# 8 Coal & & \\
Feed, Wet Ground & $1.43 \pm 0.17$ & 16 \\
Product, Wet Ground & $1.51 \pm 0.17$ & 12 \\
Feed, 200 ppm Tall Oil & $1.42 \pm 0.32$ & 8 \\
Proriuct, 200 ppm Tall Oil & $1.29 \pm 0.23$ & 8 \\
Refuse, 200 ppm Tall Oil & $1.79 \pm 0.21$ & 4 \\
\hline
\end{tabular}


Table 2.3.1-1 Change in Surface Elemental Composition Relative to Feed for Pittsburgh \# 8 Wet Ground Without Additives

\begin{tabular}{lll}
\hline SAMPLE & $\begin{array}{c}\text { Elements } \\
\text { Increasing }\end{array}$ & $\begin{array}{c}\text { Elements } \\
\text { Decreasing }\end{array}$ \\
\hline Product & $\mathrm{Na} \mathrm{Al} \mathrm{Ca}$ & $\mathrm{Li} \mathrm{Mg} \mathrm{Si}$ \\
\hline Refuse & $\mathrm{Ti}$ & $\mathrm{S} \mathrm{Fe}$ \\
& $\mathrm{Mg} \mathrm{Si} \mathrm{S}$ & $\mathrm{Na} \mathrm{Al} \mathrm{K}$ \\
& $\mathrm{Fe}$ & $\mathrm{Ca} \mathrm{Ti}$ \\
\hline
\end{tabular}


Table 2.3.1-2 Change in surface Elemental Composition Relative to Feed for Illinois \# 6 Wet Ground Without Additives

\begin{tabular}{lll}
\hline SAMPLE & $\begin{array}{c}\text { Elements } \\
\text { Increasing }\end{array}$ & $\begin{array}{c}\text { Elements } \\
\text { Decreasing }\end{array}$ \\
\hline Product & $\mathrm{Na} \mathrm{Ti}$ & $\mathrm{Li} \mathrm{Al} \mathrm{S}$ \\
\hline \multirow{2}{*}{ Refuse } & $\mathrm{Li} \mathrm{Mg} \mathrm{Al}$ & $\mathrm{K} \mathrm{Ca}$ \\
& $\mathrm{Si} \mathrm{S} \mathrm{Fe}$ & \\
\hline
\end{tabular}


Table 2.3.2-1 Change in Surface Elemental Composition Relative to Feed for Pittsburgh \# 8 Wet Ground With 200 ppm of Tall Oil

\begin{tabular}{lll}
\hline SAMPLE & $\begin{array}{c}\text { Elements } \\
\text { Increasing }\end{array}$ & $\begin{array}{c}\text { Elements } \\
\text { Decreasing }\end{array}$ \\
\hline Product & $\mathrm{Na} \mathrm{Ti} \mathrm{Ca}$ & $\mathrm{Li} \mathrm{Si} \mathrm{S}$ \\
& & $\mathrm{Fe}$ \\
\hline Refuse & $\mathrm{Li} \mathrm{Si} \mathrm{S}$ & $\mathrm{Na} \mathrm{Al} \mathrm{K}$ \\
& $\mathrm{Fe}$ & $\mathrm{Ca} \mathrm{Ti}$ \\
\hline
\end{tabular}


Table 2.3.2-2 Change in Surface Elemental Composition Relative to Feed for Illinois \# 6 Wet Ground With 200 ppm of Tall Oil

\begin{tabular}{lll}
\hline SAMPLE & $\begin{array}{c}\text { Elements } \\
\text { Increasing }\end{array}$ & $\begin{array}{c}\text { Elements } \\
\text { Decreasing }\end{array}$ \\
\hline Product & $\mathrm{Na} \mathrm{Ca} \mathrm{Ti}$ & $\mathrm{Li} \mathrm{K} \mathrm{Fe}$ \\
\hline Refuse & $\mathrm{Mg} \mathrm{Si} \mathrm{S}$ & $\mathrm{Na} \mathrm{Ca}$ \\
& $\mathrm{Fe}$ & \\
\hline
\end{tabular}


Table 2.4-1 XRD Pyrite Determination Results

\begin{tabular}{lcc}
\hline Sample & XRD Ratio & $\begin{array}{c}\text { Sample } \\
\text { Weight, g }\end{array}$ \\
\hline Product & 0.306 & 17.07 \\
Refuse & 0.995 & 5.67 \\
Feed & 0.408 & \\
\hline
\end{tabular}


Table 2.7-1 Zeta Potential of Agglomeration Test Feed Samples

\begin{tabular}{llccr}
\hline Coal & Reagent & RCR & pH & $\begin{array}{c}\text { Zeta } \\
\text { Potential } \\
(\mathbf{m V})\end{array}$ \\
\hline Upper & None & 0 & 4.4 & +9.4 \\
Freeport & N-pentane & $1 / 100$ & 5.0 & +16.9 \\
& N-heptane & $1 / 100$ & 5.0 & 0.0 \\
& Cyclohexane & $1 / 100$ & 5.1 & 0.0 \\
\hline \multirow{3}{*}{ Pittsburgh } & None & 0 & 4.6 & +14.8 \\
\# 8 & N-heptane & $1 / 50$ & 5.0 & +5.5 \\
& N-heptane & $1 / 20$ & 5.0 & 0.0 \\
& Cyclohexane & $1 / 50$ & 5.0 & +11.0 \\
\hline & None & 0 & 4.6 & -20.4 \\
& N-pentane & $1 / 20$ & 5.3 & -18.8 \\
& N-pentane & $1 / 10$ & 5.2 & -14.6 \\
& N-pentane & $1 / 5$ & 5.3 & -16.2 \\
& N-pentane & $1 / 2$ & 5.2 & -12.9 \\
& N-heptane & $1 / 2$ & 5.1 & -16.7 \\
& Cyclohexane & $1 / 20$ & 5.3 & -11.8 \\
\hline
\end{tabular}


Table 2.8-1 Pyrite Size Distribution for 28 mesh x 0 Upper Freeport Coal

\begin{tabular}{|c|c|c|c|}
\hline $\begin{array}{l}\text { Size, } \\
\text { micron }\end{array}$ & $\begin{array}{l}\text { 2-D Frequency } \\
\text { Distribution, } x\end{array}$ & $\begin{array}{l}\text { 3-D Frequency } \\
\text { Distribution, } x \\
\end{array}$ & $\begin{array}{c}\text { Volume } \\
\text { Distribution, } x \\
\end{array}$ \\
\hline \multicolumn{4}{|l|}{ Locked } \\
\hline $\begin{array}{r}2.0 \\
4.0 \\
6.0 \\
8.0 \\
10.0 \\
12.0 \\
14.0 \\
16.0 \\
24.0 \\
26.0 \\
28.0 \\
30.0 \\
32.0 \\
38.0\end{array}$ & $\begin{array}{r}16.60 \\
12.40 \\
6.60 \\
2.90 \\
1.00 \\
0.50 \\
0.30 \\
0.30 \\
0.30 \\
0.30 \\
0.30 \\
0.30 \\
0.30 \\
0.30\end{array}$ & \begin{tabular}{r}
25.18 \\
10.50 \\
4.36 \\
1.64 \\
0.45 \\
0.18 \\
0.08 \\
0.11 \\
\hdashline .0 \\
0.04 \\
0.04 \\
0.05 \\
0.08 \\
0.05
\end{tabular} & $\begin{array}{l}0.28 \\
0.95 \\
1.33 \\
1.19 \\
0.63 \\
0.44 \\
0.30 \\
0.62 \\
\ldots . .5 \\
1.02 \\
1.38 \\
2.03 \\
3.75 \\
3.96\end{array}$ \\
\hline \multicolumn{4}{|c|}{ Semi-Locked } \\
\hline $\begin{array}{r}2.0 \\
4.0 \\
6.0 \\
8.0 \\
10.0 \\
12.0 \\
14.0 \\
16.0 \\
18.0 \\
20.0 \\
22.0 \\
28.0 \\
30.0 \\
32.0 \\
34.0 \\
36.0 \\
42.0 \\
54.0 \\
58.0 \\
70.0 \\
80.0\end{array}$ & $\begin{array}{r}11.30 \\
5.60 \\
1.80 \\
1.30 \\
1.60 \\
0.50 \\
0.80 \\
0.50 \\
0.30 \\
0.30 \\
0.30 \\
0.30 \\
0.50 \\
0.30 \\
0.30 \\
0.30 \\
0.30 \\
0.30 \\
0.30 \\
0.30 \\
0.30\end{array}$ & $\begin{array}{c}18.08 \\
5.01 \\
0.94 \\
0.43 \\
0.75 \\
0.06 \\
0.26 \\
0.14 \\
0.05 \\
0.05 \\
0.07 \\
0 . .0 \\
0.10 \\
0.04 \\
0.05 \\
0.07 \\
0.03 \\
0 . .0 \\
0.04 \\
0.02 \\
0.03\end{array}$ & \begin{tabular}{r}
0.20 \\
0.45 \\
0.29 \\
0.31 \\
1.06 \\
0.15 \\
1.01 \\
0.82 \\
0.41 \\
0.61 \\
1.12 \\
\hdashline$\ldots$. \\
3.84 \\
1.81 \\
2.60 \\
4.74 \\
3.37 \\
$\ldots . .6$ \\
11.17 \\
7.47 \\
19.54
\end{tabular} \\
\hline \multicolumn{4}{|l|}{ Free } \\
\hline $\begin{array}{r}2.0 \\
4.0 \\
6.0 \\
8.0 \\
10.0 \\
12.0 \\
14.0 \\
16.0 \\
22.0 \\
24.0 \\
26.0 \\
34.0 \\
38.0 \\
50.0 \\
58.0\end{array}$ & $\begin{array}{l}13.20 \\
7.40 \\
2.60 \\
2.40 \\
0.80 \\
0.30 \\
0.80 \\
0.30 \\
0.30 \\
0.50 \\
0.30 \\
0.30 \\
0.30 \\
0.30 \\
0.30\end{array}$ & \begin{tabular}{r}
20.85 \\
6.56 \\
1.37 \\
1.36 \\
0.34 \\
$0 . .$. \\
0.32 \\
0.10 \\
\hdashline .1. \\
0.13 \\
0.09 \\
0.01 \\
0.05 \\
0.02 \\
0.04
\end{tabular} & $\begin{array}{l}0.23 \\
0.59 \\
0.42 \\
0.98 \\
0.48 \\
\ldots . . \\
1.22 \\
0.56 \\
\ldots . .5 \\
2.56 \\
2.19 \\
0.57 \\
3.95 \\
2.89 \\
9.81\end{array}$ \\
\hline
\end{tabular}


Table 2.8-2 Pyrite Size Distribution for 28 mesh x 0 Pittsburgh \# 8 Coal

\begin{tabular}{|c|c|c|c|}
\hline $\begin{array}{c}\text { size, } \\
\text { micron }\end{array}$ & $\begin{array}{l}\text { 2-D Frequency } \\
\text { Distribution, } x \\
\end{array}$ & $\begin{array}{l}\text { 3-D Frequency } \\
\text { Distribution, } x\end{array}$ & $\begin{array}{c}\text { Volume } \\
\text { Distribution, } x\end{array}$ \\
\hline \multicolumn{4}{|l|}{ Locked } \\
\hline $\begin{array}{r}2.0 \\
4.0 \\
6.0 \\
8.0 \\
10.0 \\
12.0 \\
14.0 \\
16.0 \\
18.0 \\
20.0 \\
22.0 \\
24.0 \\
26.0 \\
28.0 \\
30.0 \\
40.0 \\
75.0 \\
80.0 \\
100.0\end{array}$ & $\begin{array}{r}21.70 \\
8.60 \\
3.20 \\
2.80 \\
1.40 \\
0.80 \\
0.60 \\
0.40 \\
0.40 \\
0.20 \\
0.20 \\
0.20 \\
0.40 \\
0.20 \\
0.20 \\
0.20 \\
0.20 \\
0.20 \\
0.20\end{array}$ & $\begin{array}{r}33.12 \\
7.08 \\
1.58 \\
1.36 \\
0.55 \\
0.25 \\
0.17 \\
0.08 \\
0.11 \\
0.02 \\
0.02 \\
0.00 \\
0.10 \\
0.04 \\
0.06 \\
0.02 \\
0 . .2 \\
0.02 \\
0.01\end{array}$ & \begin{tabular}{r}
0.37 \\
0.64 \\
0.48 \\
0.98 \\
0.78 \\
0.60 \\
0.66 \\
0.47 \\
0.87 \\
0.26 \\
0.27 \\
0.02 \\
2.36 \\
1.10 \\
2.10 \\
1.89 \\
\hdashline$\ldots . .27$ \\
15.27 \\
15.42
\end{tabular} \\
\hline \multicolumn{4}{|c|}{ Semi-Locked } \\
\hline $\begin{array}{r}2.0 \\
4.0 \\
6.0 \\
8.0 \\
10.0 \\
12.0 \\
14.0 \\
16.0 \\
18.0 \\
20.0 \\
22.0 \\
24.0 \\
26.0 \\
32.0 \\
34.0 \\
36.0 \\
40.0 \\
42.0 \\
52.0 \\
56.0 \\
58.0 \\
60.0 \\
62.0 \\
120.0\end{array}$ & $\begin{array}{r}10.60 \\
4.80 \\
3.60 \\
1.40 \\
1.20 \\
0.60 \\
0.20 \\
0.20 \\
0.40 \\
0.40 \\
0.20 \\
0.20 \\
0.20 \\
0.20 \\
0.20 \\
0.20 \\
0.20 \\
0.20 \\
0.20 \\
0.20 \\
0.20 \\
0.20 \\
0.20 \\
0.20\end{array}$ & \begin{tabular}{r}
15.90 \\
3.50 \\
2.21 \\
0.56 \\
0.51 \\
0.23 \\
0.02 \\
\hdashline. .0 \\
0.08 \\
0.10 \\
0.03 \\
0.03 \\
0.05 \\
.. .0 \\
0.02 \\
0.04 \\
0.00 \\
0.04 \\
...- \\
...- \\
0.02 \\
0.03 \\
0.04 \\
0.01
\end{tabular} & \begin{tabular}{c}
0.18 \\
0.32 \\
0.67 \\
0.41 \\
0.72 \\
0.55 \\
0.07 \\
\hdashline. .6 \\
0.64 \\
1.16 \\
0.42 \\
0.61 \\
1.13 \\
\hdashline$\ldots .$. \\
1.37 \\
2.33 \\
0.36 \\
4.35 \\
$-\ldots .$. \\
$-\ldots .$. \\
5.43 \\
7.69 \\
13.95 \\
15.56
\end{tabular} \\
\hline \multicolumn{4}{|l|}{ Free } \\
\hline $\begin{array}{r}2.0 \\
4.0 \\
6.0 \\
8.0 \\
10.0 \\
12.0 \\
14.0 \\
16.0 \\
18.0 \\
20.0 \\
22.0 \\
24.0 \\
28.0\end{array}$ & $\begin{array}{r}13.70 \\
10.20 \\
4.00 \\
1.80 \\
0.40 \\
0.20 \\
0.20 \\
0.20 \\
0.20 \\
0.20 \\
0.20 \\
0.20 \\
0.20\end{array}$ & $\begin{array}{c}19.59 \\
8.51 \\
2.48 \\
1.01 \\
0.16 \\
0.04 \\
0.04 \\
0.03 \\
0.03 \\
0.03 \\
0.04 \\
0.05 \\
0.05\end{array}$ & $\begin{array}{l}0.22 \\
0.77 \\
0.76 \\
0.73 \\
0.22 \\
0.10 \\
0.14 \\
0.19 \\
0.27 \\
0.38 \\
0.58 \\
1.07 \\
1.41\end{array}$ \\
\hline
\end{tabular}


Table 2.8-3 Pyrite Size Distribution for 28 mesh x 0 Illinois \# 6 Coal

\begin{tabular}{|c|c|c|c|}
\hline $\begin{array}{c}\text { size, } \\
\text { micron }\end{array}$ & $\begin{array}{l}\text { 2-0 Frequency } \\
\text { Distribution, } x\end{array}$ & $\begin{array}{l}\text { 3-D Frequency } \\
\text { Distribution, } x\end{array}$ & $\begin{array}{c}\text { Volume } \\
\text { Distribution, } \%\end{array}$ \\
\hline \multicolumn{4}{|l|}{ Locked } \\
\hline $\begin{array}{r}2.0 \\
4.0 \\
6.0 \\
8.0 \\
10.0 \\
12.0 \\
14.0 \\
16.0 \\
18.0 \\
20.0 \\
24.0 \\
26.0 \\
28.0 \\
30.0 \\
32.0 \\
34.0 \\
36.0 \\
46.0 \\
50.0 \\
90.0 \\
170.0\end{array}$ & $\begin{array}{r}11.50 \\
11.80 \\
6.40 \\
4.40 \\
2.00 \\
0.40 \\
0.60 \\
0.20 \\
0.20 \\
0.20 \\
0.40 \\
0.40 \\
0.20 \\
0.40 \\
0.40 \\
0.20 \\
0.20 \\
0.20 \\
0.20 \\
0.20 \\
0.20\end{array}$ & \begin{tabular}{r}
17.29 \\
10.34 \\
3.98 \\
2.54 \\
1.09 \\
0.07 \\
0.24 \\
0.03 \\
0.02 \\
0.02 \\
\hdashline 0.08 \\
0.08 \\
0.07 \\
0.10 \\
0.03 \\
0.05 \\
0.00 \\
0.04 \\
0.01 \\
0.01
\end{tabular} & \begin{tabular}{r}
0.06 \\
0.27 \\
0.35 \\
0.53 \\
0.44 \\
0.05 \\
0.27 \\
0.05 \\
0.06 \\
0.07 \\
\hdashline. .6 \\
0.61 \\
\hdashline. .5 \\
0.75 \\
1.28 \\
0.56 \\
1.05 \\
0.19 \\
1.86 \\
2.58 \\
10.31
\end{tabular} \\
\hline \multicolumn{4}{|c|}{ Semi-Locked } \\
\hline $\begin{array}{r}2.0 \\
4.0 \\
6.0 \\
8.0 \\
10.0 \\
12.0 \\
14.0 \\
16.0 \\
18.0 \\
20.0 \\
24.0 \\
26.0 \\
28.0 \\
30.0 \\
32.0 \\
38.0 \\
40.0 \\
50.0 \\
54.0 \\
60.0 \\
64.0 \\
70.0\end{array}$ & $\begin{array}{l}8.30 \\
7.70 \\
2.20 \\
2.00 \\
0.60 \\
0.20 \\
0.00 \\
0.60 \\
0.40 \\
0.20 \\
0.20 \\
0.20 \\
0.20 \\
0.20 \\
0.20 \\
0.20 \\
0.20 \\
0.20 \\
0.20 \\
0.20 \\
0.20 \\
0.20\end{array}$ & $\begin{array}{r}12.91 \\
7.39 \\
1.23 \\
1.20 \\
0.25 \\
-\ldots .0 \\
0.16 \\
0.19 \\
0.13 \\
0.05 \\
-0.03 \\
0.03 \\
0.03 \\
0.03 \\
0.05 \\
-\ldots .05 \\
0.05 \\
0.0 \\
0.02 \\
0.01 \\
0.02 \\
0.03\end{array}$ & \begin{tabular}{l}
0.04 \\
0.19 \\
0.11 \\
0.25 \\
0.10 \\
-1. \\
0.18 \\
0.32 \\
0.31 \\
0.16 \\
$-\cdots .$. \\
0.19 \\
0.26 \\
0.37 \\
0.66 \\
\hdashline 1.30 \\
\hdashline..- \\
1.35 \\
0.76 \\
2.60 \\
3.66
\end{tabular} \\
\hline \multicolumn{4}{|l|}{ Eree } \\
\hline $\begin{array}{r}2.0 \\
4.0 \\
6.0 \\
8.0 \\
10.0 \\
12.0 \\
14.0 \\
16.0 \\
20.0 \\
26.0 \\
40.0 \\
50.0 \\
120.0 \\
430.0\end{array}$ & $\begin{array}{r}17.00 \\
7.70 \\
3.30 \\
1.60 \\
1.30 \\
1.10 \\
0.70 \\
0.20 \\
0.20 \\
0.20 \\
0.20 \\
0.20 \\
0.20 \\
0.20\end{array}$ & $\begin{array}{r}28.89 \\
7.08 \\
2.16 \\
0.71 \\
0.51 \\
0.45 \\
0.31 \\
0.07 \\
0.04 \\
0.04 \\
0.01 \\
0.02 \\
0.01 \\
0.00\end{array}$ & $\begin{array}{r}0.09 \\
0.19 \\
0.19 \\
0.15 \\
0.21 \\
0.32 \\
0.35 \\
0.12 \\
0.14 \\
0.26 \\
0.35 \\
1.21 \\
4.63 \\
58.28\end{array}$ \\
\hline
\end{tabular}


Table 2.8-4 Pyrite Size Distribution for 200 mesh x 0 Upper Freeport Coal

\begin{tabular}{|c|c|c|c|}
\hline $\begin{array}{c}\text { size, } \\
\text { micron }\end{array}$ & $\begin{array}{l}\text { 2-D Frequency } \\
\text { Distribution, } \%\end{array}$ & $\begin{array}{l}\text { 3-D Frequency } \\
\text { Distribution, } x\end{array}$ & $\begin{array}{l}\text { Volume } \\
\text { Distribution, } x\end{array}$ \\
\hline \multicolumn{4}{|l|}{ Locked } \\
\hline $\begin{array}{r}2.0 \\
4.0 \\
6.0 \\
8.0 \\
10.0\end{array}$ & $\begin{array}{l}9.00 \\
1.60 \\
1.00 \\
0.40 \\
0.20\end{array}$ & $\begin{array}{r}14.41 \\
1.24 \\
0.63 \\
0.21 \\
0.11\end{array}$ & $\begin{array}{l}0.68 \\
0.47 \\
0.81 \\
0.63 \\
0.65\end{array}$ \\
\hline \multicolumn{4}{|c|}{ Semi-Locked } \\
\hline $\begin{array}{r}2.0 \\
4.0 \\
6.0 \\
8.0 \\
10.0 \\
12.0 \\
14.0 \\
16.0 \\
18.0 \\
20.0 \\
24.0 \\
40.0\end{array}$ & $\begin{array}{r}15.90 \\
9.60 \\
4.80 \\
2.60 \\
1.20 \\
0.60 \\
0.20 \\
0.40 \\
0.20 \\
0.20 \\
0.20 \\
0.20\end{array}$ & $\begin{array}{r}23.48 \\
7.72 \\
2.85 \\
1.32 \\
0.52 \\
0.23 \\
0.01 \\
0.12 \\
0.04 \\
0.06 \\
0.05 \\
0.02\end{array}$ & $\begin{array}{l}1.10 \\
2.91 \\
3.62 \\
3.98 \\
3.04 \\
2.34 \\
0.09 \\
3.00 \\
1.47 \\
2.81 \\
3.72 \\
7.78\end{array}$ \\
\hline \multicolumn{4}{|l|}{ Free } \\
\hline $\begin{array}{r}2.0 \\
4.0 \\
6.0 \\
8.0 \\
10.0 \\
12.0 \\
14.0 \\
16.0 \\
18.0 \\
20.0 \\
22.0 \\
24.0 \\
38.0\end{array}$ & $\begin{array}{r}18.90 \\
14.60 \\
7.00 \\
3.60 \\
3.20 \\
1.20 \\
1.00 \\
0.80 \\
0.60 \\
0.20 \\
0.20 \\
0.20 \\
0.20\end{array}$ & $\begin{array}{r}26.99 \\
11.80 \\
4.07 \\
1.46 \\
1.44 \\
0.35 \\
0.28 \\
0.23 \\
0.19 \\
0.04 \\
0.04 \\
0.07 \\
0.02\end{array}$ & $\begin{array}{l}1.27 \\
4.44 \\
5.17 \\
4.39 \\
8.45 \\
3.57 \\
4.54 \\
5.48 \\
6.68 \\
1.71 \\
2.67 \\
5.32 \\
7.24\end{array}$ \\
\hline
\end{tabular}


Table 2.8-5 Pyrite Size Distribution for 200 mesh x 0 Pittsburgh \# 8 Coal

\begin{tabular}{|c|c|c|c|}
\hline $\begin{array}{l}\text { Sixe, } \\
\text { micron }\end{array}$ & $\begin{array}{l}\text { 2-D Frequency } \\
\text { Distribution, } \%\end{array}$ & $\begin{array}{l}\text { 3-D Frequency } \\
\text { Distribution, } x\end{array}$ & $\begin{array}{l}\text { Volume } \\
\text { Distribution, } x\end{array}$ \\
\hline \multicolumn{4}{|l|}{ Locked } \\
\hline $\begin{array}{r}2.0 \\
4.0 \\
6.0 \\
8.0 \\
10.0 \\
12.0 \\
14.0 \\
22.0\end{array}$ & $\begin{array}{l}5.80 \\
2.20 \\
1.60 \\
0.40 \\
0.40 \\
0.20 \\
0.20 \\
0.20\end{array}$ & $\begin{array}{l}8.92 \\
1.65 \\
1.06 \\
0.15 \\
0.17 \\
0.06 \\
0.08 \\
0.04\end{array}$ & $\begin{array}{l}0.36 \\
0.54 \\
1.16 \\
0.38 \\
0.86 \\
0.53 \\
1.17 \\
2.11\end{array}$ \\
\hline \multicolumn{4}{|c|}{ Semi-Locked } \\
\hline $\begin{array}{r}2.0 \\
4.0 \\
6.0 \\
8.0 \\
10.0 \\
12.0 \\
14.0 \\
16.0 \\
18.0 \\
20.0 \\
22.0 \\
30.0\end{array}$ & $\begin{array}{r}21.20 \\
11.00 \\
4.10 \\
3.20 \\
1.60 \\
0.40 \\
0.40 \\
0.40 \\
0.20 \\
0.20 \\
0.20 \\
0.20\end{array}$ & $\begin{array}{l}31.92 \\
9.19 \\
2.17 \\
1.62 \\
0.76 \\
0.09 \\
0.10 \\
0.12 \\
0.04 \\
0.04 \\
0.07 \\
0.03\end{array}$ & $\begin{array}{l}1.30 \\
3.00 \\
2.39 \\
4.22 \\
3.89 \\
0.83 \\
1.35 \\
2.55 \\
1.13 \\
1.78 \\
3.54 \\
4.46\end{array}$ \\
\hline \multicolumn{4}{|l|}{ Eree } \\
\hline $\begin{array}{r}2.0 \\
4.0 \\
6.0 \\
8.0 \\
10.0 \\
12.0 \\
14.0 \\
16.0 \\
18.0 \\
20.0 \\
22.0 \\
24.0 \\
26.0 \\
40.0 \\
50.0\end{array}$ & $\begin{array}{r}16.50 \\
14.20 \\
5.40 \\
4.10 \\
1.80 \\
0.70 \\
0.50 \\
0.50 \\
0.50 \\
0.50 \\
0.40 \\
0.20 \\
0.20 \\
0.20 \\
0.20\end{array}$ & $\begin{array}{r}23.23 \\
11.84 \\
2.90 \\
2.11 \\
0.80 \\
0.20 \\
0.10 \\
0.09 \\
0.10 \\
0.12 \\
0.11 \\
0.04 \\
0.06 \\
0.01 \\
0.02\end{array}$ & $\begin{array}{r}0.95 \\
3.86 \\
3.19 \\
5.50 \\
4.06 \\
1.79 \\
1.34 \\
1.93 \\
2.87 \\
4.75 \\
5.74 \\
2.82 \\
5.52 \\
4.09 \\
14.04\end{array}$ \\
\hline
\end{tabular}


Table 2.8-6 Pyrite Size Distribution for 200 mesh x 0 Illinois \# 6 Coal

\begin{tabular}{|c|c|c|c|}
\hline $\begin{array}{l}\text { size, } \\
\text { micron }\end{array}$ & $\begin{array}{l}\text { 2-D Frequency } \\
\text { Distribution, } x\end{array}$ & $\begin{array}{l}\text { 3-D Frequency } \\
\text { Distribution, } x\end{array}$ & $\begin{array}{c}\text { Volume } \\
\text { Distribution, } x\end{array}$ \\
\hline \multicolumn{4}{|l|}{ Locked } \\
\hline $\begin{array}{r}2.0 \\
4.0 \\
6.0 \\
8.0 \\
10.0 \\
12.0 \\
20.0 \\
40.0 \\
50.0\end{array}$ & $\begin{array}{l}5.30 \\
3.40 \\
2.50 \\
1.10 \\
0.20 \\
0.20 \\
0.20 \\
0.20 \\
0.20\end{array}$ & $\begin{array}{l}7.42 \\
2.43 \\
1.51 \\
0.61 \\
0.06 \\
0.09 \\
0.03 \\
0.01 \\
0.02\end{array}$ & $\begin{array}{r}0.29 \\
0.77 \\
1.62 \\
1.53 \\
0.32 \\
0.74 \\
1.35 \\
2.74 \\
13.08\end{array}$ \\
\hline \multicolumn{4}{|c|}{ Semi-Locked } \\
\hline $\begin{array}{r}2.0 \\
4.0 \\
6.0 \\
8.0 \\
10.0 \\
12.0 \\
14.0 \\
16.0 \\
18.0 \\
20.0 \\
28.0 \\
34.0 \\
42.0\end{array}$ & $\begin{array}{r}21.80 \\
12.00 \\
4.00 \\
3.60 \\
1.30 \\
0.80 \\
0.80 \\
0.40 \\
0.60 \\
0.20 \\
0.20 \\
0.20 \\
0.20\end{array}$ & $\begin{array}{l}31.37 \\
9.74 \\
1.92 \\
1.82 \\
0.47 \\
0.20 \\
0.25 \\
0.06 \\
0.20 \\
0.06 \\
0.01 \\
0.02 \\
0.03\end{array}$ & $\begin{array}{l}1.24 \\
3.08 \\
2.05 \\
4.59 \\
2.33 \\
1.74 \\
3.38 \\
1.20 \\
5.68 \\
2.49 \\
1.62 \\
4.67 \\
9.43\end{array}$ \\
\hline \multicolumn{4}{|l|}{ Free } \\
\hline $\begin{array}{r}2.0 \\
4.0 \\
6.0 \\
8.0 \\
10.0 \\
12.0 \\
14.0 \\
16.0 \\
20.0 \\
38.0 \\
40.0\end{array}$ & $\begin{array}{r}20.00 \\
9.90 \\
4.40 \\
2.30 \\
1.70 \\
0.90 \\
0.60 \\
0.40 \\
0.20 \\
0.20 \\
0.20\end{array}$ & $\begin{array}{c}29.02 \\
7.79 \\
2.47 \\
0.96 \\
0.69 \\
0.30 \\
0.19 \\
0.15 \\
0.05 \\
0 . . \\
0.05\end{array}$ & \begin{tabular}{c}
1.15 \\
2.46 \\
2.64 \\
2.43 \\
3.39 \\
2.58 \\
2.61 \\
2.97 \\
1.86 \\
\hdashline. .9 \\
16.09
\end{tabular} \\
\hline
\end{tabular}


Table 2.9-1 Experimental Conditions for Grinding Study

\begin{tabular}{lcc}
\hline Variable & Level 1 & Level 2 \\
\hline Particle Size & 28 mesh x 0 & 200 mesh x 0 \\
Grinding Method & DRY & WET \\
Slurry & & \\
Concentration, \% & 2 & 4 \\
PCR & & \\
$\quad$ Upper Freeport Coal & 0.25 & 0.50 \\
$\quad$ Pittsburgh \# 8 & $n .50$ & 1.00 \\
$\quad$ Illinois \# 6 & $(0.50$ & 1.00 \\
Mixing Time, s & 15 & 30 \\
Mixing Speed, Hz & 150 & 233 \\
(rpm) & $(9000)$ & $(14000)$ \\
\hline
\end{tabular}

"PCR: Pentane to Coal Ratio 
Table 2.9-2 Operation Variables Significance on Energy Recovery (BTU)

\begin{tabular}{|c|c|c|c|c|c|c|}
\hline & $\begin{array}{l}\text { Particle } \\
\text { Size }\end{array}$ & $\begin{array}{l}\text { Grinding } \\
\text { Method }\end{array}$ & $\begin{array}{l}\text { Slurry } \\
\text { Conc. }\end{array}$ & PCR & $\begin{array}{l}\text { Agg. } \\
\text { Time }\end{array}$ & $\begin{array}{l}\text { Mixing } \\
\text { Speed }\end{array}$ \\
\hline Particle & UT & & & & & \\
\hline \multirow[t]{2}{*}{ Size } & P8 & & & & & \\
\hline & 16 & & & & & \\
\hline Grinding & UI & UI & & & & \\
\hline \multirow[t]{2}{*}{ Method } & P8 & P8 & & & & \\
\hline & 16 & & & & & \\
\hline Slurry & & & U & & & \\
\hline \multirow[t]{2}{*}{ Concentration. } & & & P8 & & & \\
\hline & & & 16 & & & \\
\hline \multirow{3}{*}{ PCR } & & & UI & UI & & \\
\hline & & P8 & P8 & P8 & & \\
\hline & & & & 16 & & \\
\hline Agglomeration & UI & UI & UI & UI & & \\
\hline Time & P8 & & & & P8 & \\
\hline Mixing & $\mathrm{UI}$ & UI & & & & \\
\hline Speed & & P8 & & & P8 & P8 \\
\hline
\end{tabular}
UI: Upper Freeport Coal
P8: Pittsburgh \# 8
I6: Illinois \# 6 
Table 29-3 Operation Variables Significance on Ash Rejection (ARJ)

\begin{tabular}{|c|c|c|c|c|c|c|}
\hline & $\begin{array}{c}\text { Particle } \\
\text { Jize }\end{array}$ & $\begin{array}{l}\text { Grinding } \\
\text { Method }\end{array}$ & $\begin{array}{l}\text { Slurry } \\
\text { Conc. }\end{array}$ & PC & $\begin{array}{l}\text { Ags } \\
\text { Time }\end{array}$ & $\begin{array}{r}\text { Mixing } \\
\text { Speed }\end{array}$ \\
\hline $\begin{array}{l}\text { Particle } \\
\text { Size }\end{array}$ & $\begin{array}{l}\text { P8 } \\
16\end{array}$ & & & & & \\
\hline $\begin{array}{l}\text { Grinding } \\
\text { Method }\end{array}$ & $\begin{array}{l}\text { UI } \\
\text { P8 } \\
16\end{array}$ & $\begin{array}{l}\text { UI } \\
\text { P8 } \\
16\end{array}$ & & & & \\
\hline $\begin{array}{l}\text { Slursy } \\
\text { Concentration }\end{array}$ & $\begin{array}{l}\text { P8 } \\
.6\end{array}$ & P8 & $\begin{array}{l}\text { P8 } \\
16\end{array}$ & & & \\
\hline PCR & & & & $\begin{array}{l}\text { P8 } \\
16\end{array}$ & & \\
\hline $\begin{array}{l}\text { Agglomeration } \\
\text { Time }\end{array}$ & & & & & & \\
\hline $\begin{array}{l}\text { Mixing } \\
\text { Speed }\end{array}$ & & & P8 & & & \\
\hline
\end{tabular}

UI: Upper Freeport Coal

P8: Pittsburgh $\neq 8$

I6: Illinois $\# 6$ 
Table 2.9-4 Average Values of Energy Recovery for the Statistically Significant Variables and Interactions

Energy Recovery, \%

\begin{tabular}{|c|c|c|c|}
\hline Term & $\begin{array}{c}\text { Upper } \\
\text { Freeport }\end{array}$ & $\begin{array}{c}\text { Pittsburgh } \\
\quad \# 8\end{array}$ & $\begin{array}{c}\text { Illinois } \\
\# 6\end{array}$ \\
\hline ALL & 94.92 & 73.77 & 58.78 \\
\hline \multicolumn{4}{|l|}{ Particle Size } \\
\hline 28 mesh $\times 0$ & 91.62 & 60.53 & 39.46 \\
\hline 200 mesh $\times 0$ & 98.23 & 87.01 & 78.11 \\
\hline \multicolumn{4}{|l|}{ Grinding Method } \\
\hline DRY & 94.29 & 74.75 & 59.18 \\
\hline WET & 95.55 & 72.79 & 58.39 \\
\hline \multicolumn{4}{|c|}{ Particle Size, Grinding Method } \\
\hline 28 mesh $\times 0$, DRY & 89.70 & 66.86 & 42.96 \\
\hline 28 mesh $x$ 0, WET & 93.52 & 54.20 & 35.96 \\
\hline 200 mesh $\times 0$, DRY & 98.88 & 82.64 & 75.39 \\
\hline 200 mesh $\times 0$, WET & 97.58 & 91.38 & 80.83 \\
\hline \multicolumn{4}{|l|}{ Slurry Concentration } \\
\hline $2 \%$ & 93.34 & 74.90 & 57.12 \\
\hline $4 \%$ & 96.50 & 72.64 & 60.45 \\
\hline \multicolumn{4}{|l|}{ PCR } \\
\hline $0.5^{\circ}$ & 92.75 & 71.83 & 56.82 \\
\hline $1.0^{\circ}$ & 97.09 & 75.71 & 60.75 \\
\hline \multicolumn{4}{|c|}{ Slurry Concentration, PCR } \\
\hline $2 \%, 0.5^{\circ}$ & 89.65 & 74.28 & 55.12 \\
\hline $2 \%, 1.0^{\circ}$ & 97.19 & 75.66 & 58.93 \\
\hline $4 \%, 0.5^{\circ}$ & 96.12 & 69.57 & 58.86 \\
\hline $4 \%, 1.0^{\circ}$ & 96.87 & 76.48 & 62.04 \\
\hline \multicolumn{4}{|c|}{ Particle Size, Agglomeration Time } \\
\hline 28 mesh $\times 0,15 \mathrm{~s}$ & 90.94 & 61.41 & 38.79 \\
\hline 28 mesh $\times 0,30 \mathrm{~s}$ & 92.28 & 59.66 & 40.13 \\
\hline 200 mesh $\times 0,15 \mathrm{~s}$ & 98.90 & 86.14 & 78.78 \\
\hline 200 mesh $\times 0,30 \mathrm{~s}$ & 97.56 & 87.88 & 77.44 \\
\hline \multicolumn{4}{|c|}{ Grinding Method, Mixing Speed } \\
\hline DRY, $150 \mathrm{~Hz}$ & 93.86 & 75.41 & 58.53 \\
\hline DRY, $233 \mathrm{~Hz}$ & 94.71 & 74.09 & 59.83 \\
\hline WET, $150 \mathrm{~Hz}$ & 95.98 & 72.13 & 59.04 \\
\hline WET, $233 \mathrm{~Hz}$ & 95.13 & 73.45 & 57.74 \\
\hline
\end{tabular}

$:$ PCR $=0.25$ and 0.5 for Upper Freeport Coal 
Table 2.9-5 Average Values of Ash Rejection for the Statistically Significant Variables and Interactions

Ash Rejection, \%

\begin{tabular}{|c|c|c|c|}
\hline Term & $\begin{array}{c}\text { Upper } \\
\text { Freeport }\end{array}$ & $\begin{array}{c}\text { Pittsburgh } \\
\# 8\end{array}$ & $\begin{array}{c}\text { Illinois } \\
\# 6\end{array}$ \\
\hline $\mathbf{A L}$ & 33.17 & 58.79 & 69.04 \\
\hline \multicolumn{4}{|l|}{ Particle Size } \\
\hline 28 mesh $x 0$ & 33.40 & 69.90 & 80.98 \\
\hline 200 mesh $\times 0$ & 32.95 & 47.69 & 57.09 \\
\hline \multicolumn{4}{|l|}{ Grinding Method } \\
\hline DRY & 21.40 & 46.35 & 62.19 \\
\hline WET & 44.95 & 71.24 & 75.88 \\
\hline \multicolumn{4}{|c|}{ Particle Size, Grinding Method } \\
\hline 28 mesh $x 0$, DRY & 33.81 & 66.52 & 79.68 \\
\hline 28 mesh $\times 0$, WET & 32.99 & 73.29 & 82.28 \\
\hline 200 mesh $\times 0$, DRY & 8.99 & 26.19 & 44.71 \\
\hline 200 mesh $\times 0$, WET & 56.90 & 69.19 & 69.48 \\
\hline \multicolumn{4}{|l|}{ Slurry Concentration } \\
\hline $2 \%$ & 35.86 & 60.28 & 72.22 \\
\hline $4 \%$ & 30.49 & 57.31 & 65.86 \\
\hline \multicolumn{4}{|l|}{ PCR } \\
\hline $0.5^{\circ}$ & 34.75 & 60.47 & 70.02 \\
\hline $1.0^{*}$ & 31.60 & 57.12 & 68.06 \\
\hline \multicolumn{4}{|c|}{ Particle Size, Slurry Concentration } \\
\hline 28 mesh $\times 0,2 \%$ & 36.62 & 70.45 & 81.89 \\
\hline 28 mesh $\times 0,4 \%$ & 30.19 & 69.36 & 80.07 \\
\hline 200 mesh $\times 0,2 \%$ & 35.10 & 50.11 & 62.54 \\
\hline 200 mesh $\times 0,4 \%$ & 30.79 & 45.27 & 51.65 \\
\hline
\end{tabular}

$\because$ PCR $=0.25$ and 0.5 for Upper Freeport Coal 
Table 2.10-1 Agglomeration Test Results Using Light Hydrocarbons for Upper Freeport Coal

\begin{tabular}{lcccc}
\hline Reagent & RCR & $\begin{array}{c}\text { ARJ } \\
\%\end{array}$ & $\begin{array}{c}\text { PSRJ } \\
\%\end{array}$ & $\begin{array}{c}\text { BTU } \\
\%\end{array}$ \\
\hline No Additives & 0 & 53.8 & 59.2 & $>99.9$ \\
\hline \multirow{2}{*}{ N-pentane } & $1 / 100$ & 49.1 & 56.4 & $>99.9$ \\
& $1 / 10$ & 27.3 & 50.1 & 99.5 \\
& $1 / 5$ & $*$ & $*$ & $*$ \\
\hline \multirow{2}{*}{ Cyclohexane } & $1 / 100$ & 50.2 & 63.3 & 99.9 \\
& $1 / 20$ & $*$ & $*$ & $*$ \\
& $1 / 10$ & $*$ & $*$ & $*$ \\
\hline \multirow{2}{*}{ N-heptane } & $1 / 100$ & 50.2 & 58.9 & 99.7 \\
& $1 / 20$ & $*$ & $*$ & $*$ \\
& $1 / 10$ & $*$ & $*$ & $*$ \\
\hline
\end{tabular}

* Cake formation during grinding 
Table 2.10-2 Agglomeration Test Results Using Light

Hydrocarbons for Pittsburgh \# 8 Coal

\begin{tabular}{lcccc}
\hline Reagent & RCR & ARJ & PSRJ & BTU \\
& & $\%$ & $\%$ & $\%$ \\
\hline No Additives & 0 & 63.4 & 62.8 & 79.6 \\
\hline N-pentane & $1 / 10$ & 59.8 & 61.3 & 82.7 \\
& $1 / 5$ & 61.8 & 59.1 & 83.6 \\
\hline Cyclohexane & $1 / 50$ & 60.1 & 57.1 & 81.8 \\
& $1 / 20$ & 51.7 & 62.3 & 83.2 \\
& $1 / 10$ & 45.1 & 55.1 & 82.2 \\
& $1 / 5$ & $*$ & $*$ & $*$ \\
\hline N-heptane & $1 / 50$ & 51.5 & 58.6 & 87.2 \\
& $1 / 20$ & 44.5 & 46.0 & 89.9 \\
& $1 / 10$ & 41.7 & 49.4 & 88.9 \\
& $1 / 5$ & $*$ & $*$ & $*$ \\
\hline
\end{tabular}

*ake formation during grinding 
Table 2.10-3 Agglomeration Test Results Using Light Hydrocarbons for Illinois \# 6 Coal

\begin{tabular}{lcccc}
\hline Reagent & RCR & ARJ & PSRJ & BTU \\
& & $\%$ & $\%$ & $\%$ \\
\hline No Additives & 0 & 62.4 & 60.0 & 77.7 \\
\hline N-pentane & $1 / 20$ & 52.7 & 40.4 & 82.3 \\
& $1 / 10$ & 58.3 & 48.7 & 81.8 \\
& $1 / 5$ & 57.7 & 49.1 & 80.1 \\
& $1 / 2$ & 60.8 & 55.1 & 79.0 \\
\hline Cyclohexane & $1 / 20$ & 61.4 & 58.1 & 82.8 \\
& $1 / 10$ & 58.3 & 71.8 & 81.4 \\
& $1 / 5$ & 56.8 & 62.8 & 78.5 \\
\hline N-heptane & $1 / 10$ & 62.4 & 62.4 & 75.7 \\
& $1 / 5$ & 59.9 & 64.7 & 78.7 \\
& $1 / 2$ & 66.1 & 62.8 & 64.3 \\
\hline
\end{tabular}


Table 2.10-4 Standard Deviation Within Replicates for the Agglomeration Tests Using Light Hydrocarbons During Grinding

\begin{tabular}{lc}
\hline $\begin{array}{l}\text { Response } \\
\text { Variable }\end{array}$ & $\begin{array}{c}\text { Standard Deviation, } \\
\text { Percentage Points }\end{array}$ \\
\hline $\begin{array}{l}\text { Energy } \\
\text { Recovery (BTU) }\end{array}$ & 4.29 \\
$\begin{array}{l}\text { Ash } \\
\text { Rejection (ARJ) }\end{array}$ & 4.63 \\
$\begin{array}{l}\text { Pyritic Sulfur } \\
\text { Rejection (PSRJ) }\end{array}$ & 5.59 \\
\hline
\end{tabular}


Table 2.10.1-1 Results of the Statistical Analysis of the Effects of Grinding Using N-pentane

Probability that the Result is NOT Equal to the Base Data (Without Additives)

\begin{tabular}{lcccl}
\hline COAL & RCR & ARJ & PSRJ & BTU \\
\hline Upper Freeport & $1 / 100$ & 0.219 & 0.463 & 1.000 \\
& $1 / 10$ & 0.010 & 0.106 & 0.591 \\
\hline \multirow{2}{*}{ Pittsburgh \# 8 } & $1 / 10$ & 0.312 & 0.686 & 0.337 \\
& $1 / 5$ & 0.614 & 0.375 & 0.248 \\
\hline \multirow{2}{*}{ Illinois \# 6 } & $1 / 20$ & 0.001 & 0.000 & 0.032 \\
& $1 / 10$ & 0.059 & 0.001 & 0.049 \\
& $1 / 5$ & 0.054 & 0.005 & 0.236 \\
& $1 / 2$ & 0.602 & 0.268 & 0.666 \\
\hline
\end{tabular}


Table 2.10.2-1 Results of the Statistical Analysis of the Effects of Grinding Using Cyclohexane

Probability that the Result is NOT Equal to the Base Data (Without Additives)

\begin{tabular}{lccll}
\hline COAL & RCR & ARJ & PSRJ & BTU \\
\hline Upper Freeport & $1 / 100$ & 0.307 & 0.491 & 0.676 \\
\hline \multirow{2}{*}{ Pittsburgh \# 8 } & $1 / 50$ & 0.341 & 0.220 & 0.463 \\
& $1 / 20$ & 0.049 & 0.911 & 0.286 \\
& $1 / 10$ & 0.021 & 0.140 & 0.394 \\
\hline \multirow{2}{*}{ Illinois \# 6 } & $1 / 20$ & 0.744 & 0.614 & 0.177 \\
& $1 / 10$ & 0.262 & 0.067 & 0.282 \\
& $1 / 5$ & 0.338 & 0.614 & 0.842 \\
\hline
\end{tabular}


Table 2.10.3-1 Results of the Statistical Analysis of the Effects of Grinding Using N-heptane

Probability that the Result is NOT Equal to the Base Data (Without Additives)

\begin{tabular}{lcccc}
\hline COAL & RCR & ARJ & PSRJ & BTU \\
\hline Upper Freeport & $1 / 100$ & 0.313 & 0.921 & 0.654 \\
\hline Pittsburgh \# 8 & $1 / 50$ & 0.047 & 0.325 & 0.092 \\
& $1 / 20$ & 0.019 & 0.035 & 0.053 \\
& $1 / 10$ & 0.015 & 0.053 & 0.064 \\
\hline Illinois \# 6 & $1 / 10$ & 0.996 & 0.347 & 0.288 \\
& $1 / 5$ & 0.240 & 0.092 & 0.622 \\
& $1 / 2$ & 0.105 & 0.271 & 0.001 \\
\hline
\end{tabular}




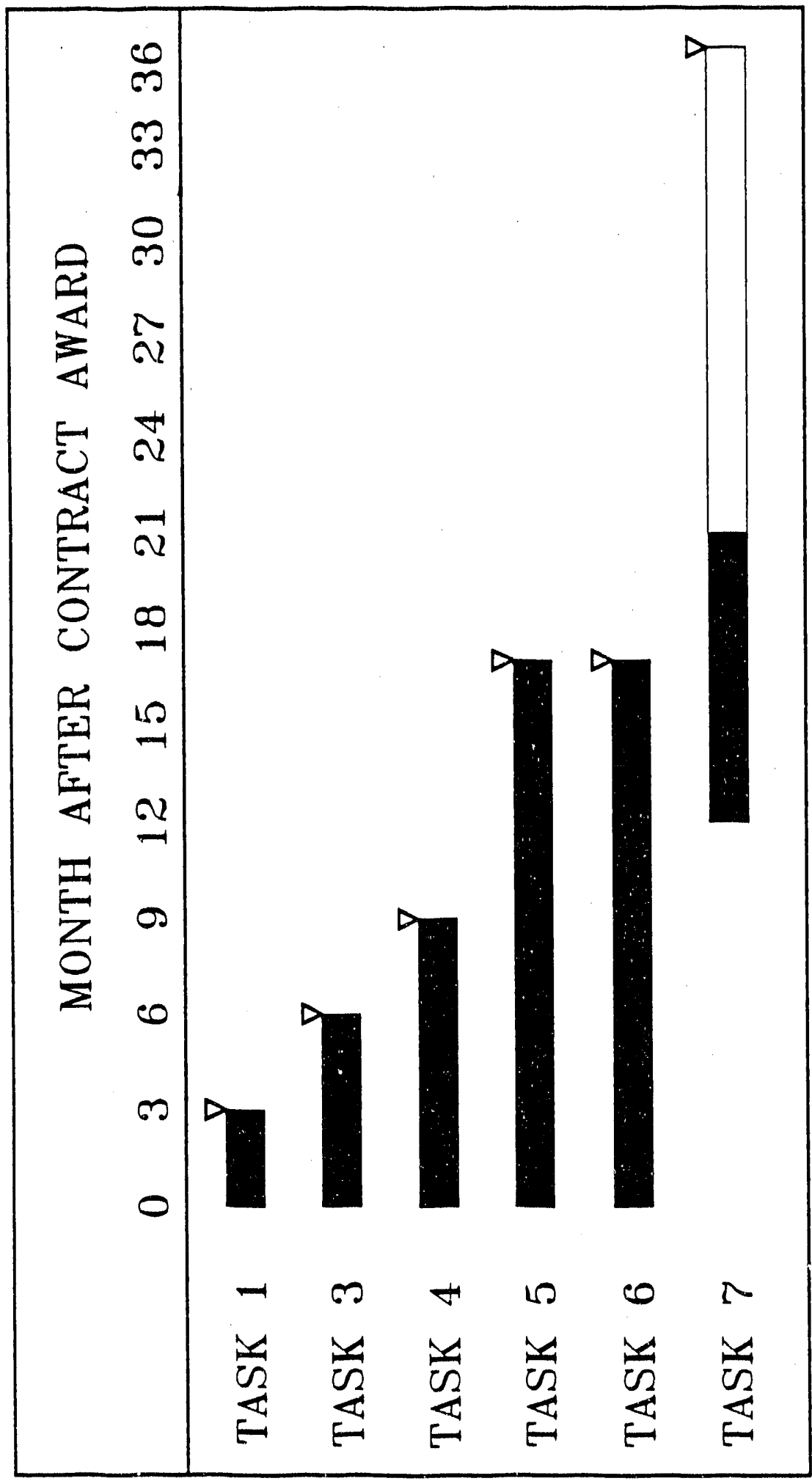

$\frac{0}{3}$

$\frac{1}{2}$

8

$\frac{9}{2}$ 


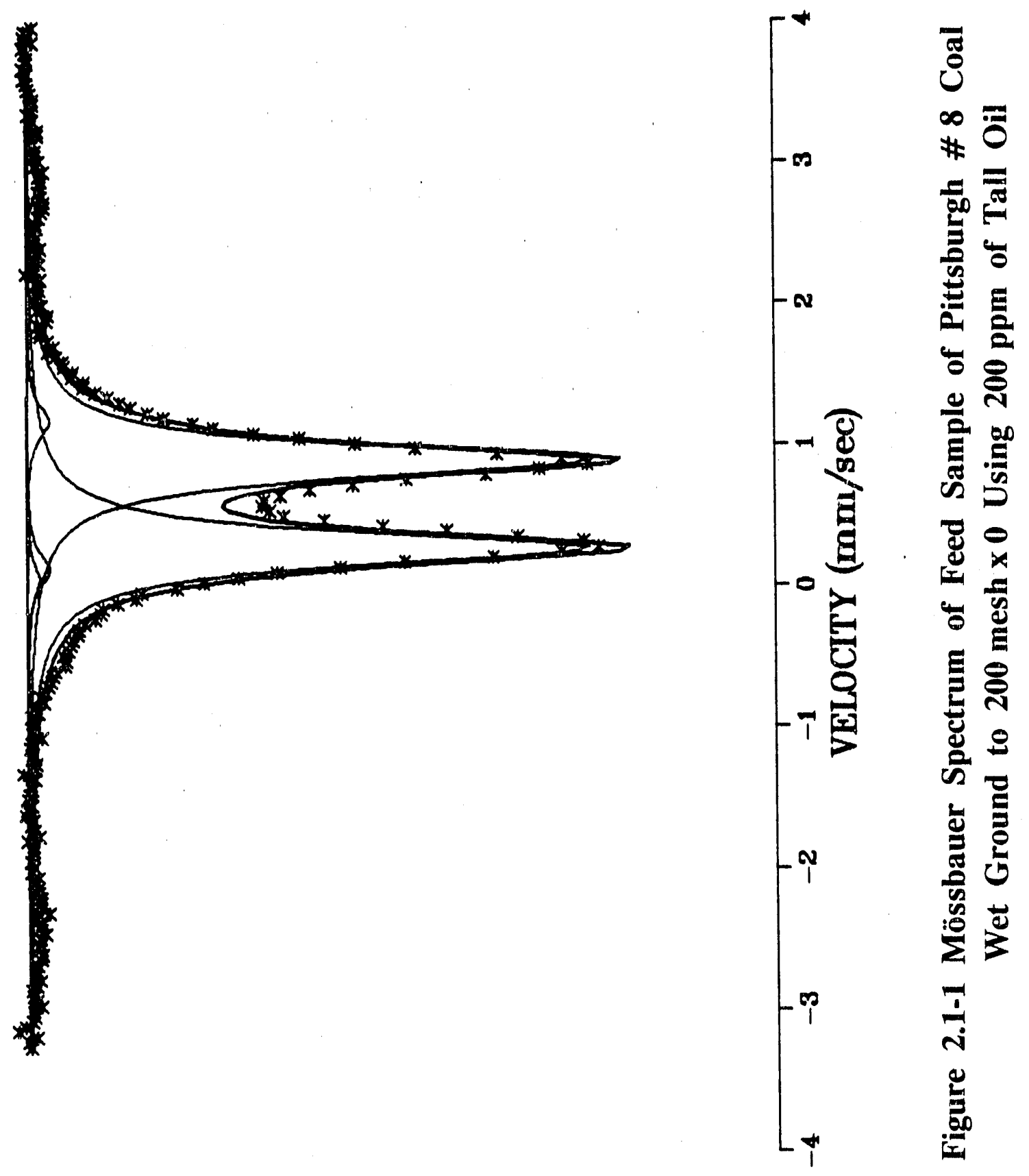

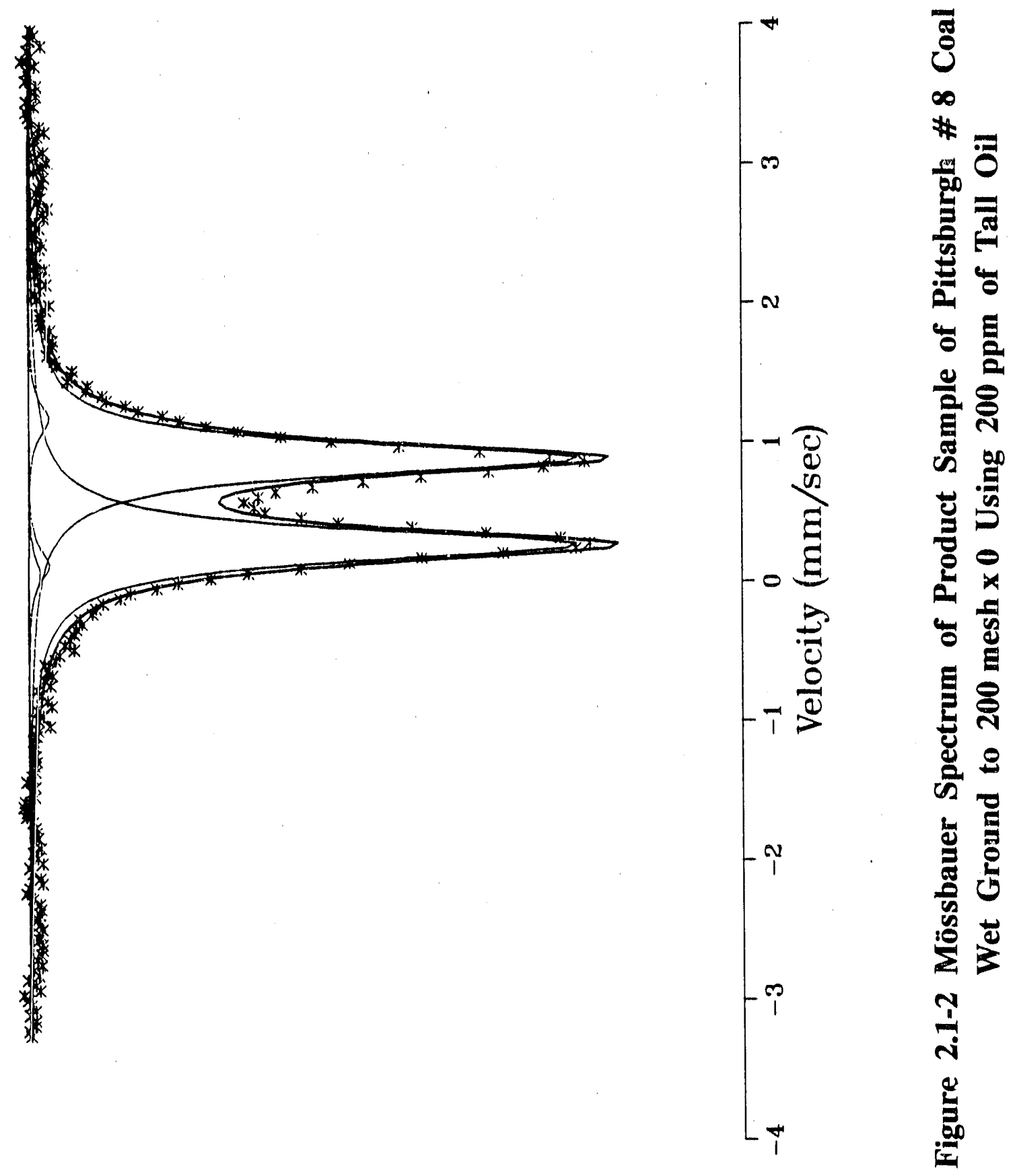

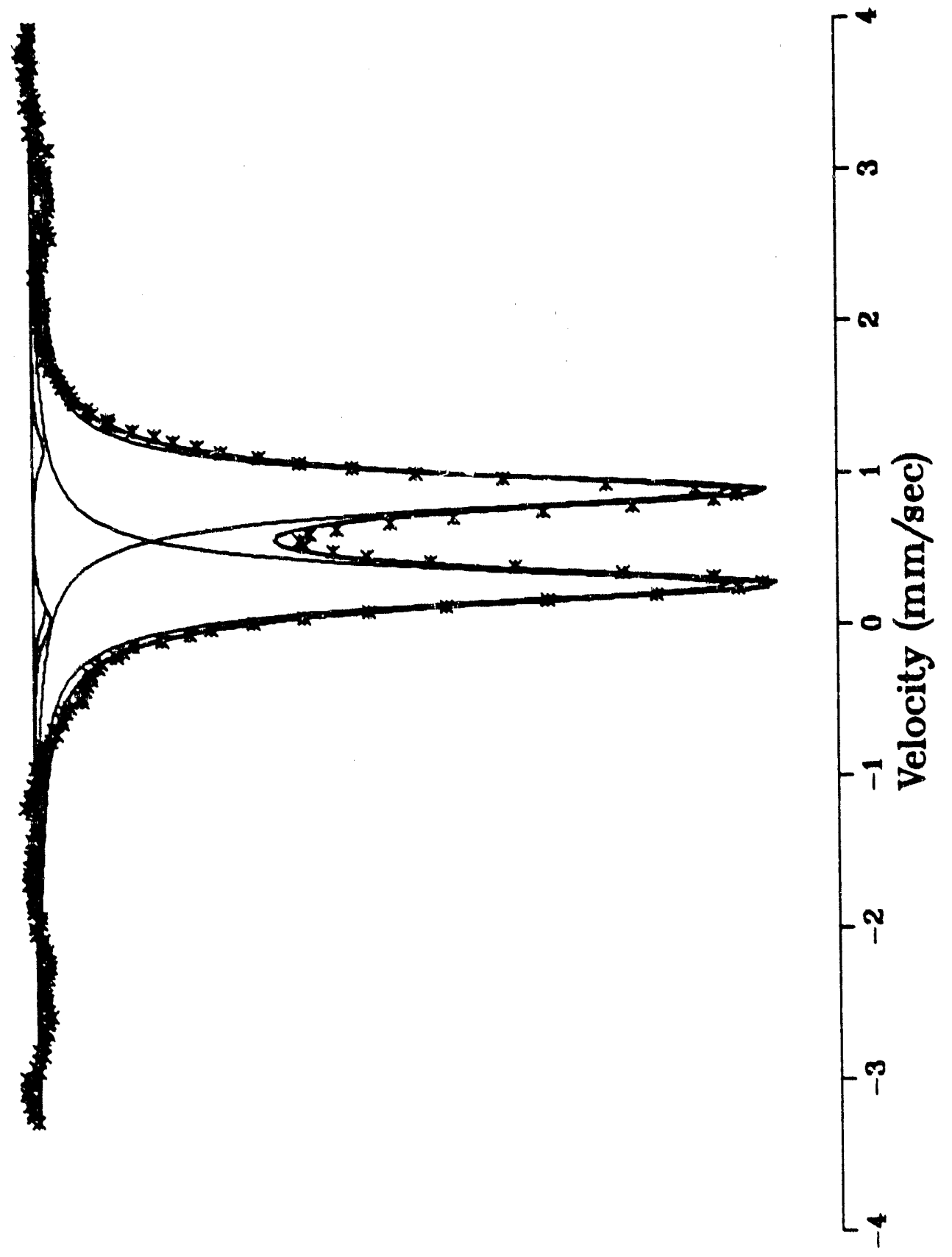

8

$\infty$

标

尊

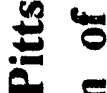

$\div$ 틍

을

苛

๖

일

늘

틀 尽

\&

㫐

$\sum 3$

i⿱

$\stackrel{5}{3}$

可 


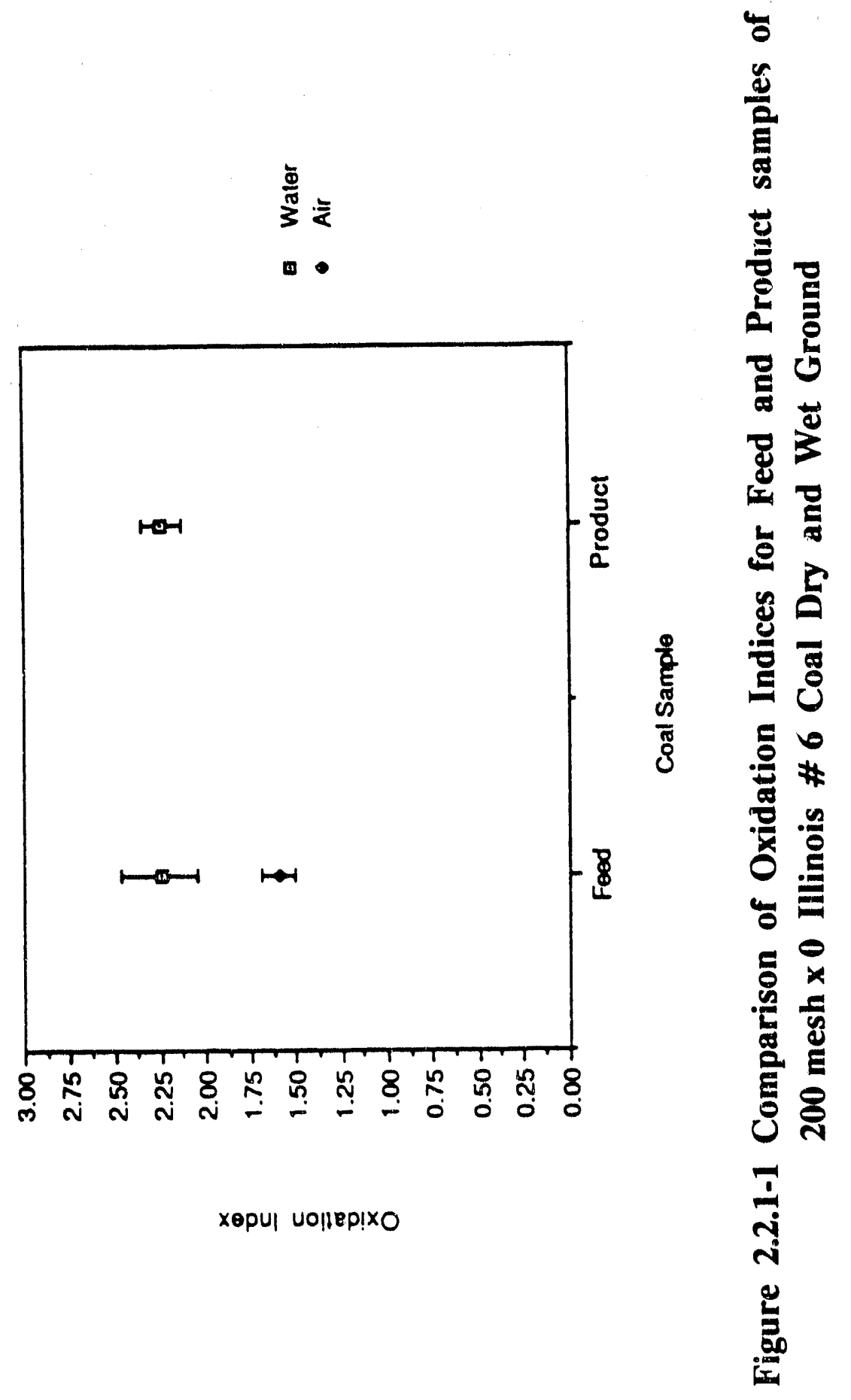




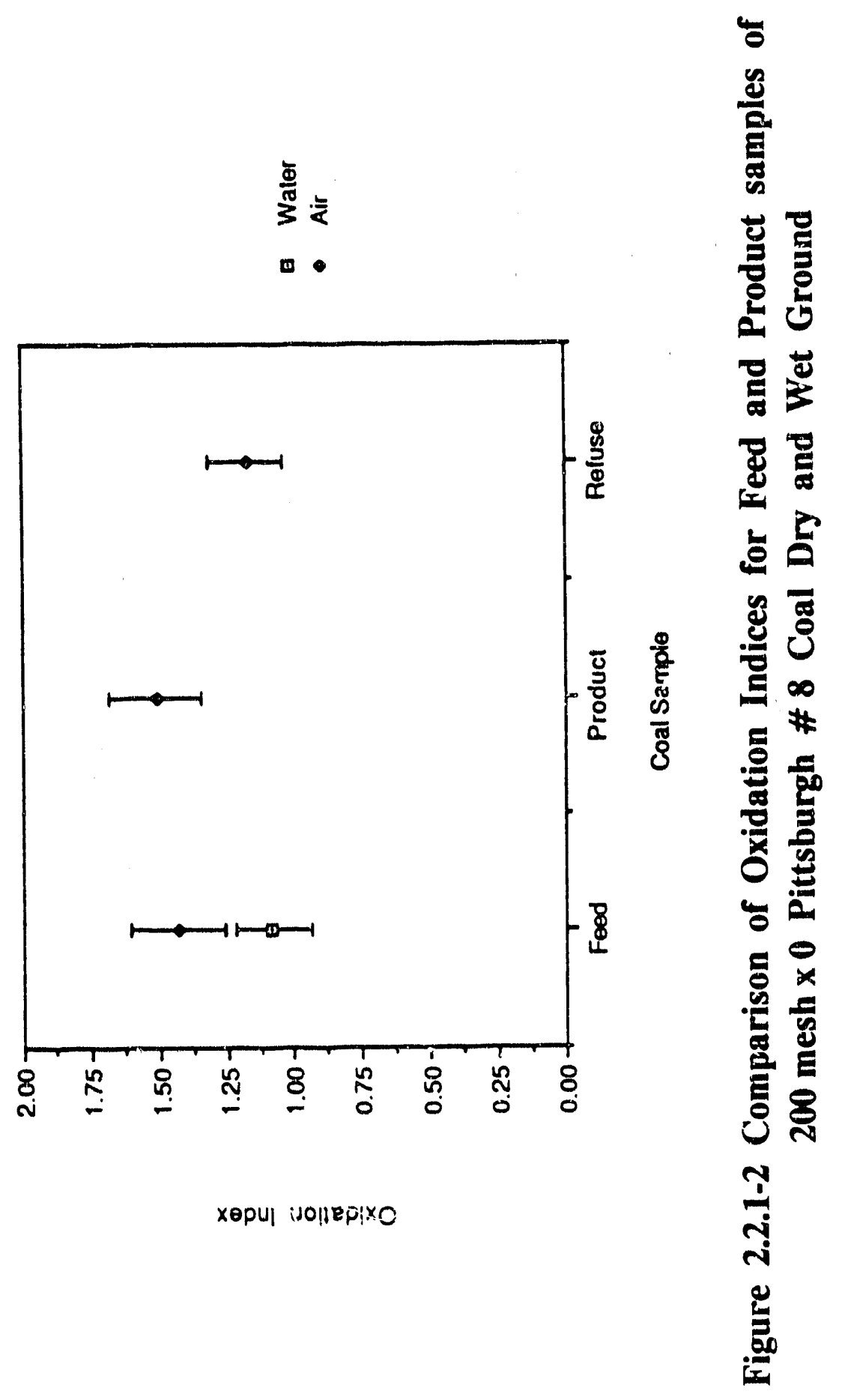




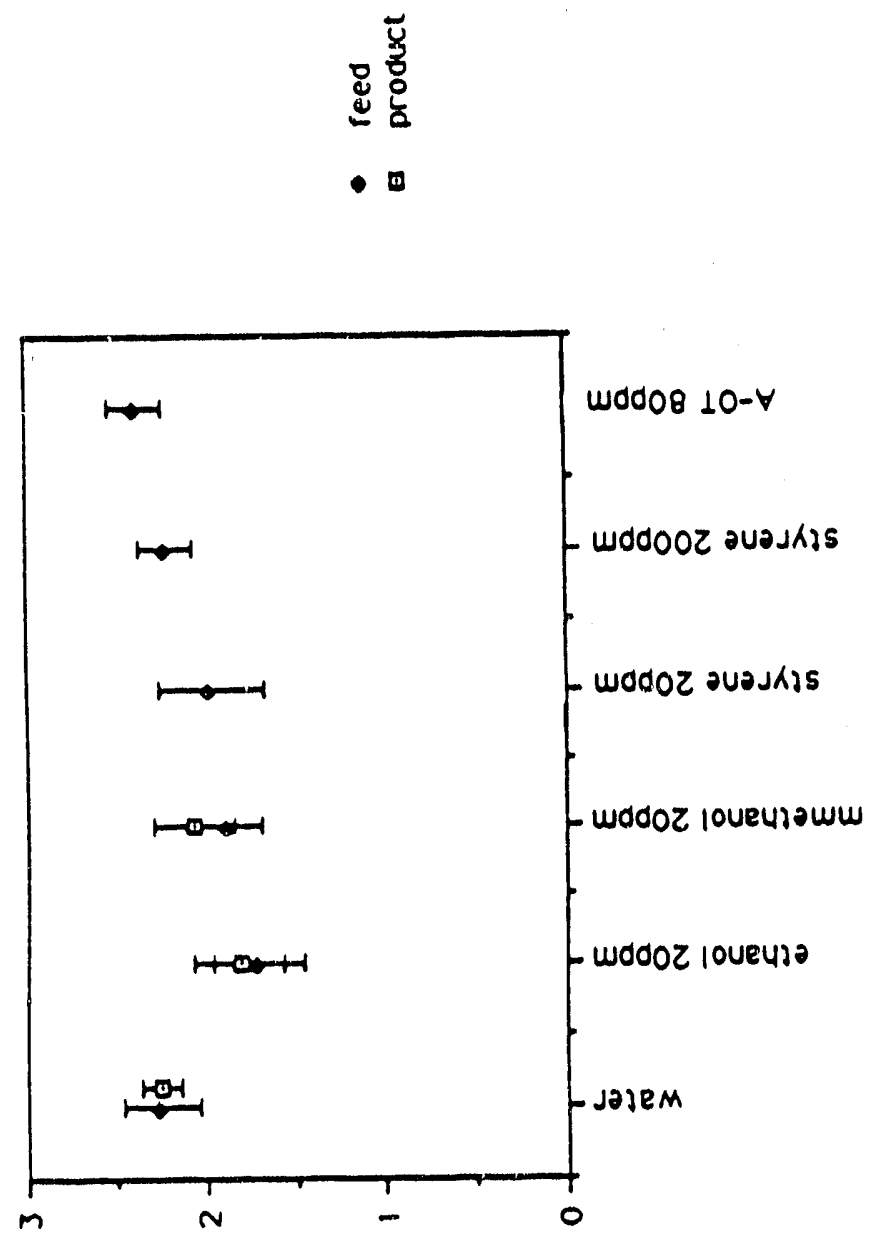

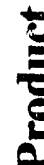

를

छ

占 6

훙을

○ิ 를

응 종

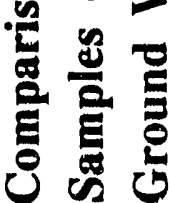

XJPUI VOIJEDIXO

ํ. 


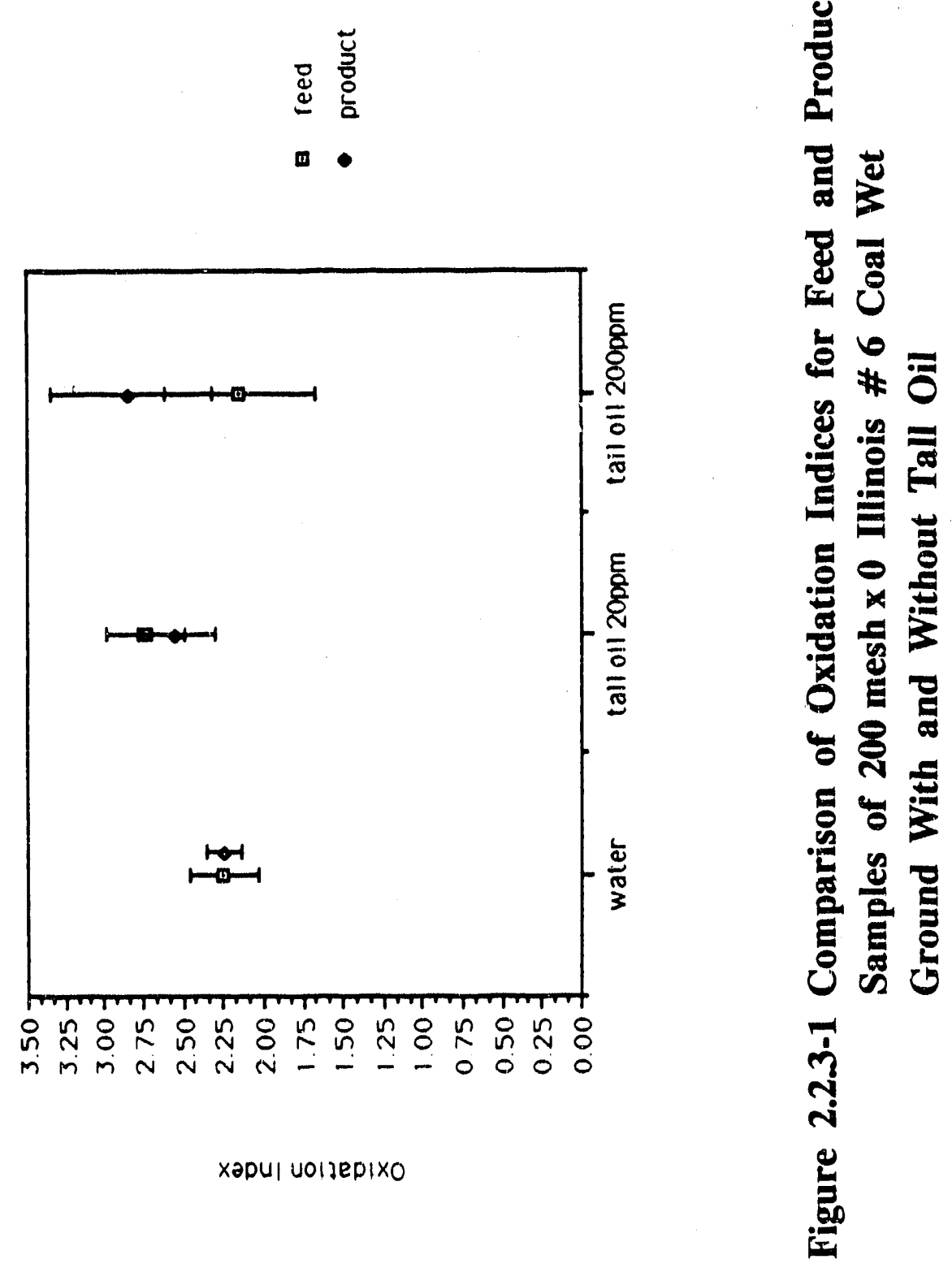



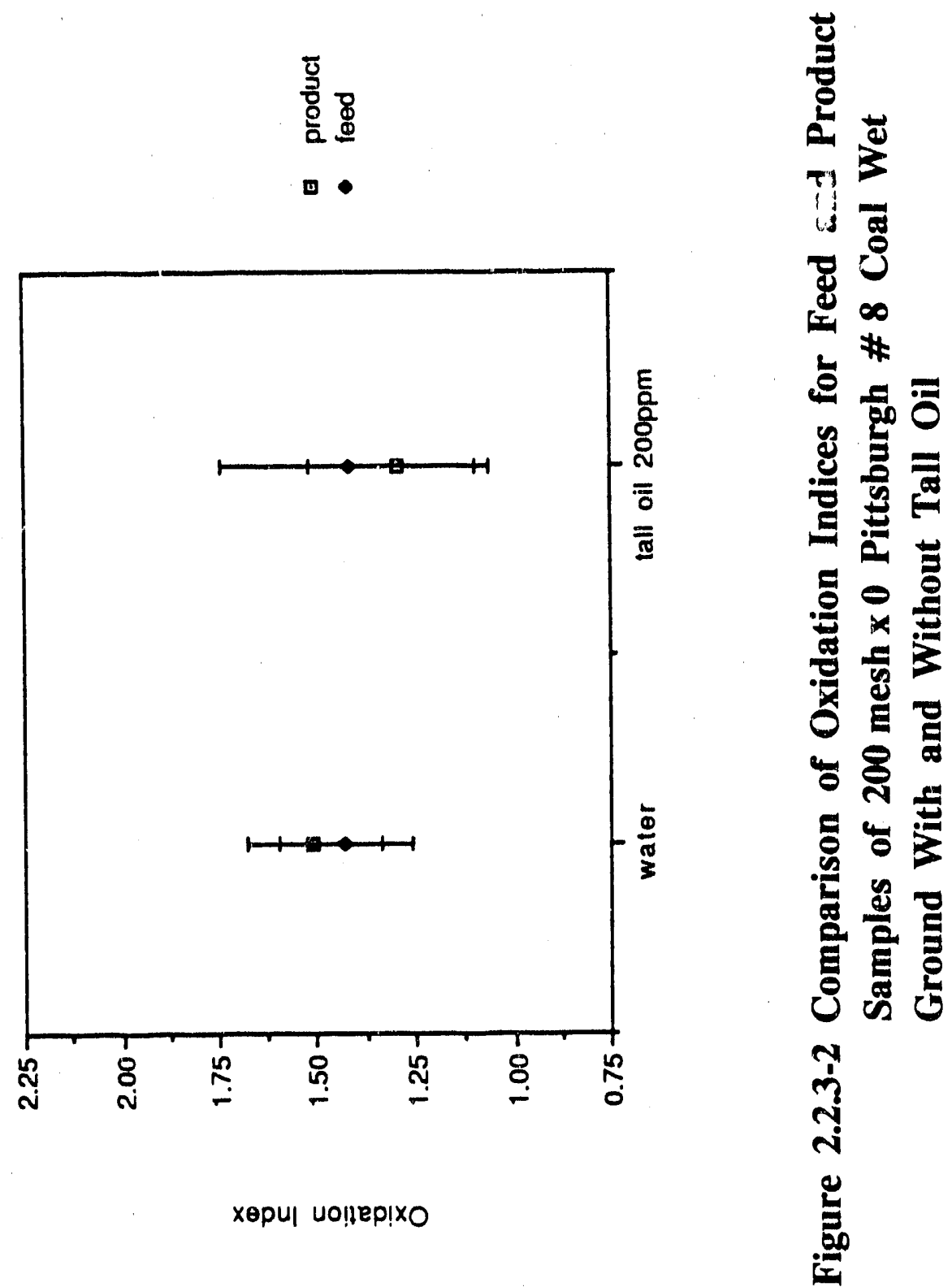


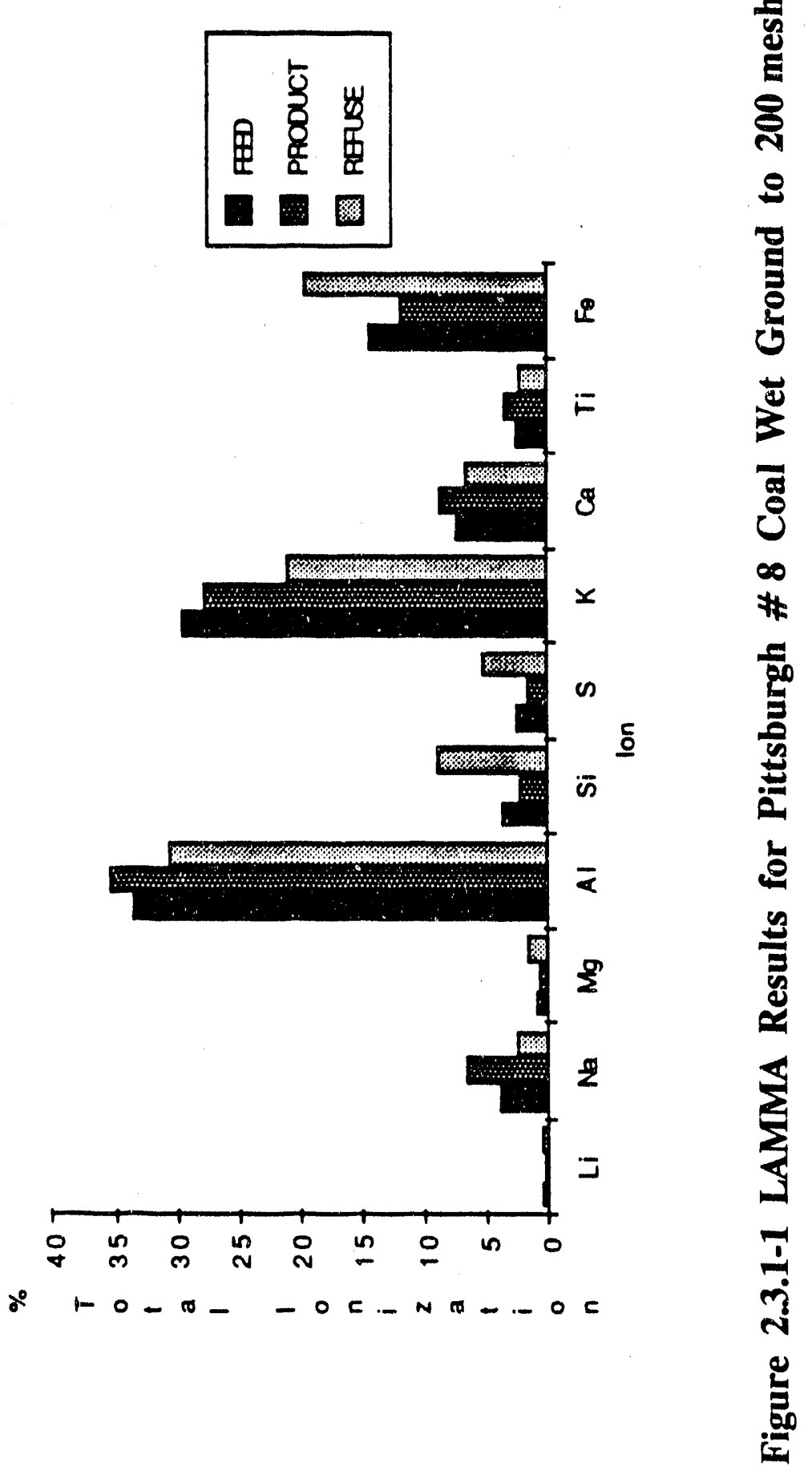




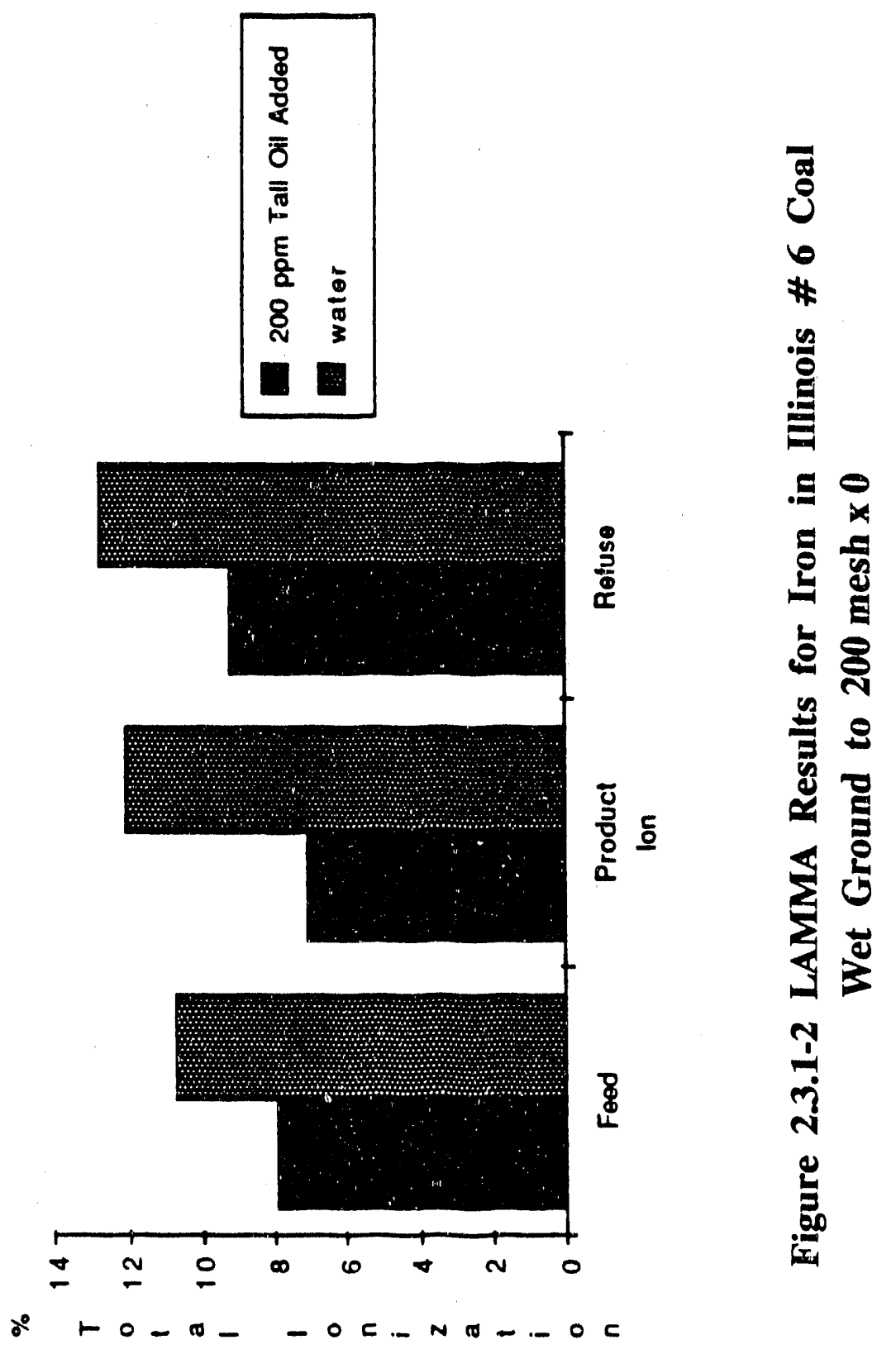




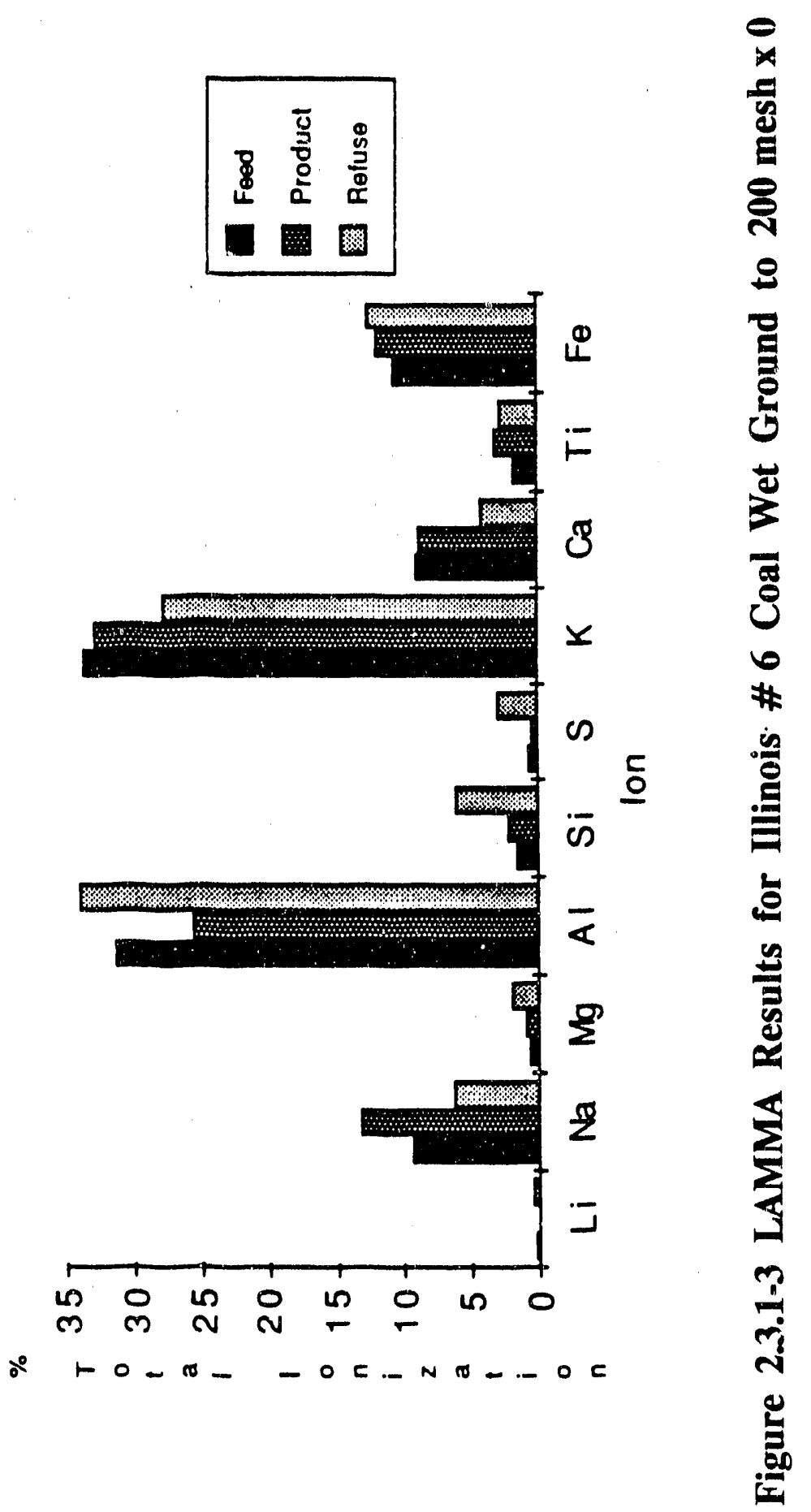




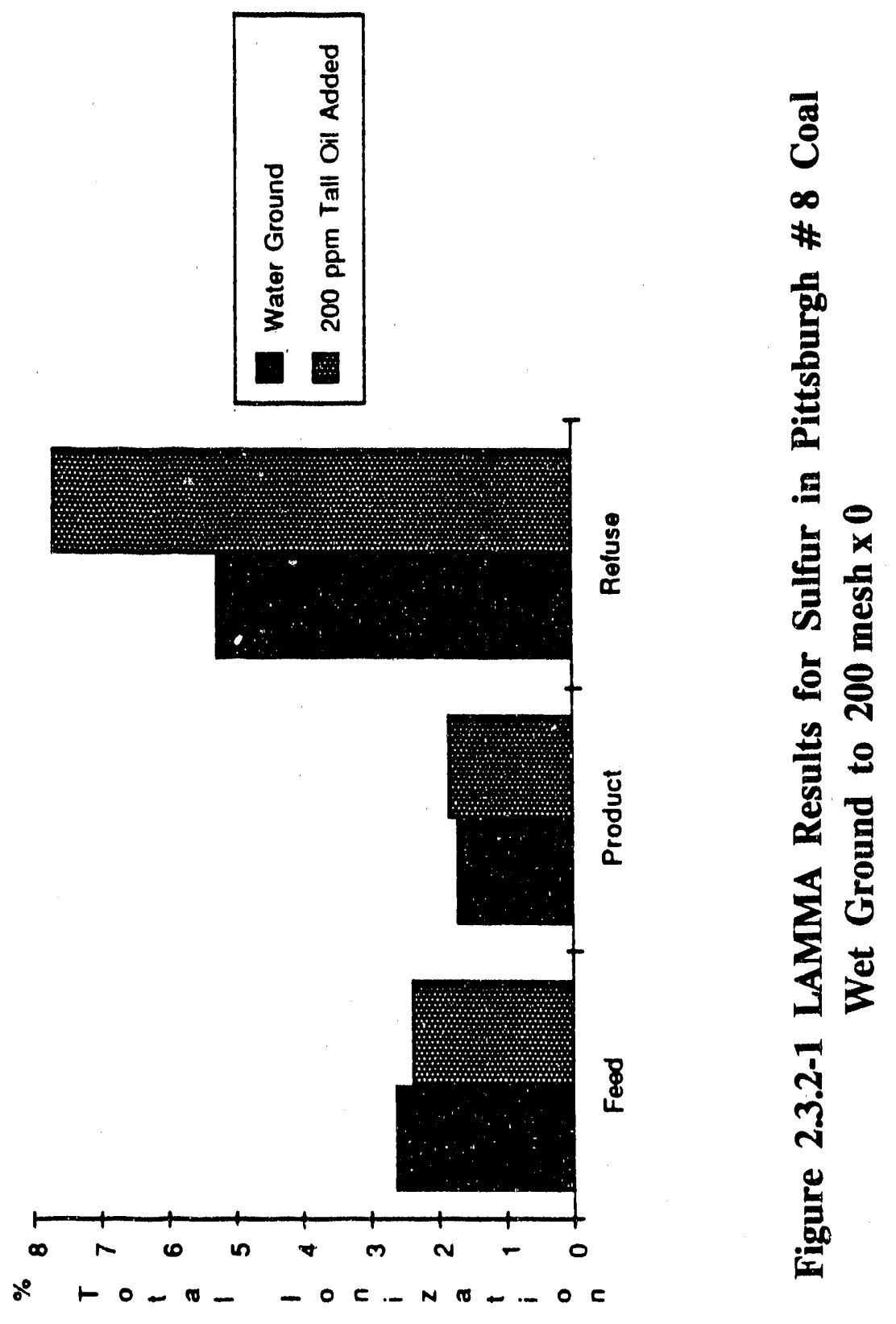




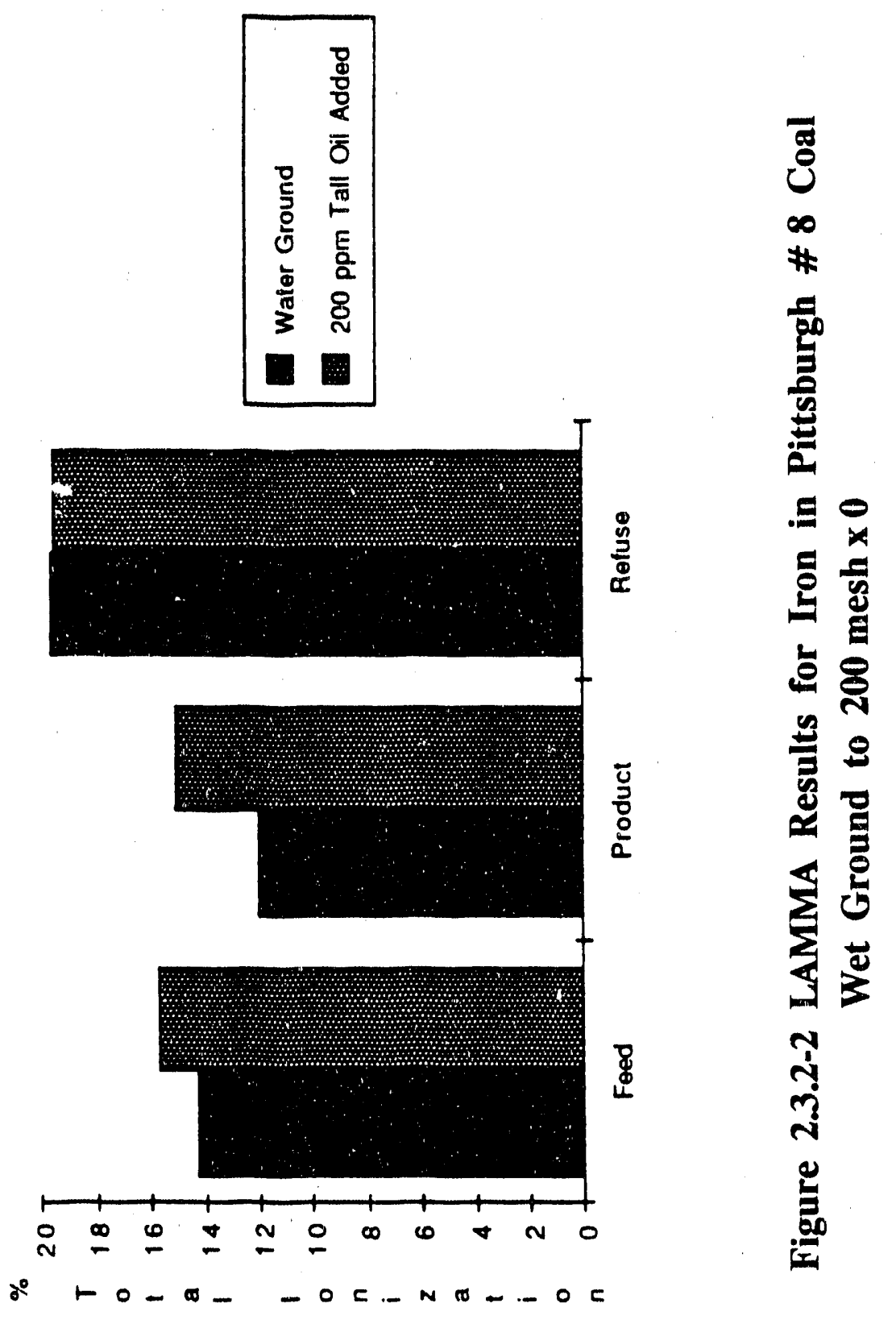




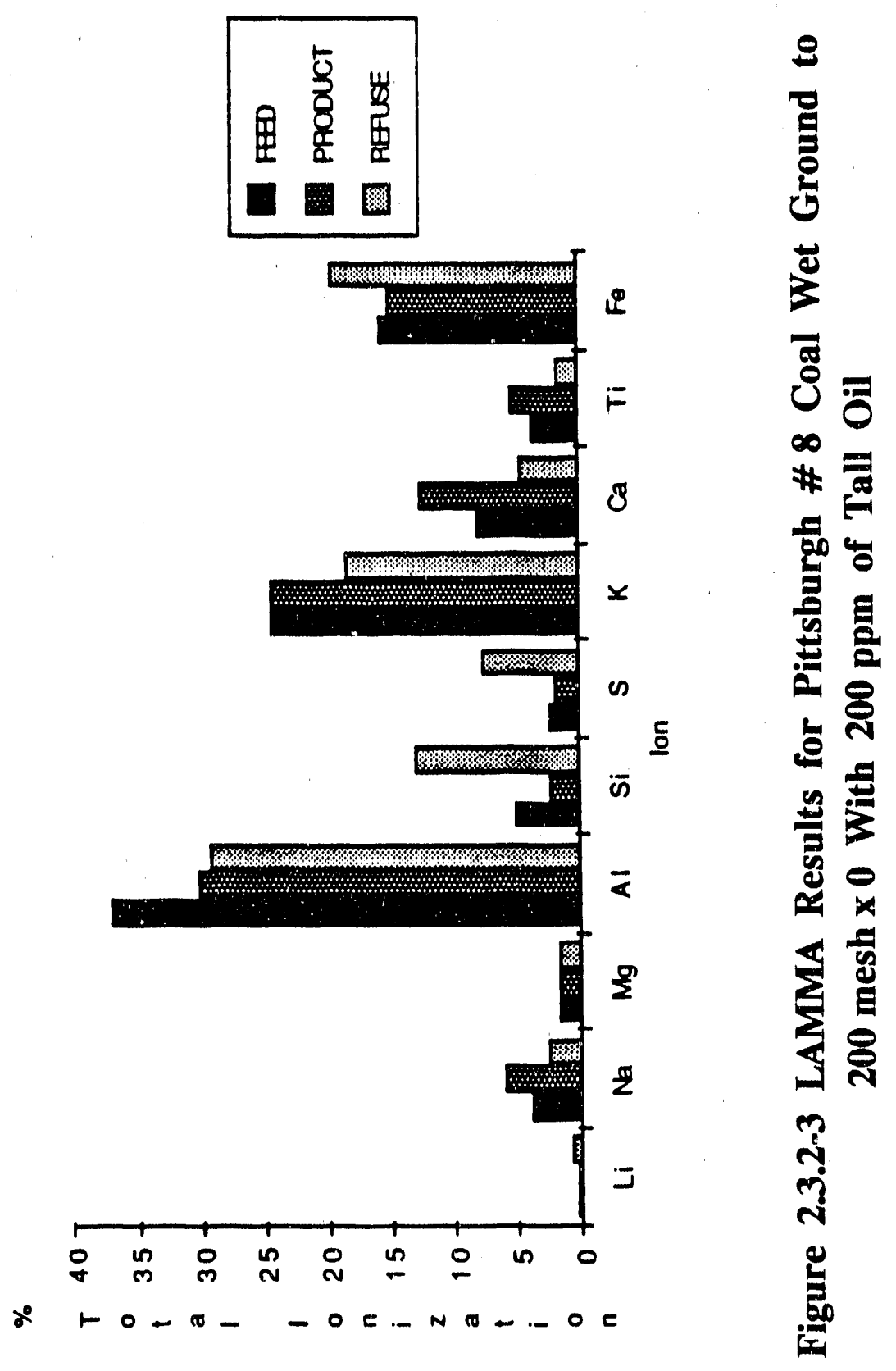



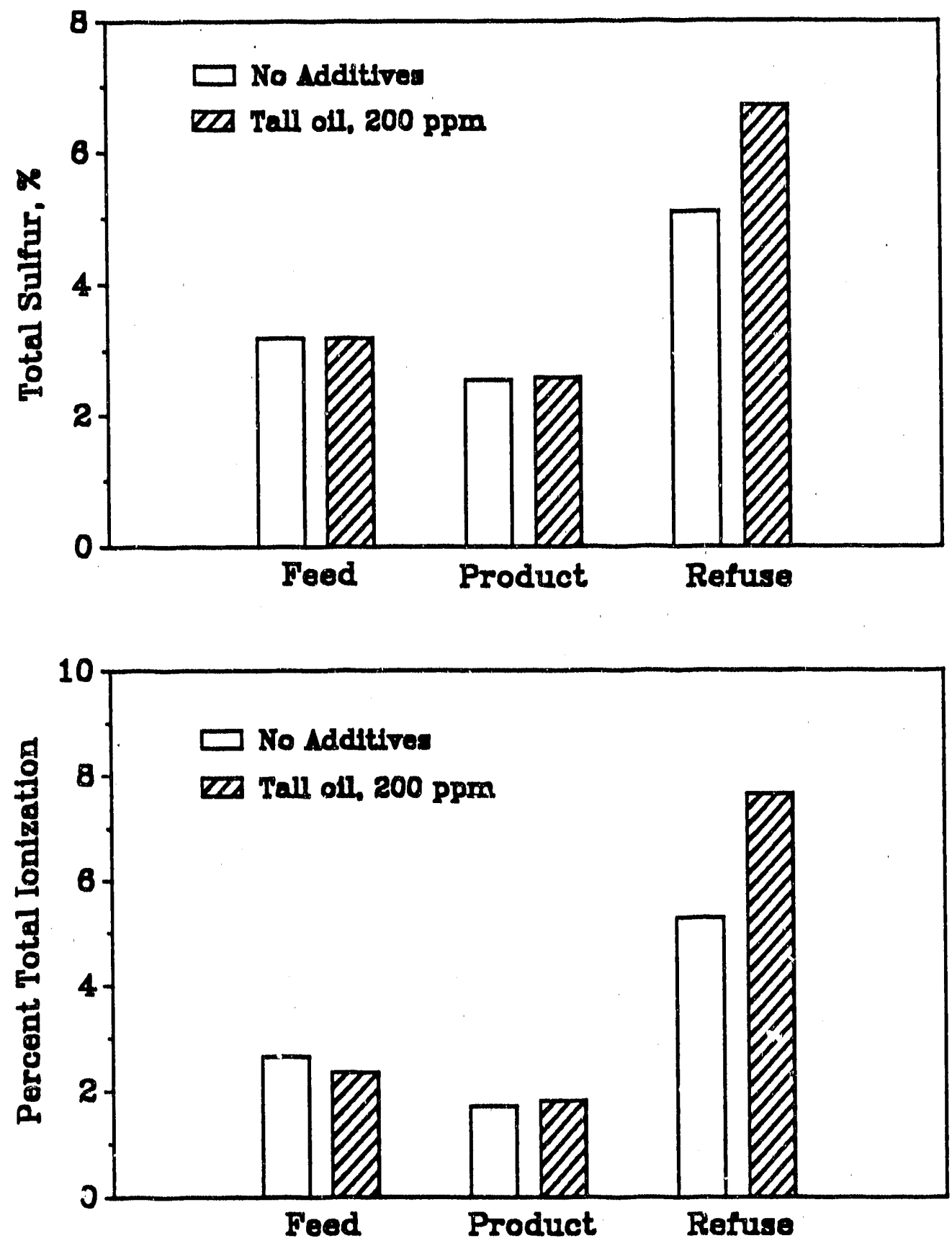

Figure 2.3.2-4 Comparison Between Agglomeration Results and LAMMA Data for Pittsburgh \# 8 Coal 


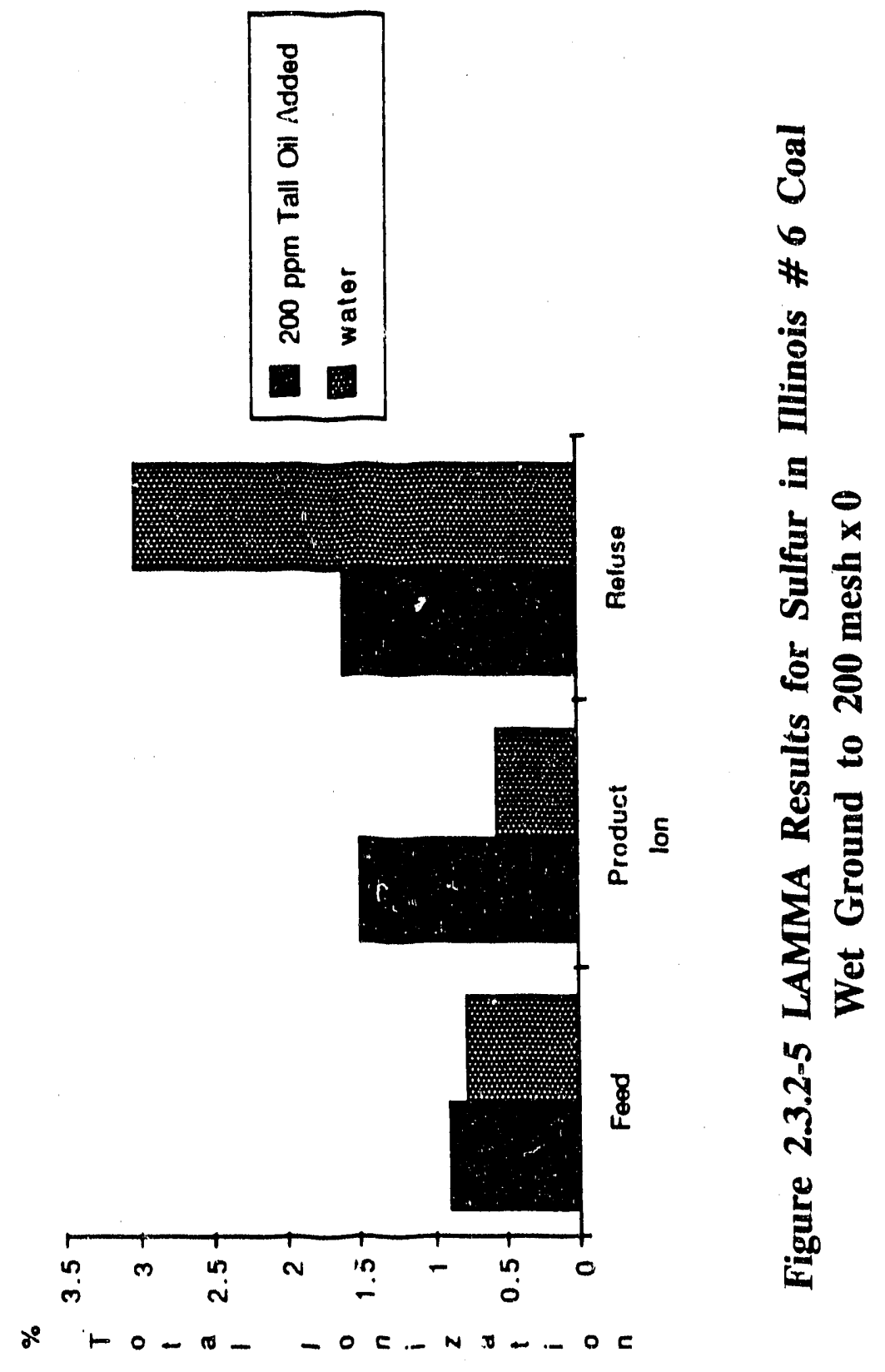




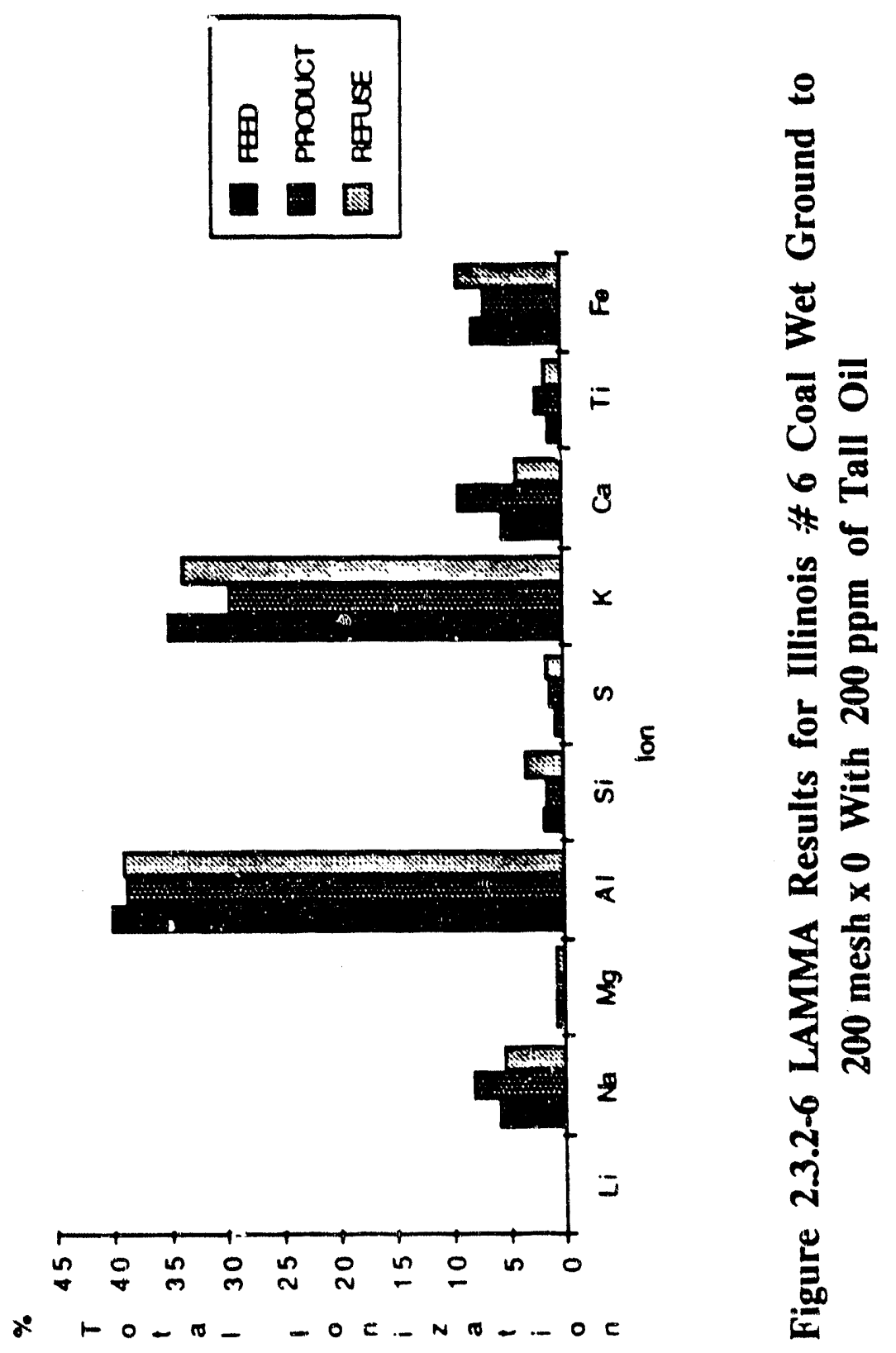




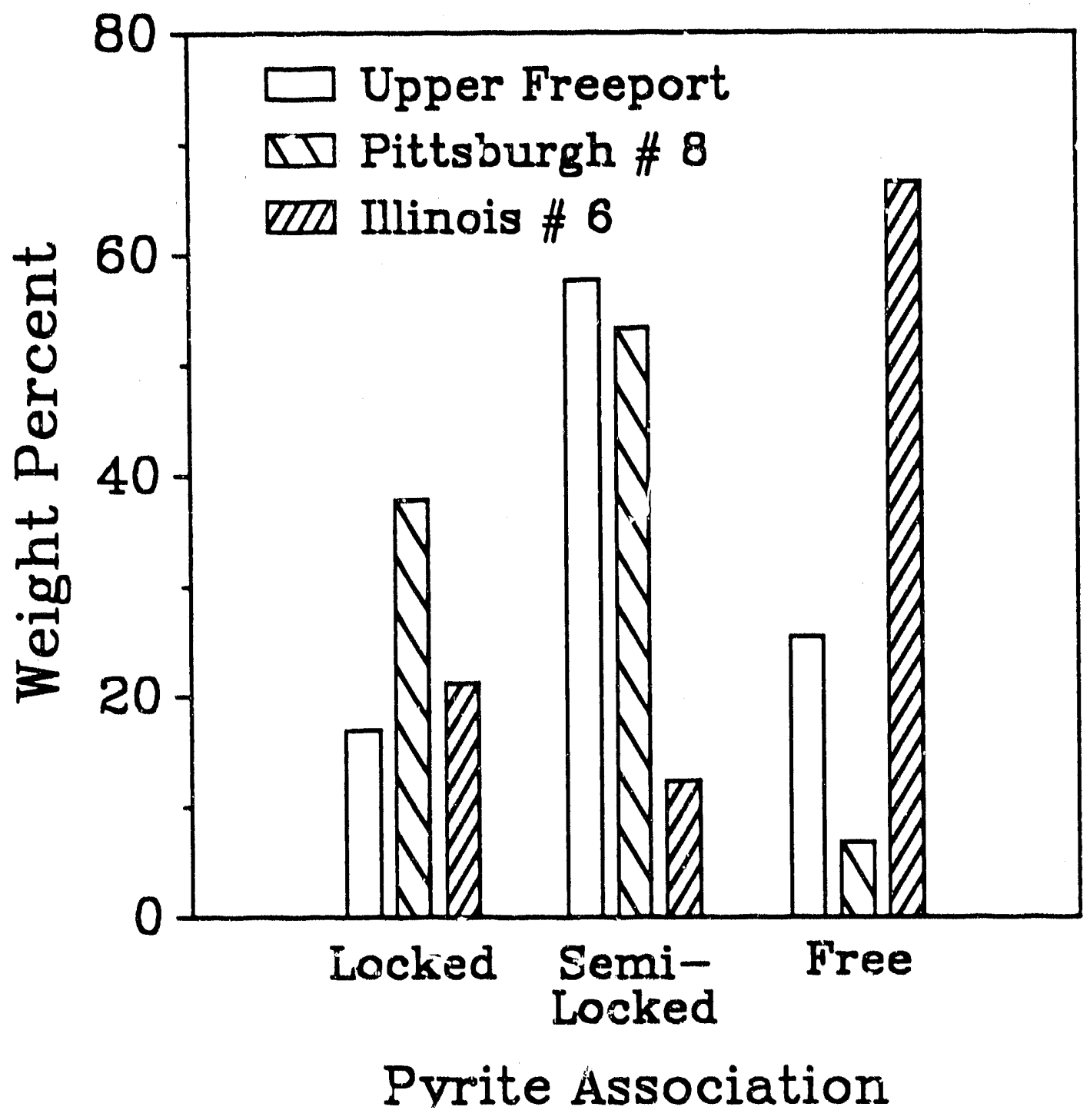

Figure 2.8-1 Pyrite Association for 28 mesh x 0 Samples 


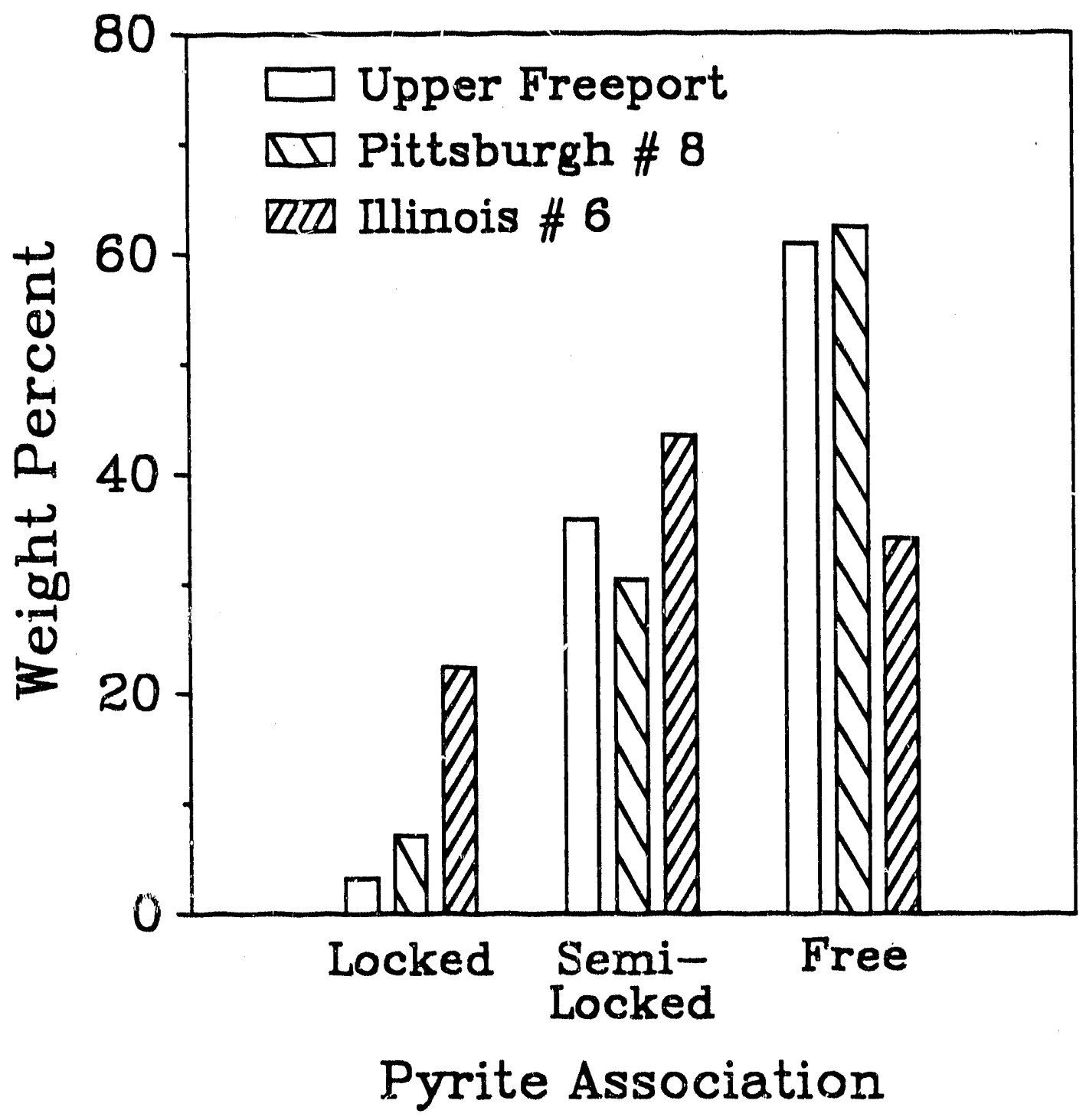

Figure 2.8-2 Pyrite Association for 200 mesh x 0 Samples 


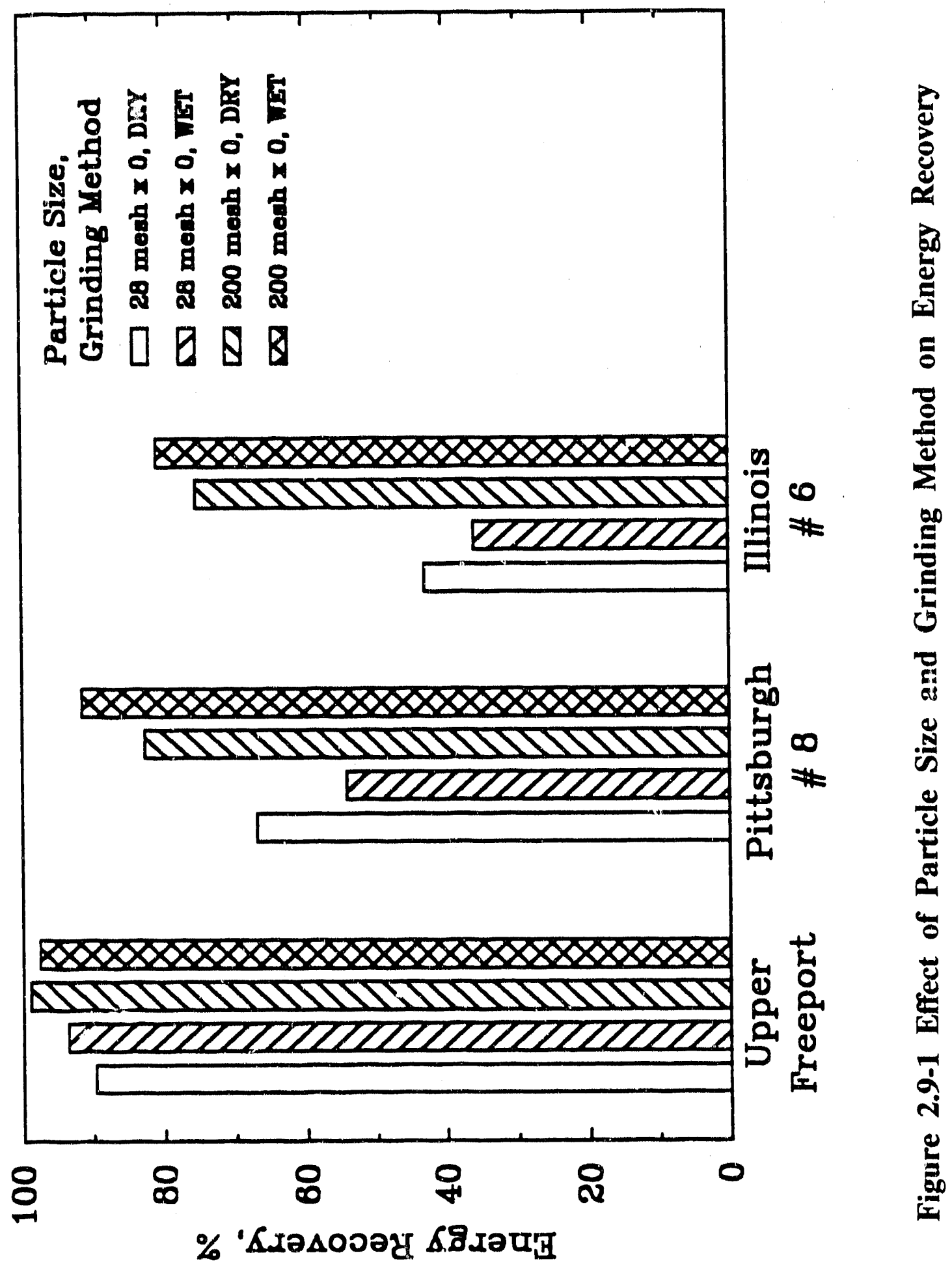




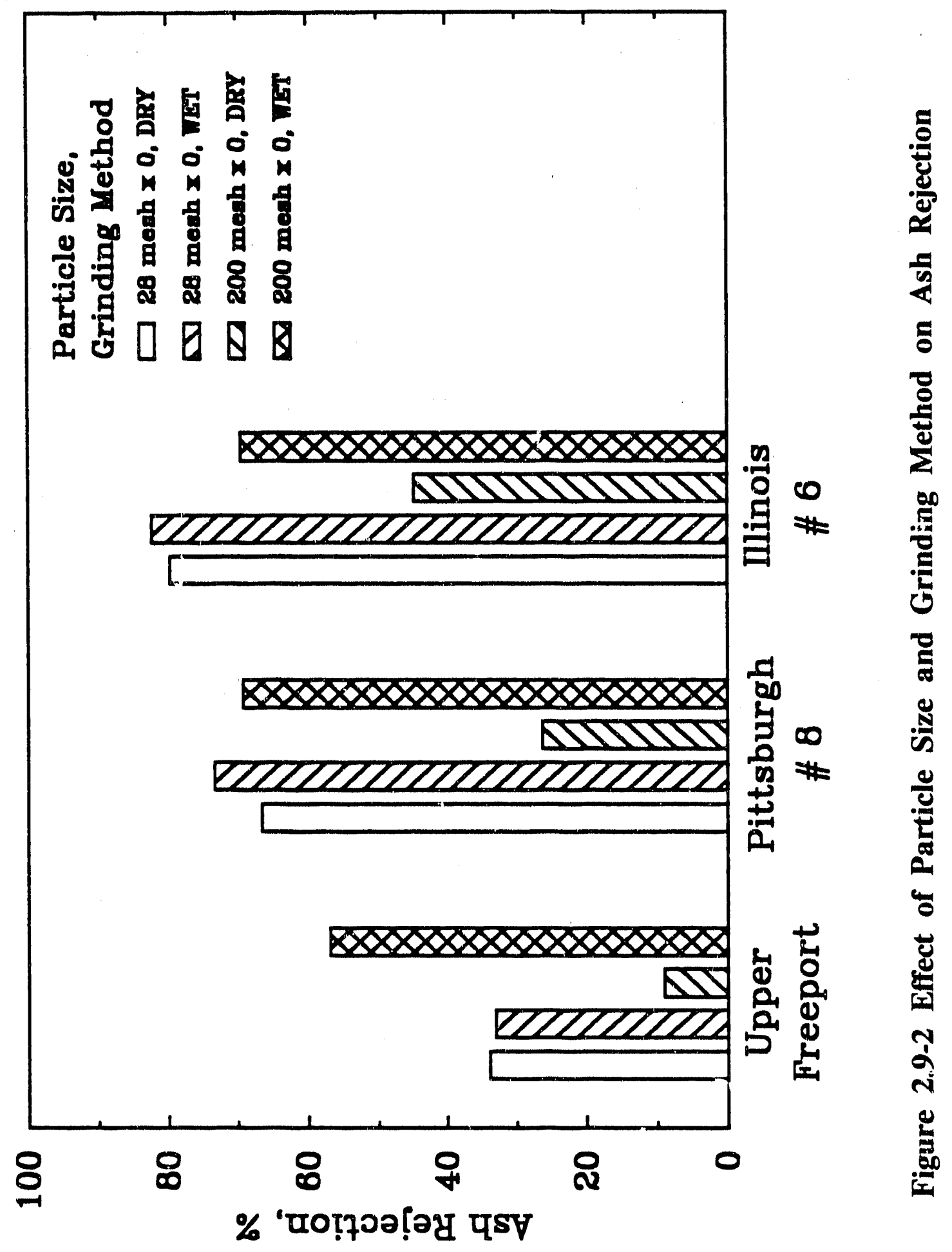




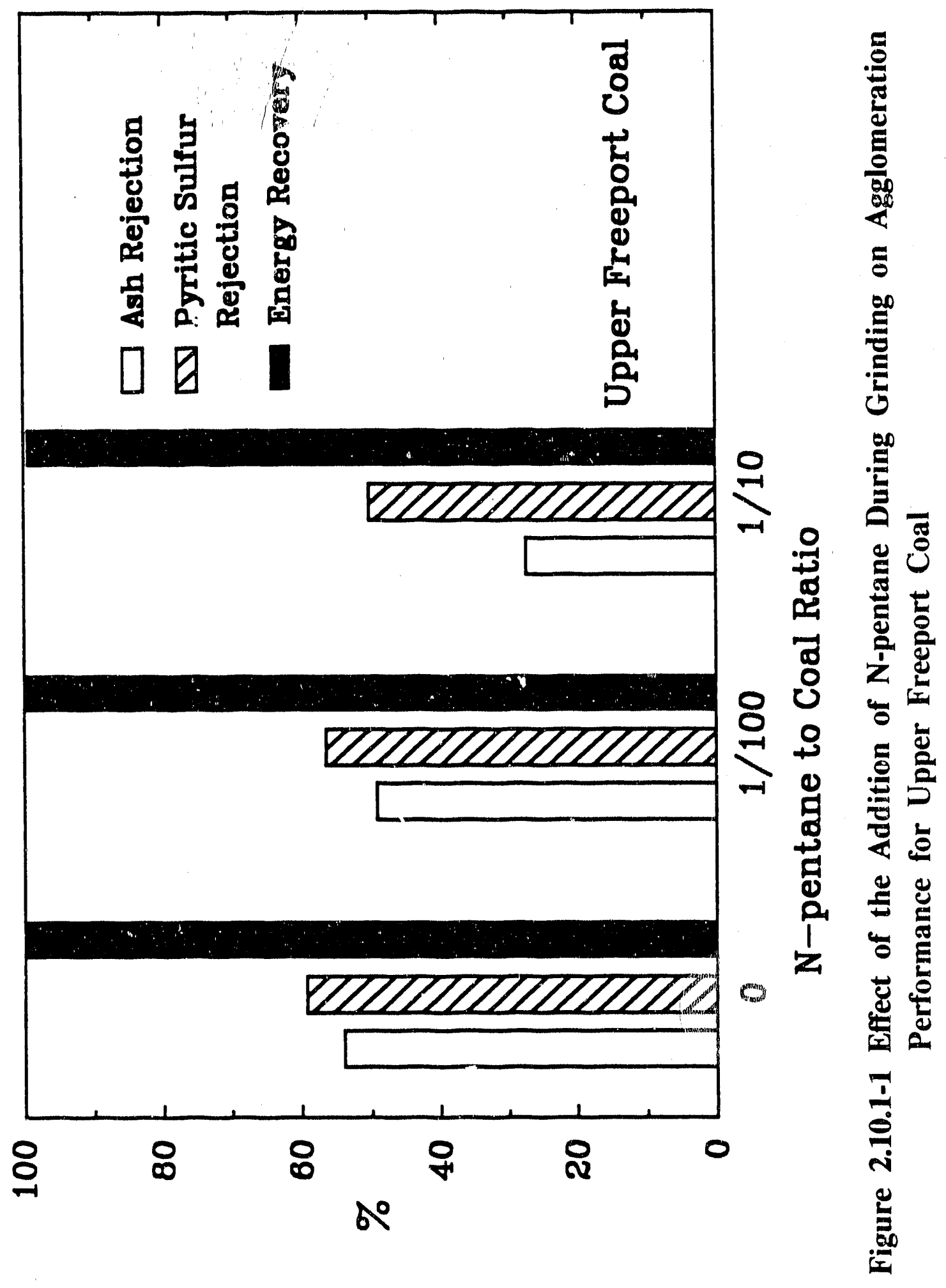




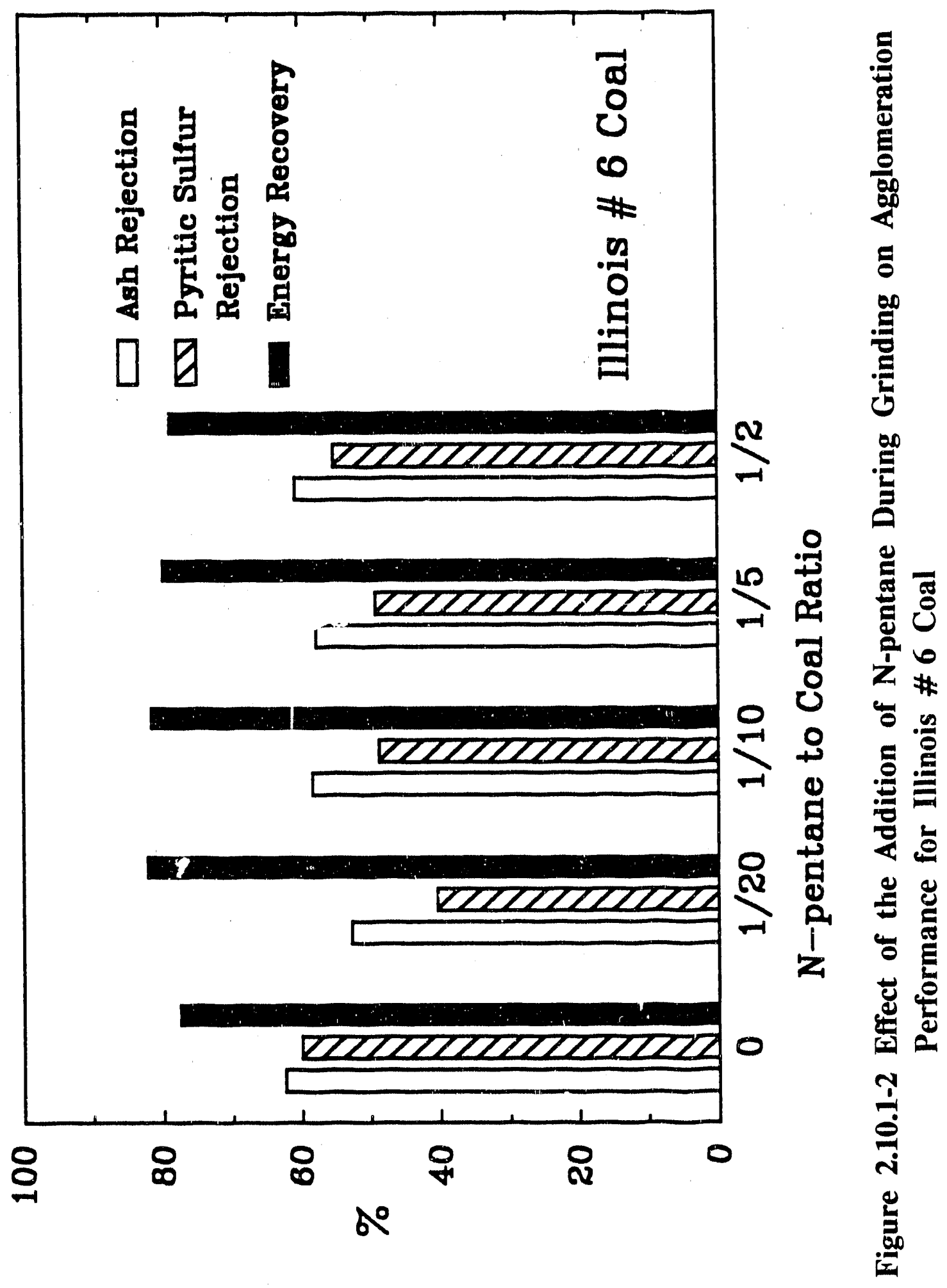




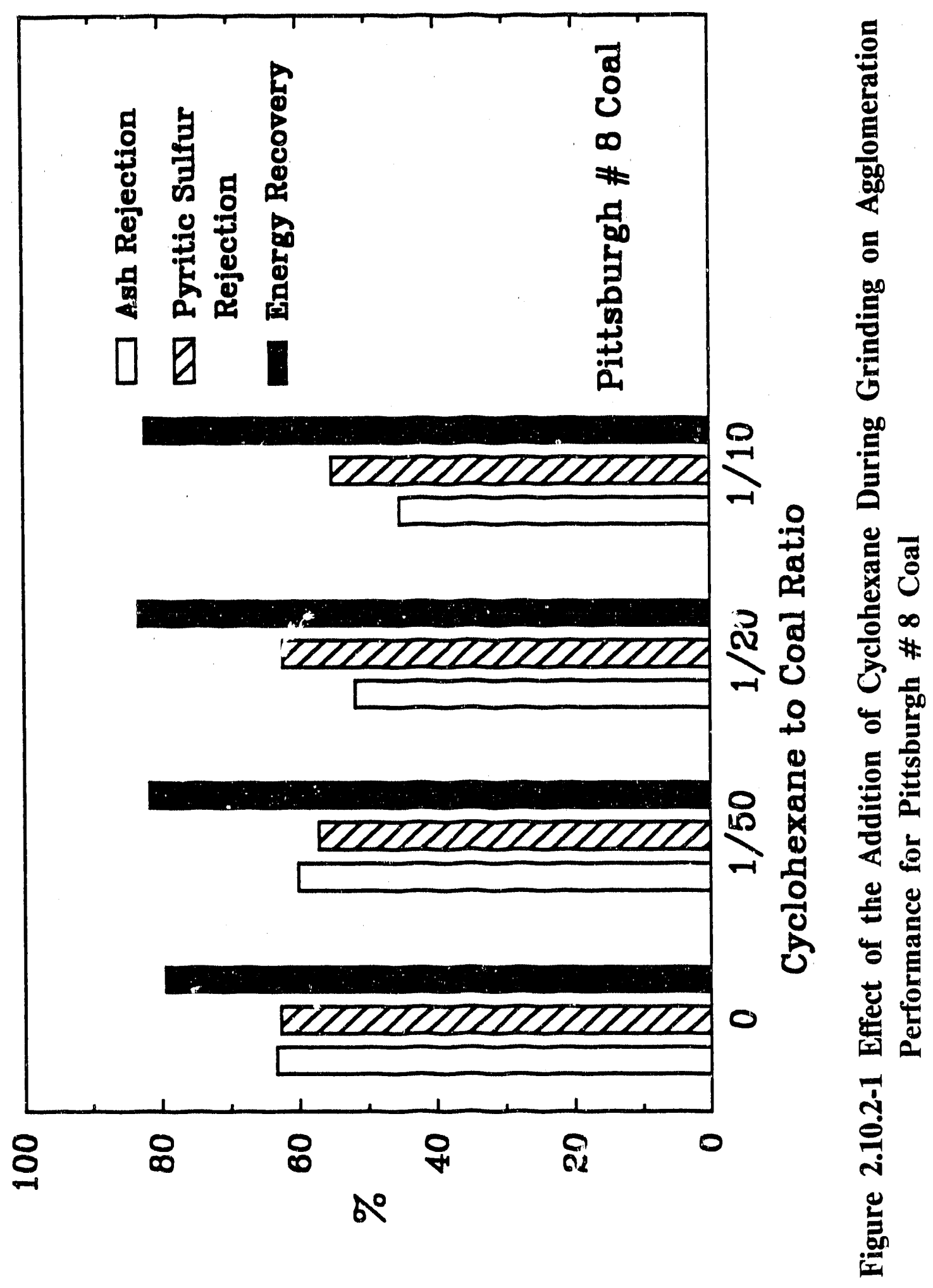




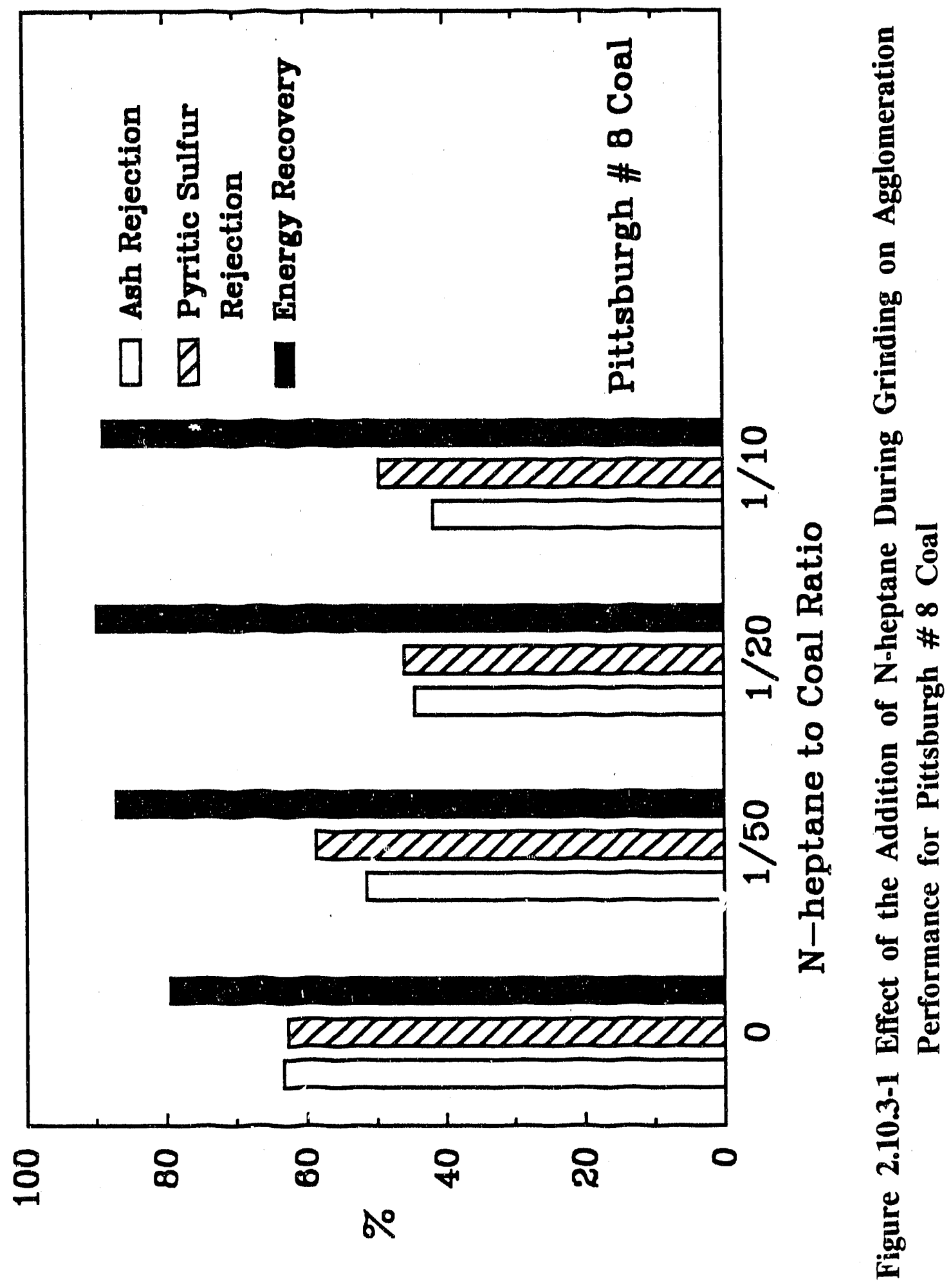




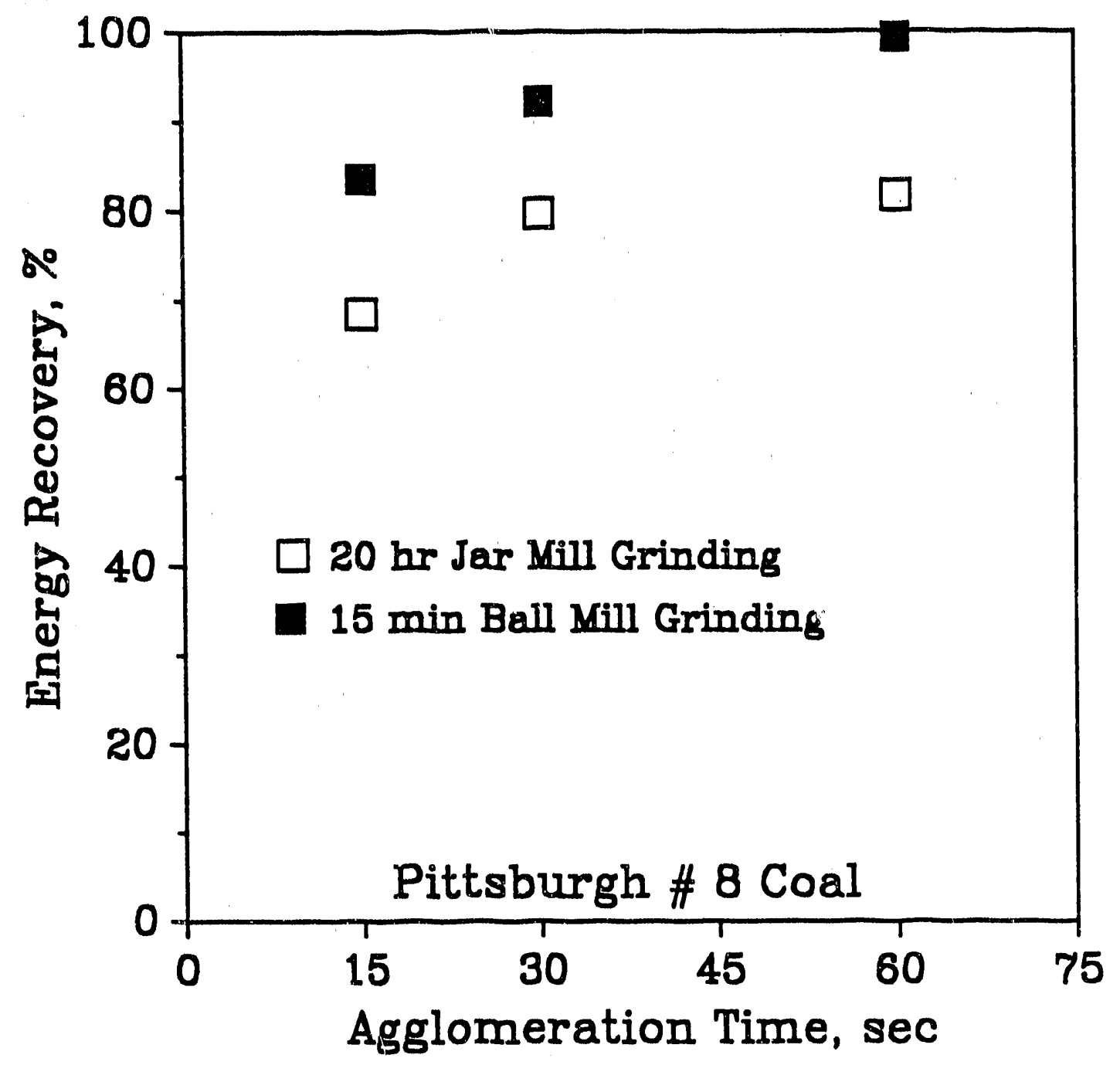

Figure 2.11.1-1 Effect of Grinding Method on Energy Recovery for Pittsburgh \# 8 Coal 


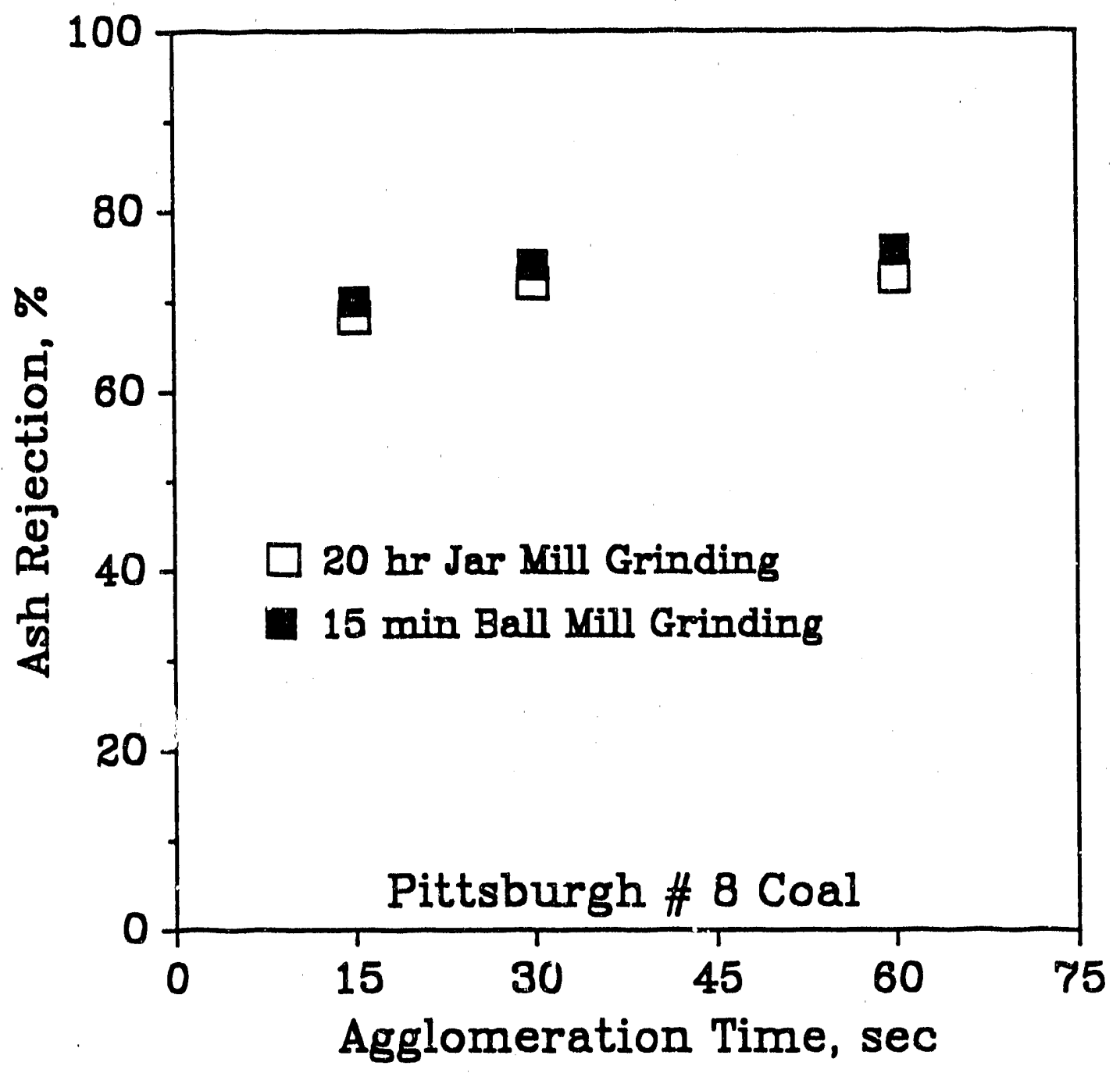

Figure 2.11.1-2 Effect of Grinding Method on Ash Rejection for Pittsburgh \# 8 Coal 


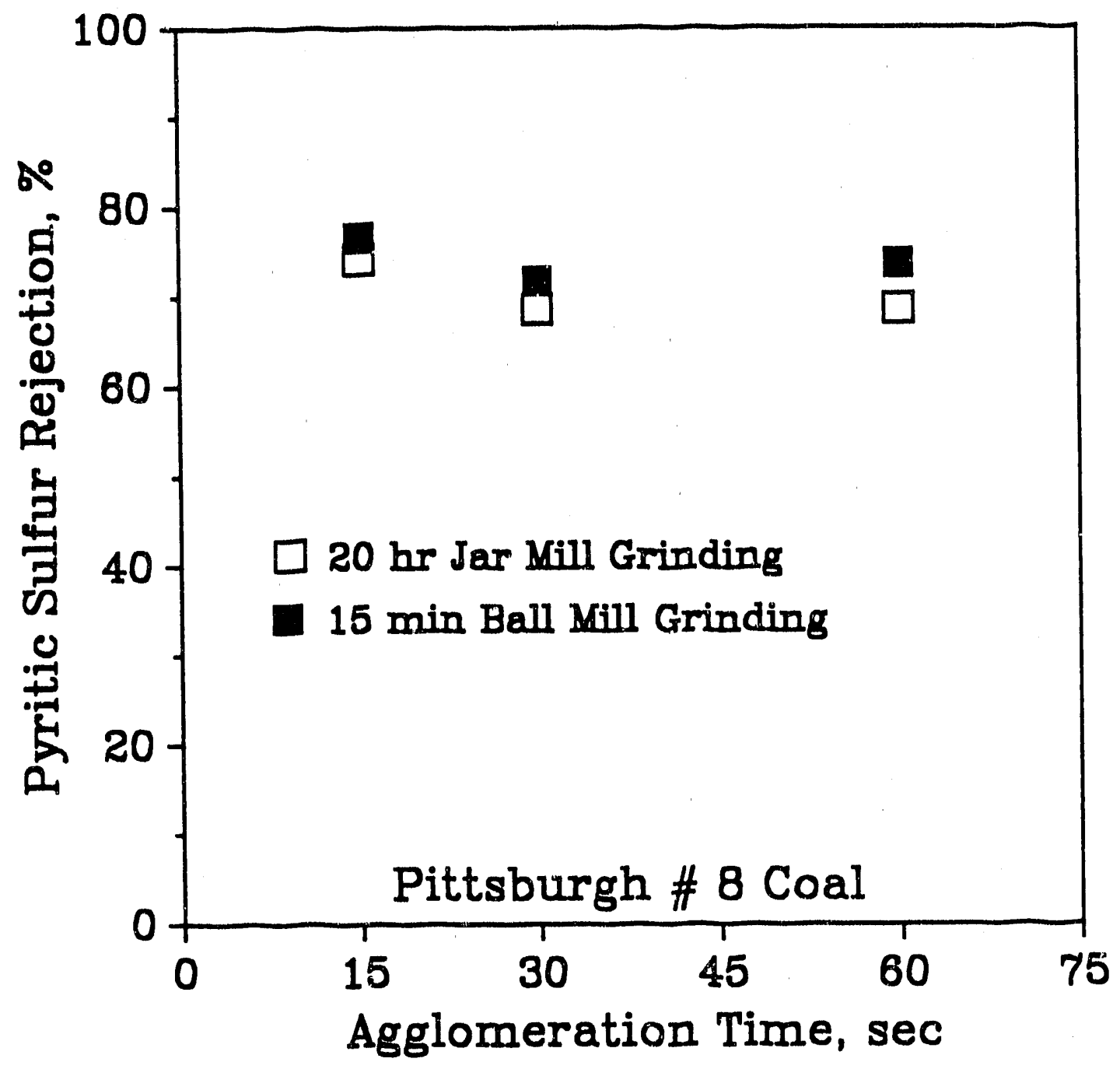

Figure 2.11.1-3 Effect of Grinding Method on Pyritic Sulfur Rejection for Pittsburgh \# 8 Coal 
Weight Percent Distribution

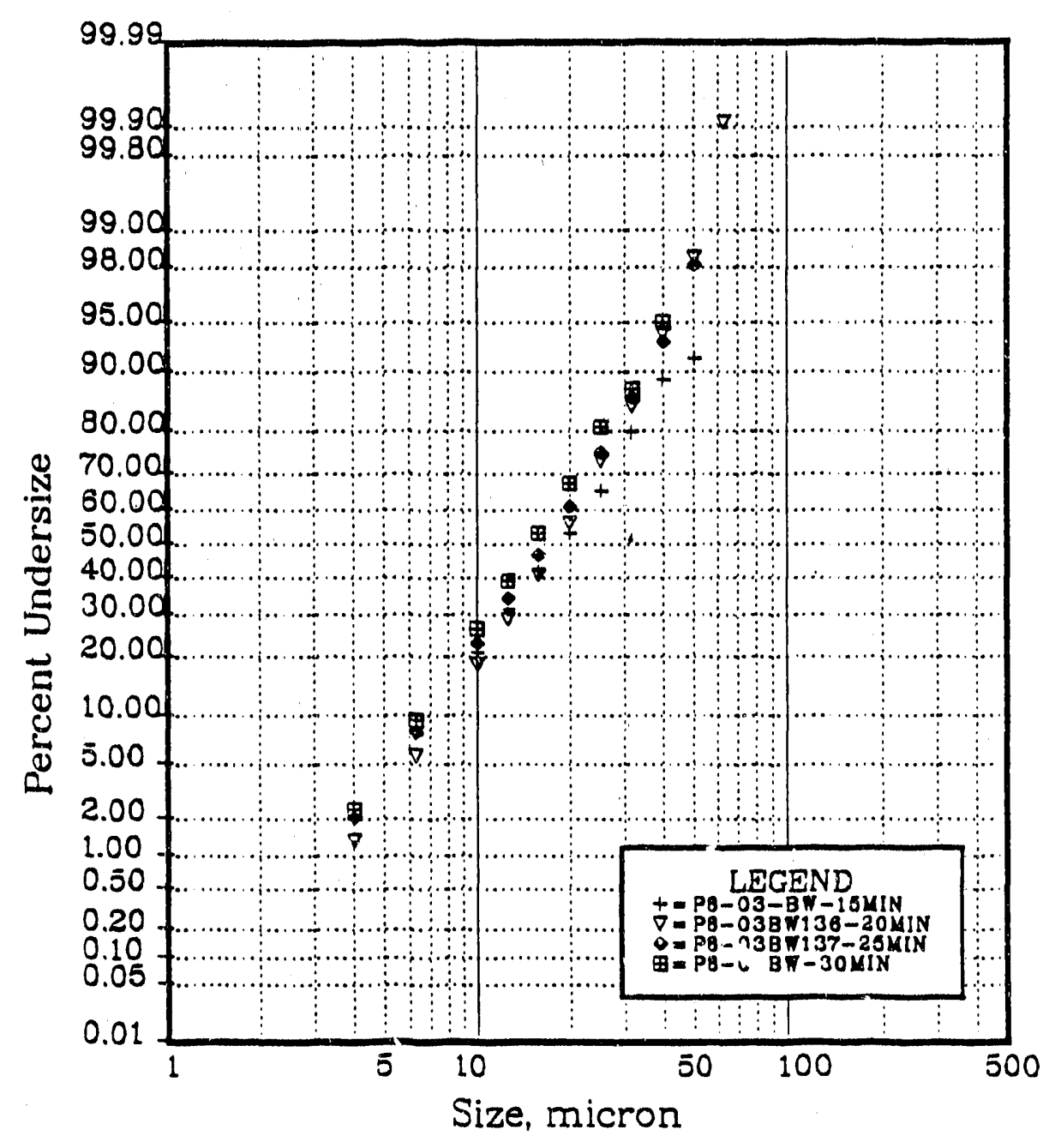

Figure 2.11.2-1 Effect of Grinding Time on Particle Size for Pittsburgh \# 8 Coal 


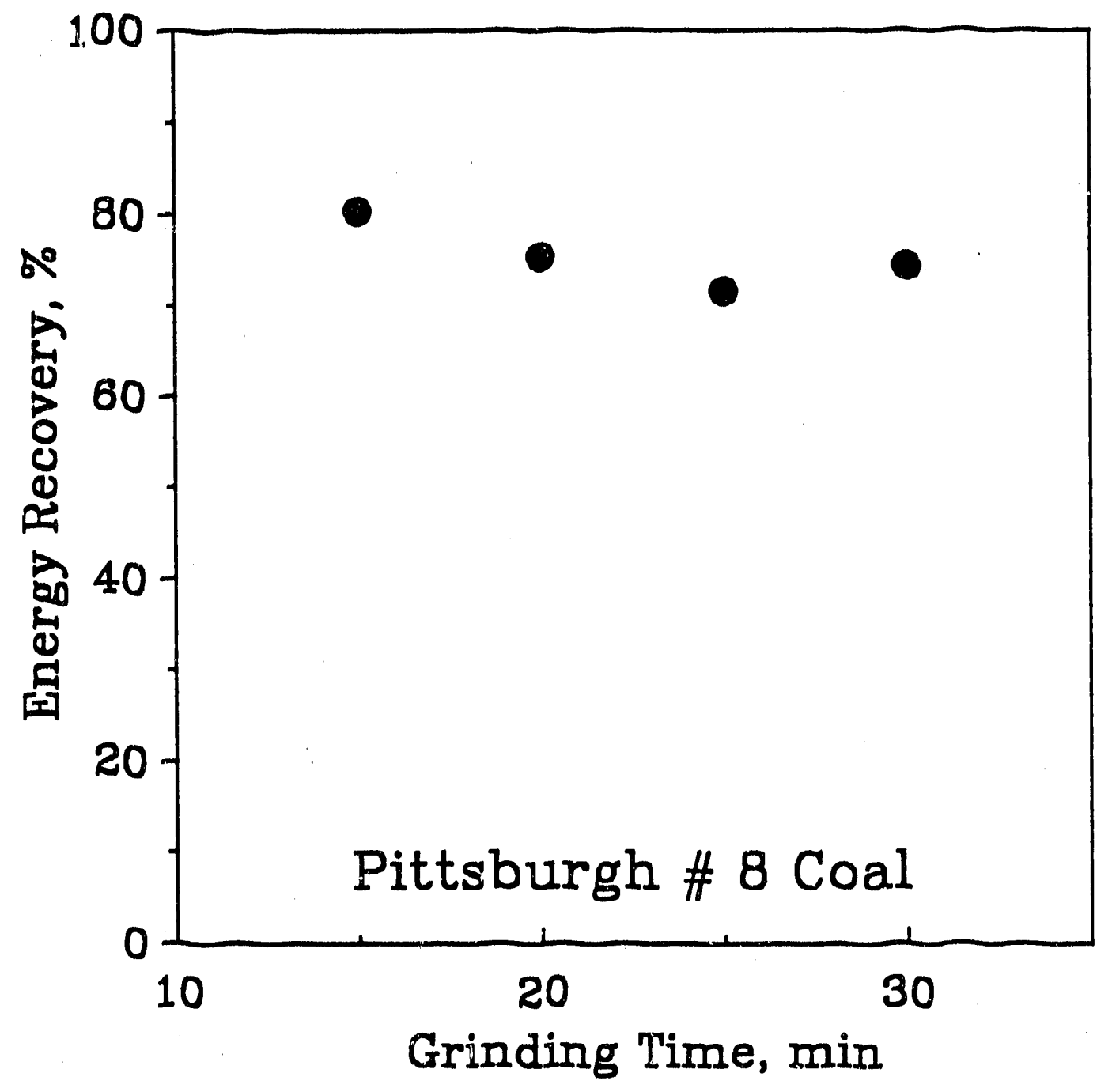

Figure 2.11.2-2 Effect of Grinding Time on Energy Recovery for Pittsburgh \# 8 Coal 


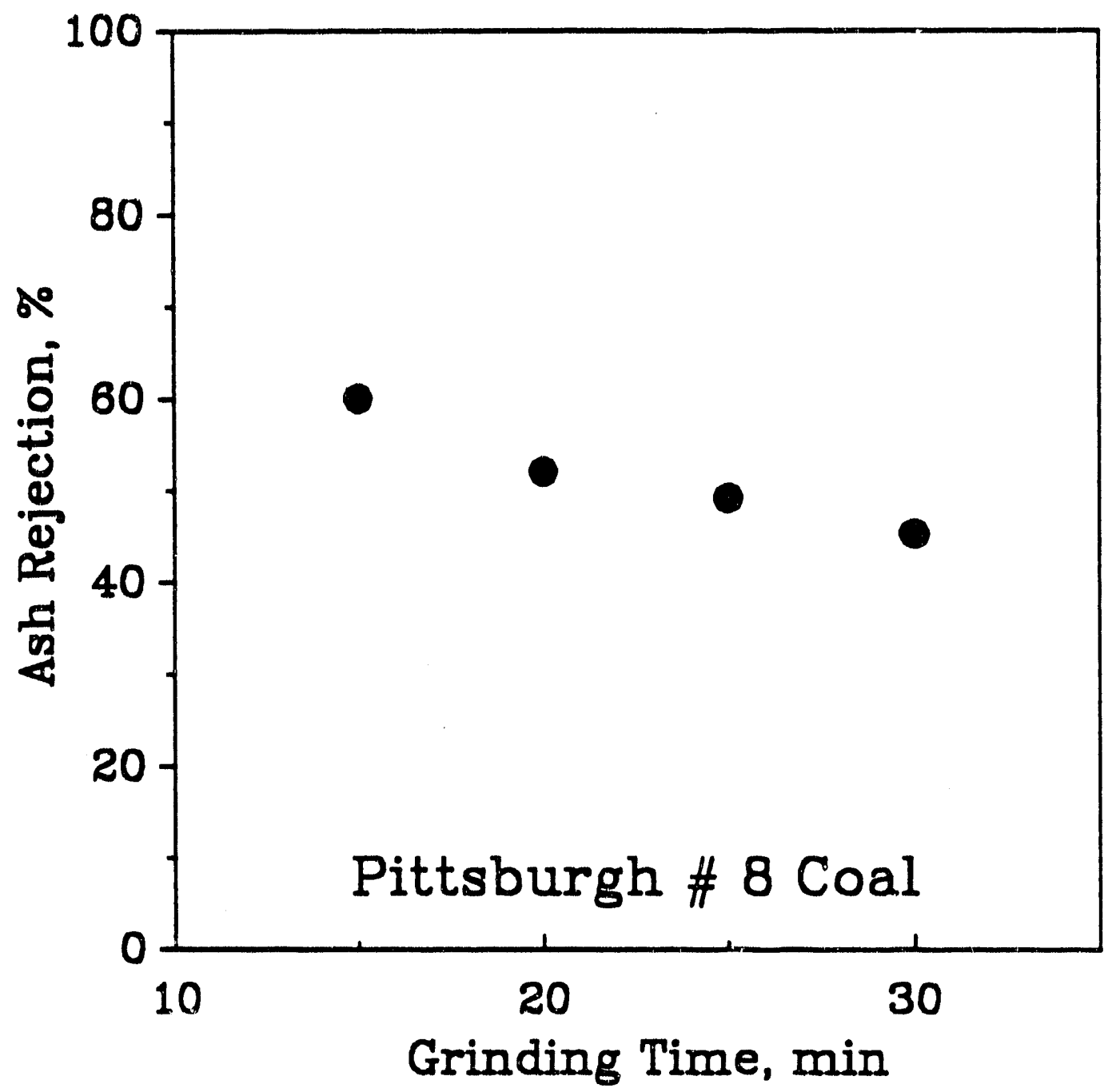

Figure 2.11.2-3 Effect of Grinding Time on Ash Rejection for Pittsburgh \# 8 Coal 


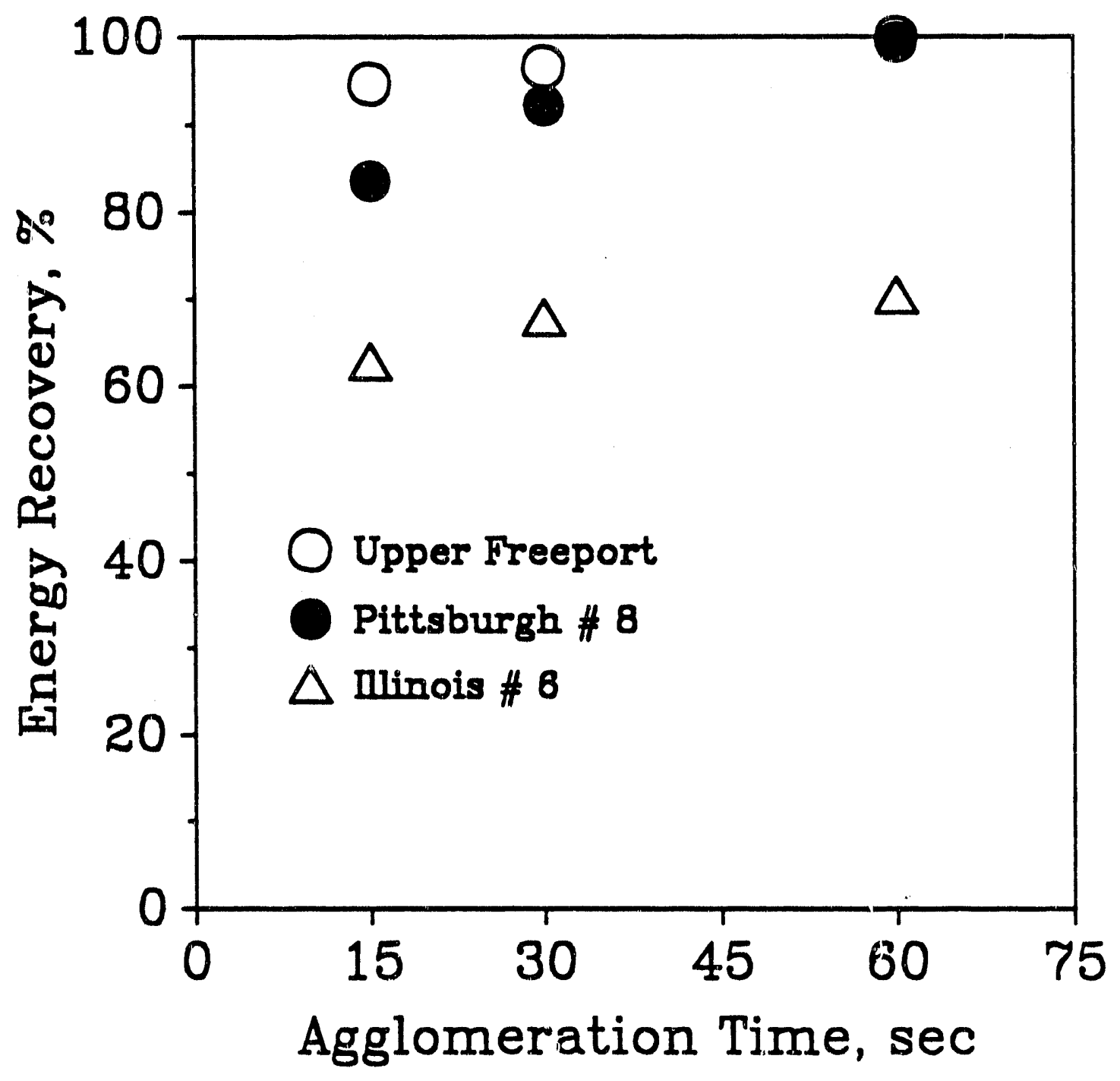

Figure 2.11.3-1 Effect of Agglomeration Time on Energy Recovery 


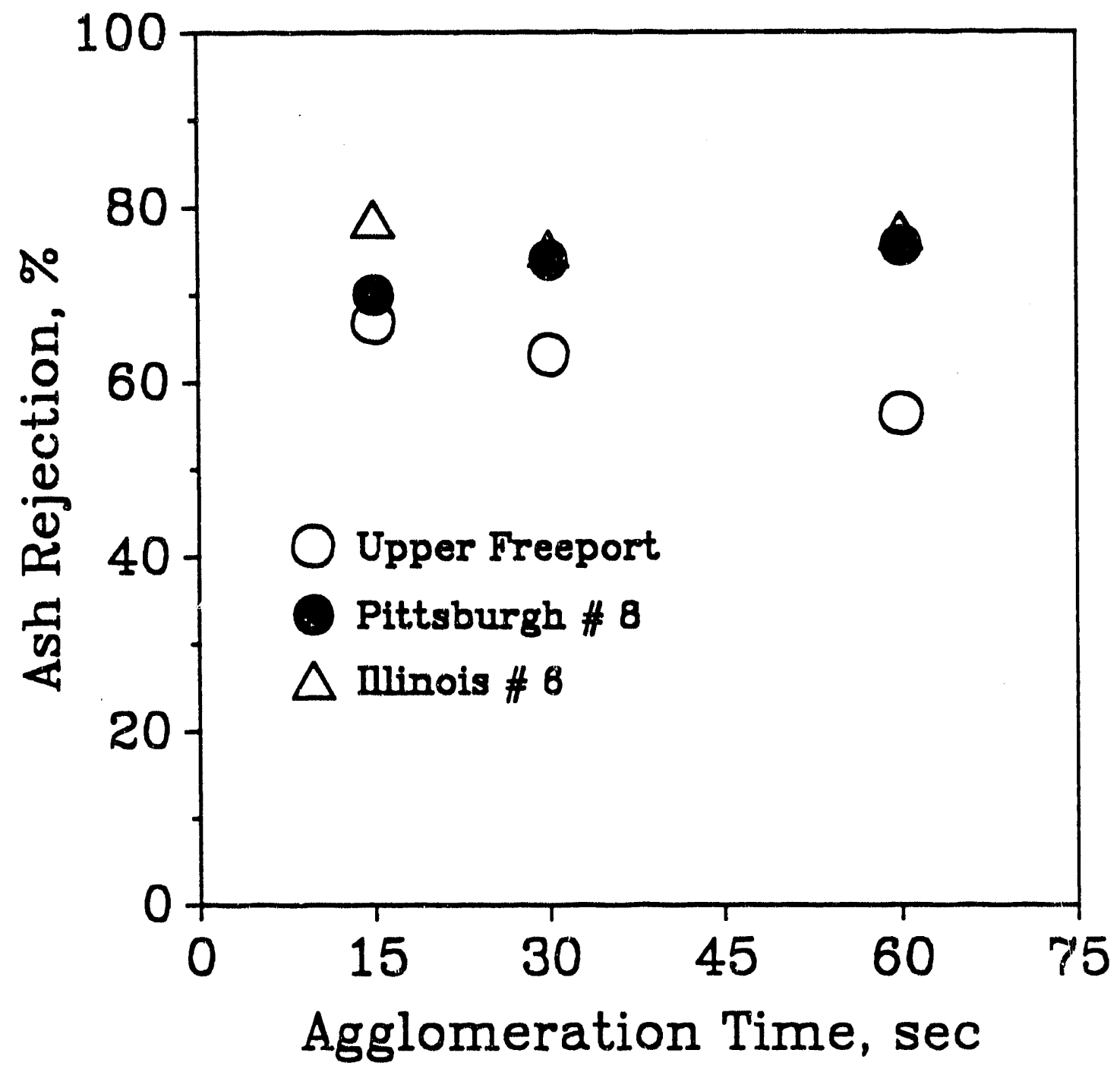

Figure 2.11.3-2 Effect of Agglomeration Time on Ash Rejectiont 


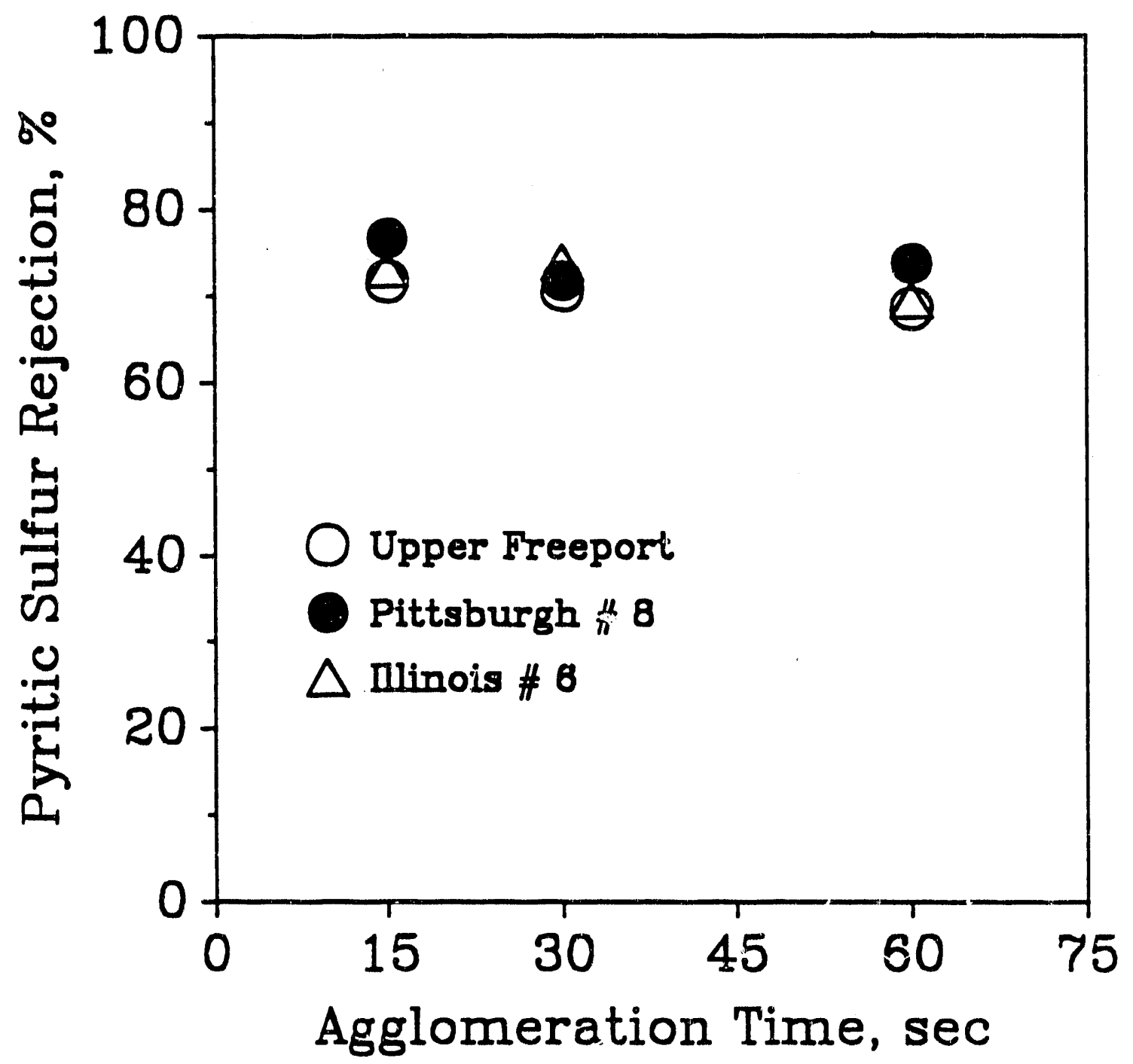

Figure 2.11.3-3 Effect of Agglomeration Time on Pyritic Sulfur Rejection 


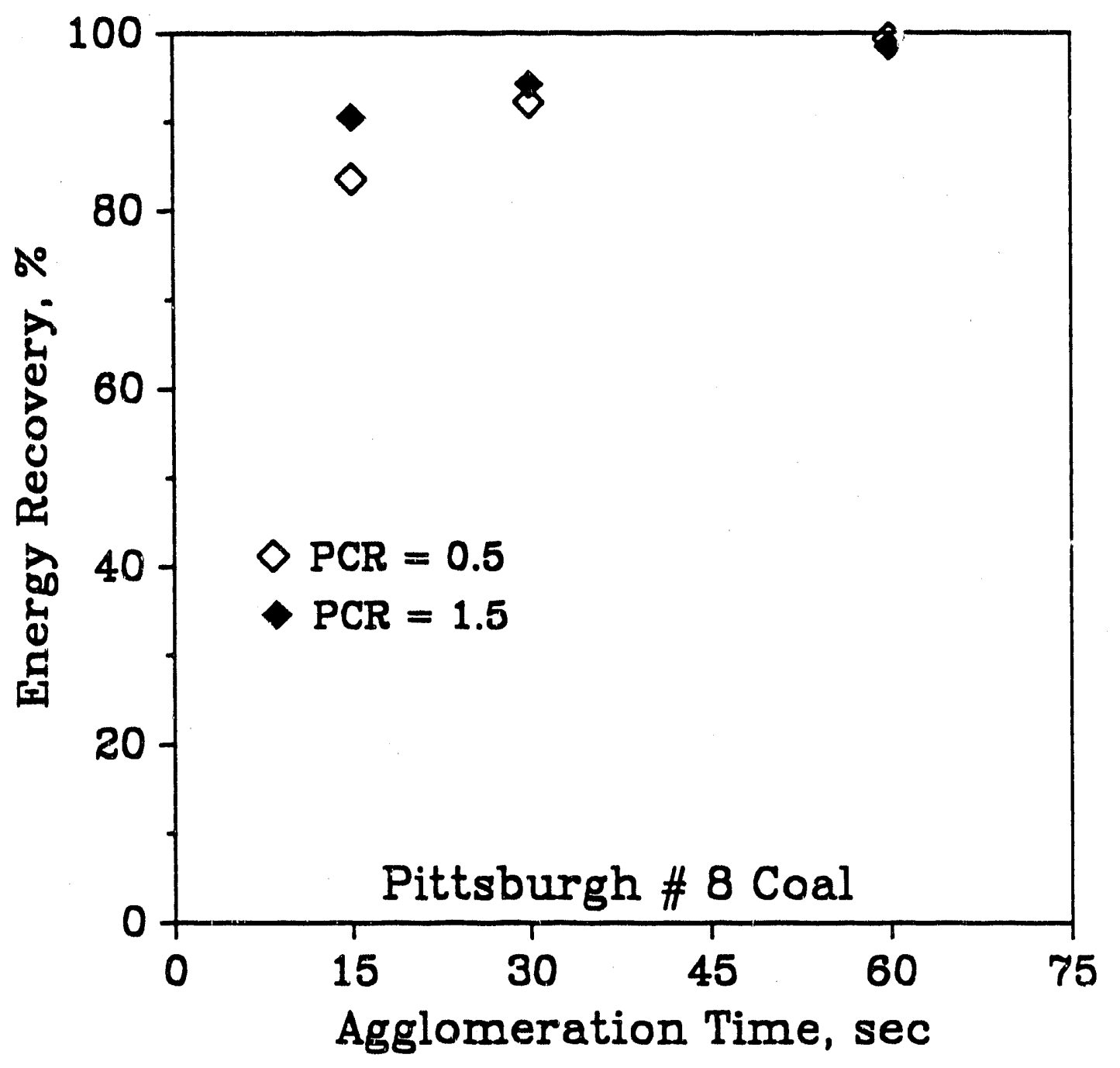

Figure 2.11.4-1 Effect of Pentane to Coal Ratio (PCR) on Energy Recovery for Pittsburgh \#8 Coal 


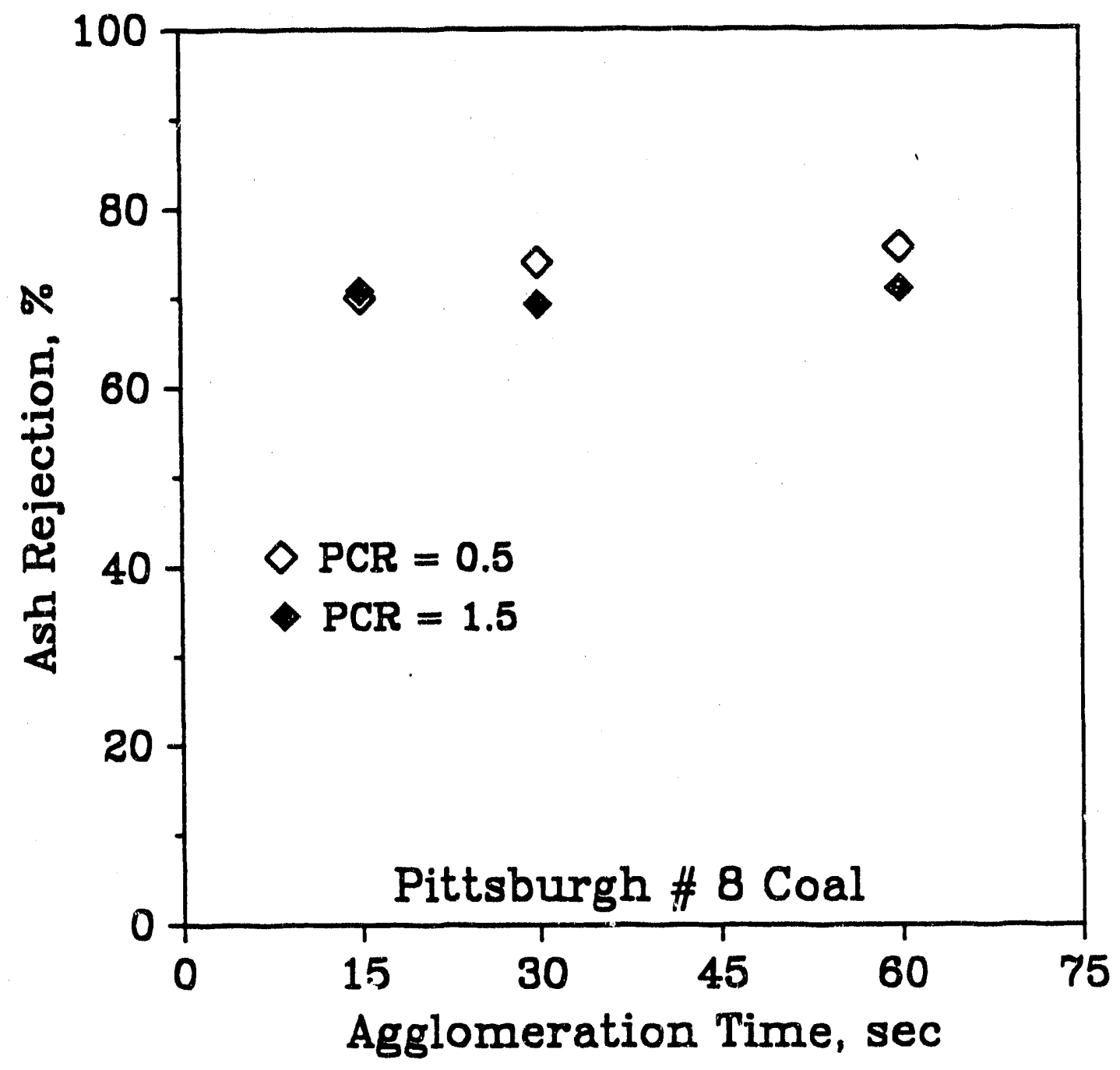

Figure 2.11.4-2 Effect of Pentane to Coal Ratio (PCR) on Ash Rejection for Pittsburgh \# 8 Coal 


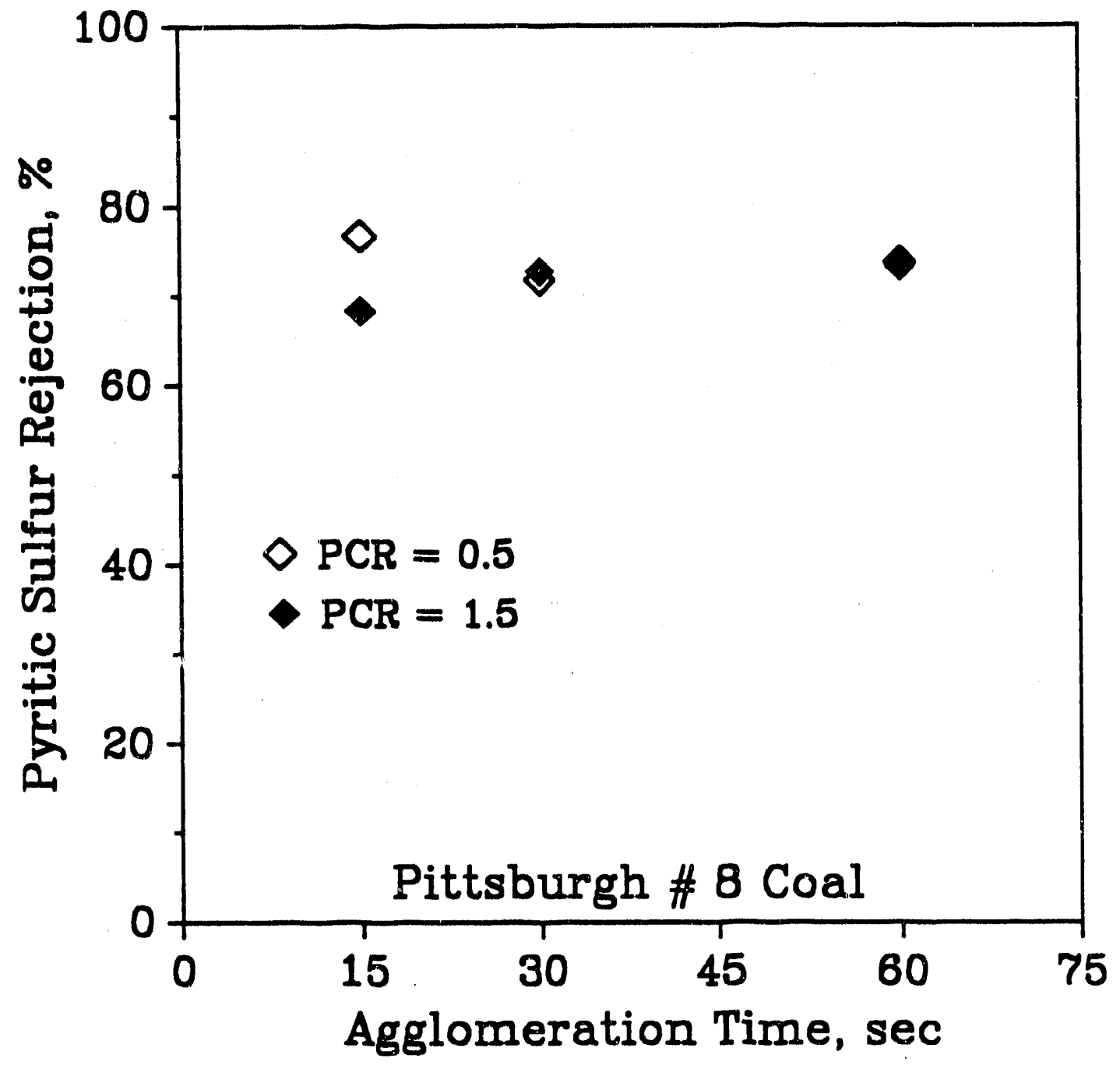

Figure 2.11.4-3 Effect of Pentane to Coal Ratio (PCR) on Pyritic Sulfur Rejection for Pittsburgh \# 8 Coal 
APPENDIX C: PYRITE SIZE DISTRIBUTION CALCULATION 


\section{APPENDIX C: PYRITE SIZE DISTRIBUTION CALCULATION}

The following discussion is a summary from Chapter 5 of "Quantitative Stereology" by E. E. Underwood ${ }^{(3)}$.

The plane intersection of a polydispersed system of spheres results in circular sections with a distribution of sizes, even in the case of spheres of uniform diameter. In the case of spheres with different diameters, $d_{j}, d_{j+1}, d_{j+2}$, etc., each size contributes circular sections of size $d_{i}\left(d_{i} \leq d_{j}\right)$. If the polydispersed system of spheres is divided into size intervals, the observed number of sections of diameter $d_{i},\left(N_{A}\right)_{i}$, is the sum of the contributions from intervals containing $s$ heres with diameter equal or larger than $d_{i}$. This statement can be expressed as

$$
\left(N_{A}\right)_{i}=\sum_{j=i}^{N}\left(N_{A}\right)_{i, j}
$$

where $\left(N_{A}\right)_{i, j}$ is the number per unit area of circles of size $d_{i}$ obtained from spheres of size $d_{j}$ and $N$ is the number of intervals. For each interval, the number of spheres of diameter $d_{j}$ per unit volume, $\left(N_{V}\right)_{j}$, can be written as

$$
\left(N_{V}\right)_{j}=\sum_{i}\left(N_{A}\right)_{i, j} / d_{j}
$$

In order to determine how many circular sections of each size come from spheres in each size interval, the probability of random planes intersecting a sphere must be obtained. If $P_{i, j}$ is the probability of a test plane intersecting a sphere of diameter $d_{j}$ to yield sections of diameter $d_{i}$, then

$$
P_{i, j}=\left(N_{A}\right)_{i, j} / \sum_{i}\left(I_{A}\right)_{i, j}
$$

Substituting equation 3 into 2 gives the general expression

$$
\left(N_{V}\right)_{j}=\frac{\left(N_{A}\right)_{i, j}}{P_{i, j} d_{j}}
$$

from whinh $\left(\mathrm{N}_{\mathrm{V}}\right)_{\mathrm{j}}$ may be determined. The calculation of $P_{\mathrm{i}, \mathrm{j}}$ is based on simple 
geometrical considerations. The probability of a plane randomly cutting a sphere within a slice of height $\mathrm{h}$, as shown in Figure $\mathrm{C}-1$, is equal to

$$
P_{\mathrm{i}, \mathrm{j}}=\frac{\mathrm{h}}{\mathrm{d}_{\mathrm{j}} / 2}=\frac{\mathrm{h}_{\mathrm{i}-1}-\mathrm{h}_{\mathrm{i}}}{\mathrm{d}_{\mathrm{j}} / 2}
$$

The probability may be expressed in terms of the diameters, as

$$
P_{\mathrm{i}, \mathrm{j}}=\left[\sqrt{\left(\mathrm{d}_{\mathrm{j}}\right)^{2}-\left(\mathrm{d}_{\mathrm{i}-1}\right)^{2}}-\sqrt{\left.\left(\mathrm{d}_{\mathrm{j}}\right)^{2}-\left(\mathrm{d}_{\mathrm{i}}\right)^{2}\right]} / \mathrm{d}_{\mathrm{j}}\right.
$$

It is immaterial whether a random plane intersects one sphere many times or if many identical spheres are intersected by one plane.

The values of $\left(\mathrm{N}_{\mathrm{V}}\right)_{j}$ can be obtained by first calculating $\left(\mathrm{N}_{\mathrm{V}}\right)_{\mathrm{N}}$ from the above equations for $\mathrm{i}=\mathrm{j}=\mathrm{N}$, as

$$
\left(\mathrm{N}_{\mathrm{V}}\right)_{\mathrm{N}}=\frac{\left(\mathrm{N}_{\mathrm{A}}\right)_{\mathrm{N}, \mathrm{N}}}{P_{\mathrm{N}, \mathrm{N}} \mathrm{d}_{\mathrm{N}}}=\frac{\left(\mathrm{N}_{\mathrm{A}}\right)_{\mathrm{N}}}{P_{\mathrm{N}, \mathrm{N}} \mathrm{d}_{\mathrm{N}}}=\frac{\left(\mathrm{N}_{\mathrm{A}}\right)_{\mathrm{N}}}{\sqrt{\left(\mathrm{d}_{\mathrm{N}}\right)^{2}-\left(\mathrm{d}_{\mathrm{N}-1}\right)^{2}}}
$$

The value of $\left(\mathrm{N}_{\mathrm{V}}\right)_{\mathbf{N}}$ is then used to determine $\left(\mathrm{N}_{\mathbf{A}}\right)_{\mathrm{N}-1, \mathrm{~N}-1}$ using equation 1 for $\mathrm{i}=\mathrm{N}-1$, as

$$
\left(\mathrm{N}_{\mathbf{A}}\right)_{\mathrm{ii}}=\left(\mathrm{N}_{\mathrm{A}}\right)_{\mathrm{i}}-\sum_{\mathrm{j}=\mathrm{i}+1}^{\mathrm{N}}\left(\mathrm{N}_{\mathrm{v}}\right)_{\mathrm{j}} P_{\mathrm{i}, \mathrm{j}} \mathrm{d}_{\mathrm{j}}
$$

$\left(\mathrm{N}_{\mathrm{V}}\right)_{\mathrm{N}-1}$ is then determined using equation 4 for $\mathrm{i}=\mathrm{j}=\mathrm{N}-1$, as

$$
\left(\mathrm{N}_{\mathrm{V} \cdot \mathrm{i}}\right)=\frac{\left(\mathrm{N}_{\mathrm{A}}\right)_{\mathrm{ii}}}{P_{\mathrm{ii}} \mathrm{d}_{\mathrm{i}}}
$$

The same procedure is continued down to the smallest particle size. It can be seen that each subtracted term depends on previously calculated values and that the number of smaller particles may be inaccurate because of aciumulated errors.

The frequency distribution can then be converted into voiume distribution using

$$
V_{i}=\frac{\left(N_{V}\right)_{i}\left(d_{i}\right)^{3}}{\sum\left(N_{V}\right)_{i}\left(d_{i}\right)^{3}}
$$

where $V_{i}$ is the volume fraction of particles in the diameter interval $i$. 


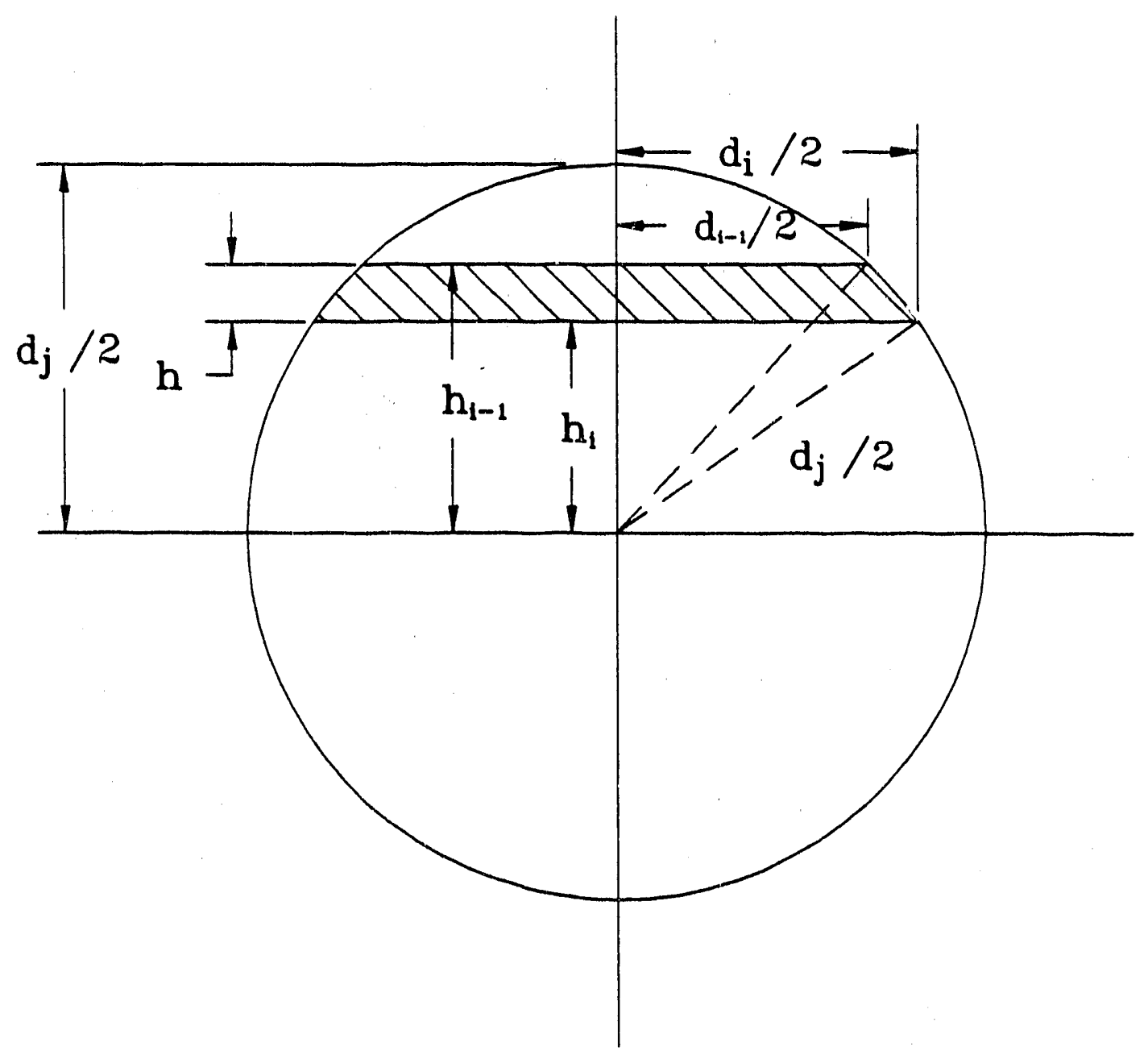

Figure C-1 Geometry Involved in the Incersection of a Sphere by a Plane Within the Slice $h$ 
A computer program based on the above equations was written in BASIC to determine the three-dimensional frequency distribution of sizes for pyrite. The program calculates the volume distributions for locked, semi-locked, and free pyrite particles. A listing of the program is presented nex.t.

\section{Pyrite Size Distribution Program}

- Transformation fron Area Number Distribution to Volume Distribution

- Nomenclature

,

- d diameter

I n number of diameters

I na 2-D number distribution

I nv 3-D number distribution

'pyrtypes pyrite type

i v volume distribution

,

$\operatorname{DIM} d(50,3), \operatorname{na}(50,3), n v(50,3), n(3)$

DIM V(50, 3), pyrtypes(3)

pyrtypes(1) = "Locked"

pyrtypes(2) = "Semi-Locked"

pyrtypes(3) = "Free"

,

FOR $k=1$ TO 3

$d(0, k)=0$

NEXT

CLS : LOCATE 3, 10

INPUT "Enter datn file name > ", ifns

OPEN ifnS FOR INPUT AS \#1

,

FOR $k=1$ TO 3

INPUT $* 1, n(k)$

$n=n(k)$

FOR $i=1$ TO $n$

INPUT \#1, d(i, $k)$, na(i,k)

NEXT

$n v(n, k)=n a(n, k) / \operatorname{sQR}(d(n, k) * d(n, k)-d(n-1, k) * d(n-1, k))$

FOR $i=n-1$ TO 1 STEP -1

$n+(i, k)=n a(i, k)$

FOR $j=n$ TO $i+1$ STEP -1

$n$ term $=n v(j, k) *(\operatorname{sar}(d(j, k) * d(j, k)-d(i-1, k) * d(i-1, k))-\operatorname{sar}(d(j, k) * d(j, k) \cdot$ $d(i, k) * d(i, k i))$

$n v(i, k)=n v(i, k)$ - nterm 


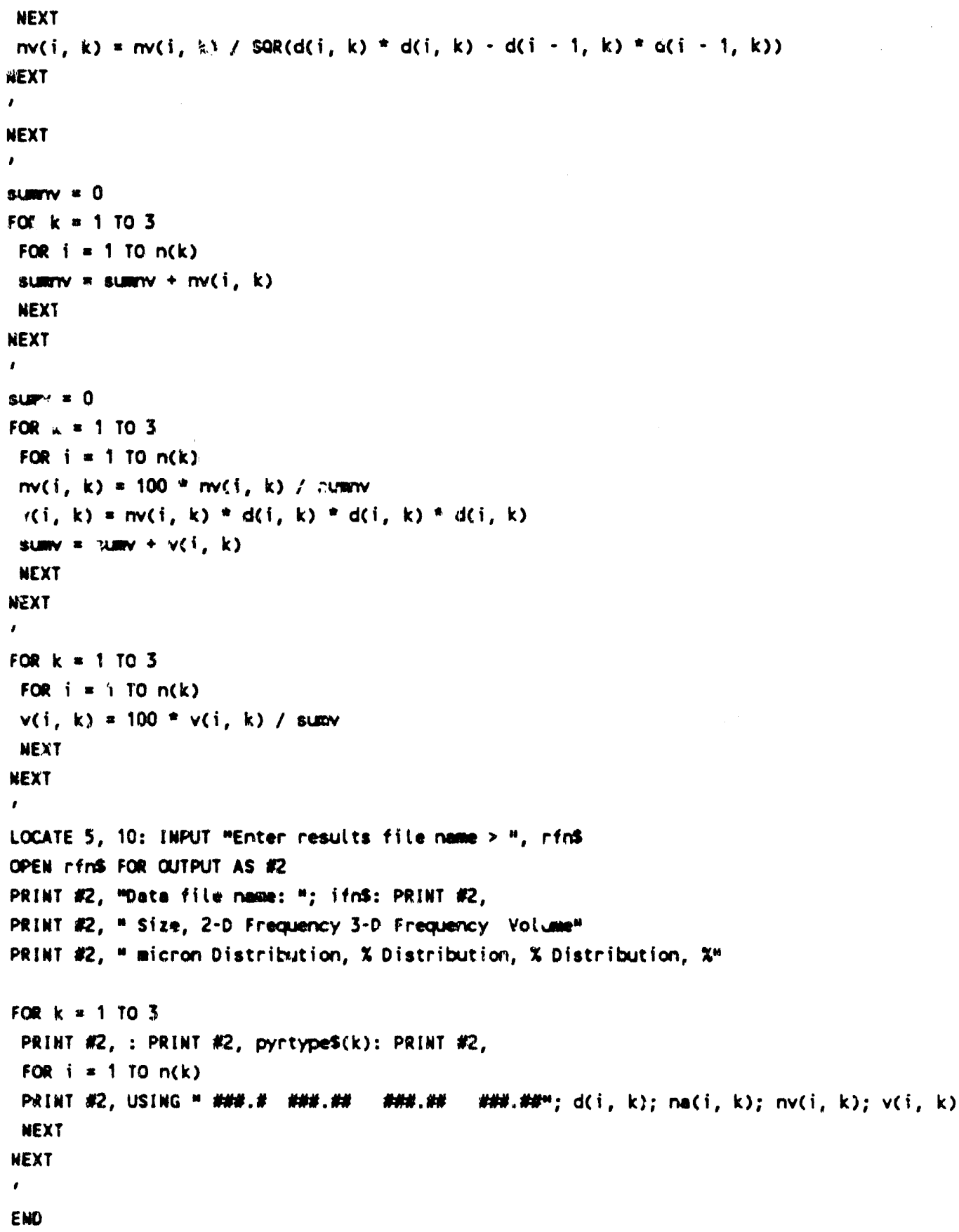


APPENDIX D: AGGLOMERAT TIN TEST RESULTS USING LIGHT HYDROCARBONS DURING GRINDING 


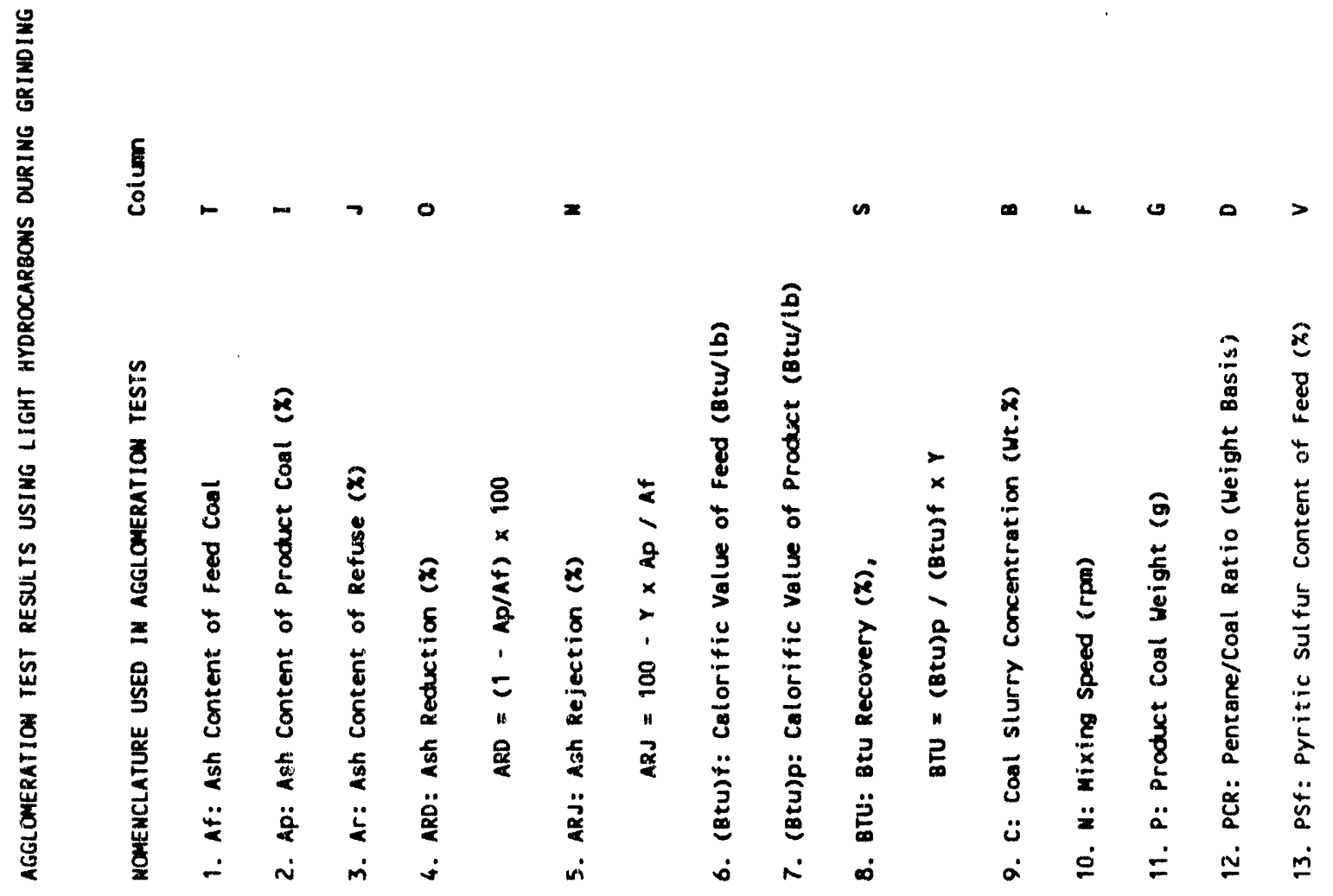




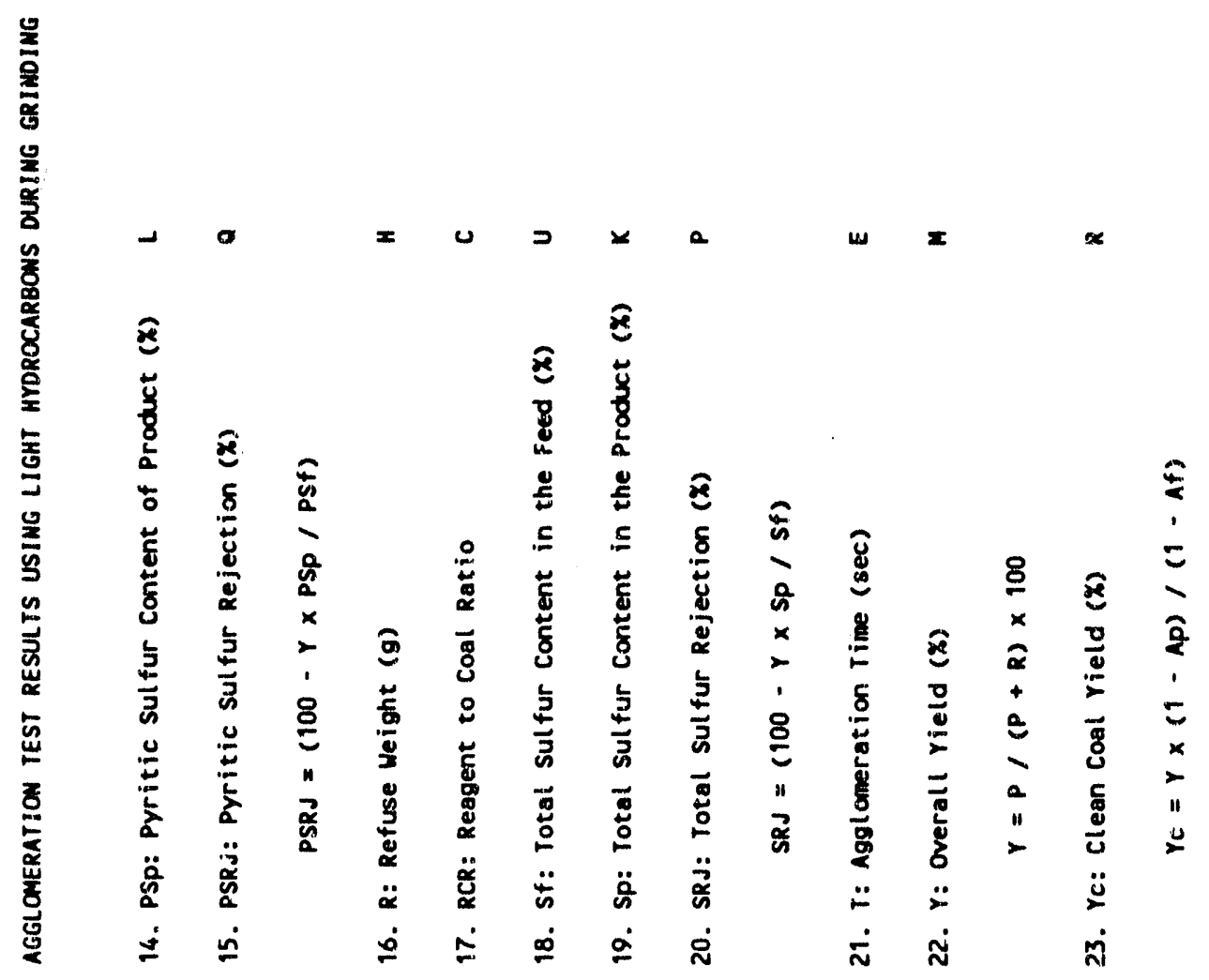




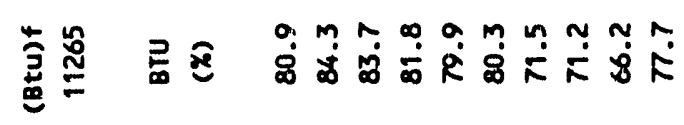

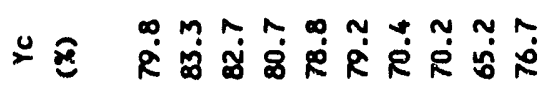

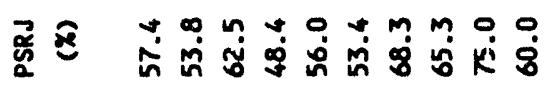

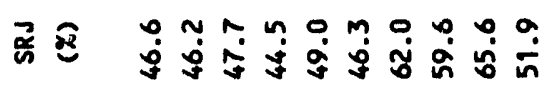

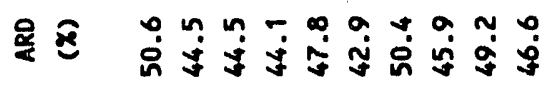

द⿱乛龰己

- 8 в

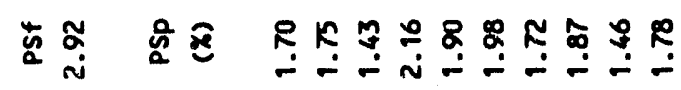

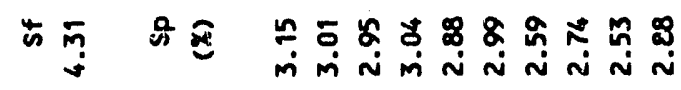

₹8 $80 \%$

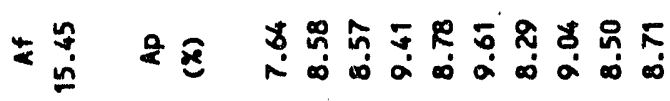

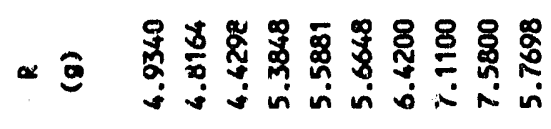

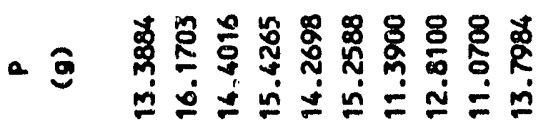

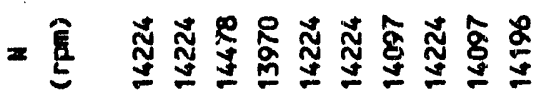

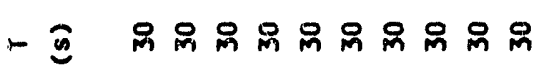

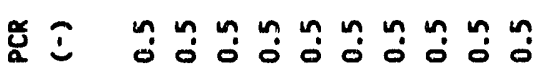

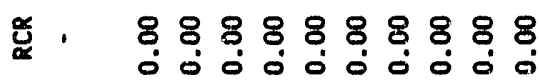

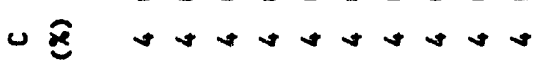

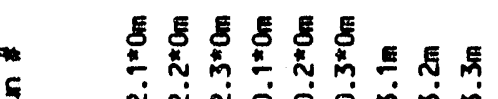

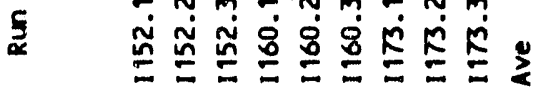




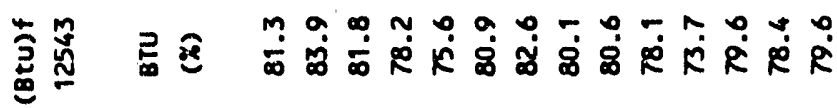

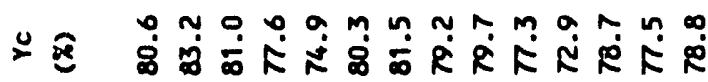

2)

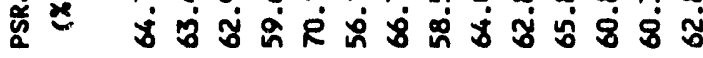

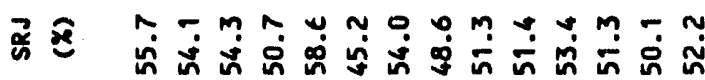

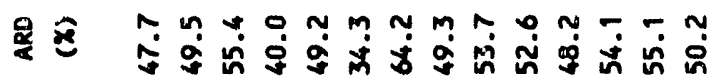

₹

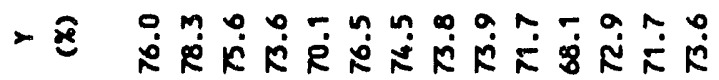

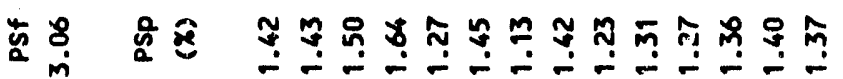

万人

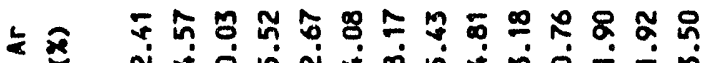

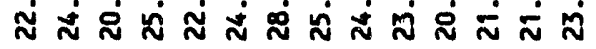

₹華 2 \&

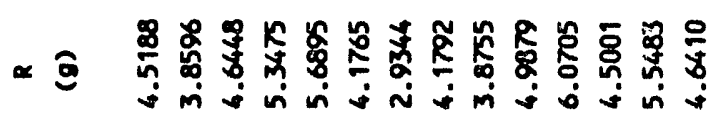

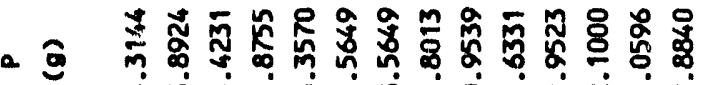

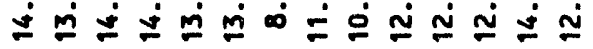

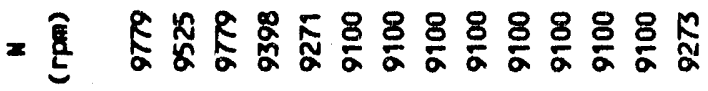

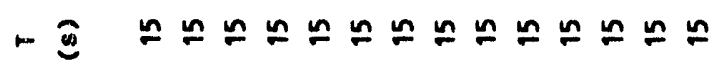

¿

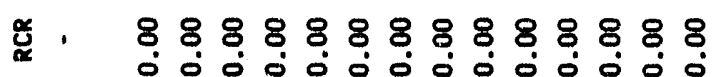

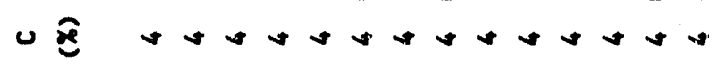

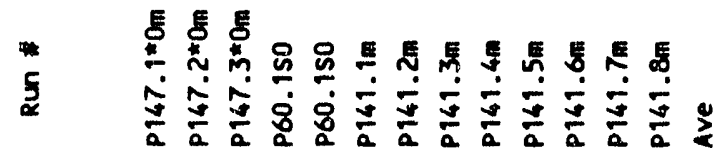




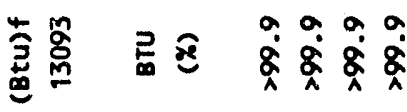

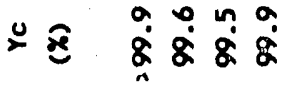

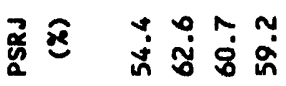

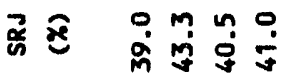

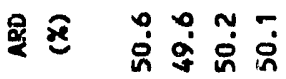

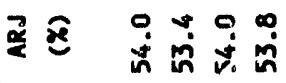

- बำ

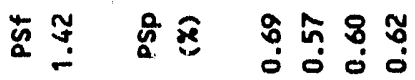

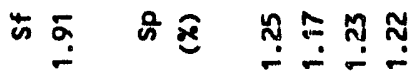

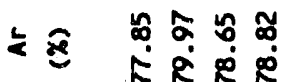

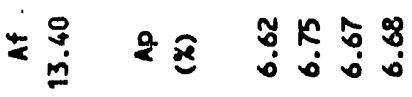

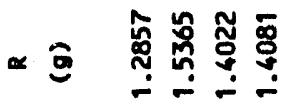

a ○

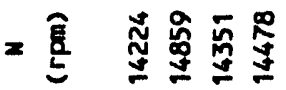

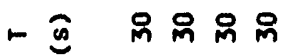

ะ气

\% 8880

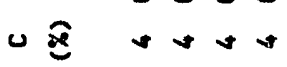




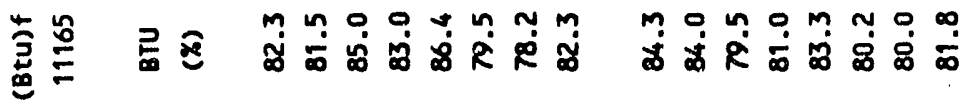

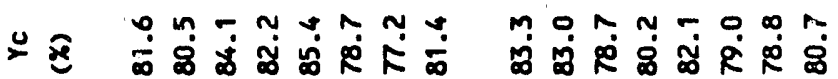
롤 zo 8

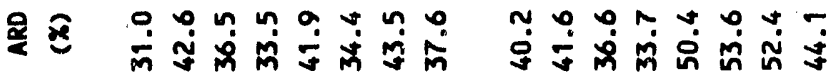

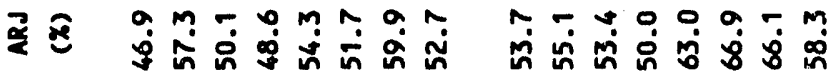

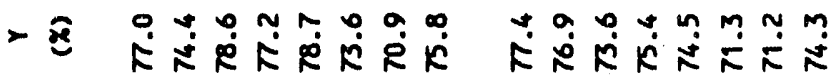

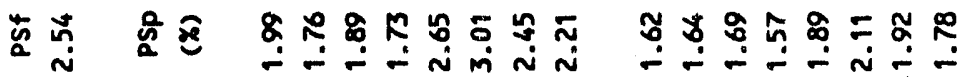

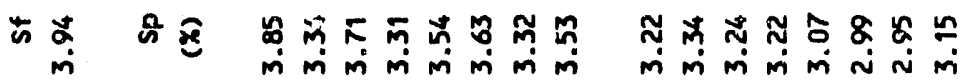

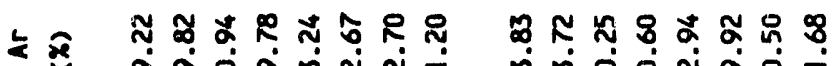

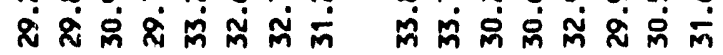

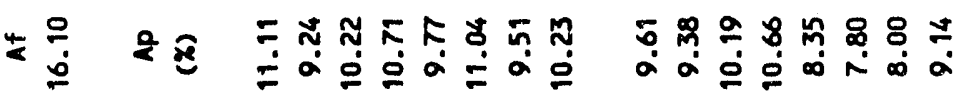

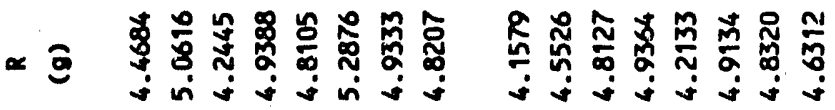

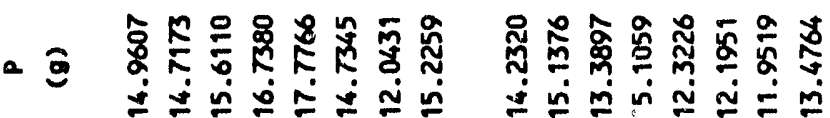

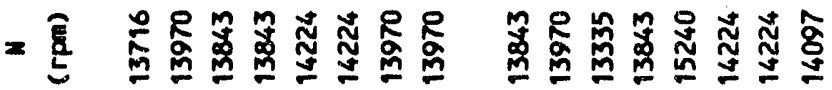

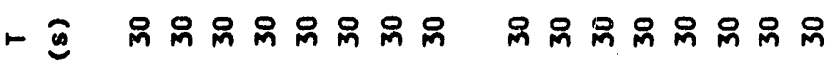

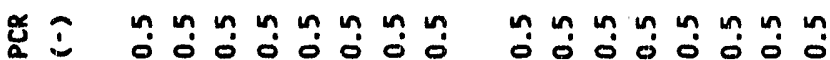

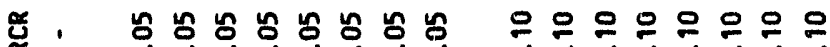

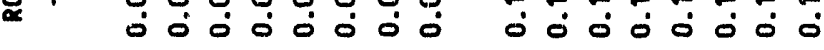

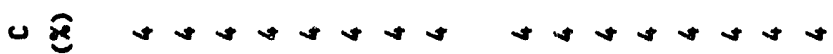

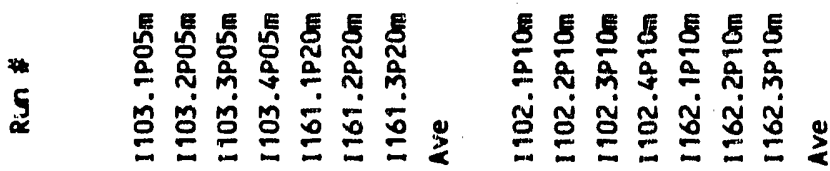




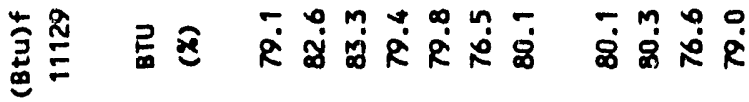

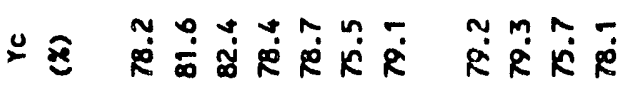

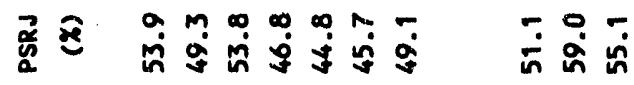

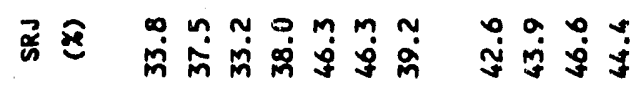

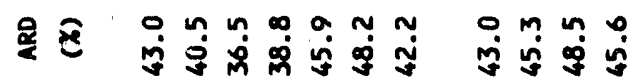

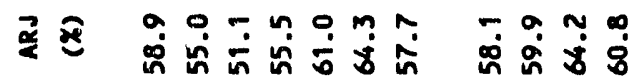

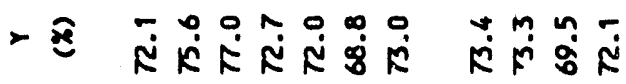

50

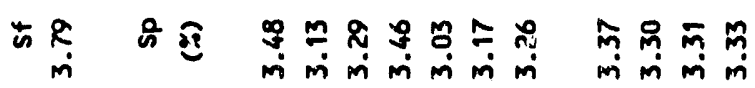

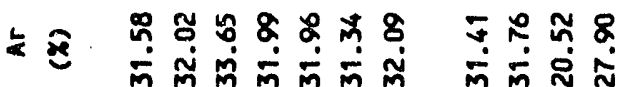

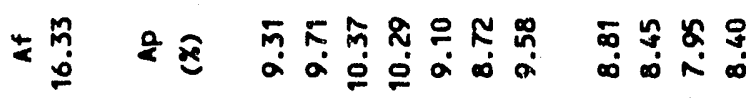

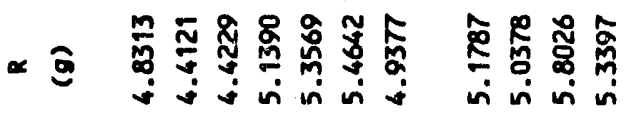

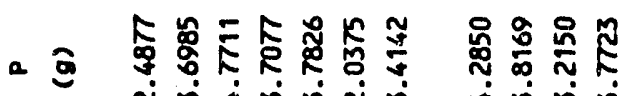

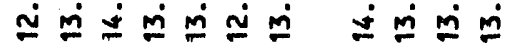

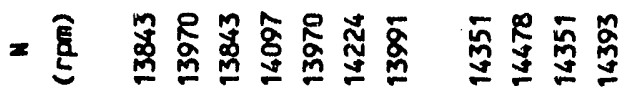

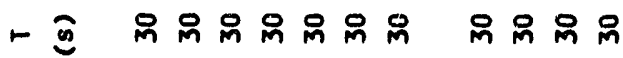

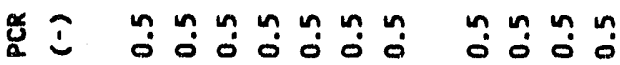

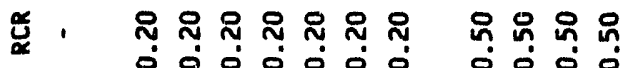

U 3

ร 


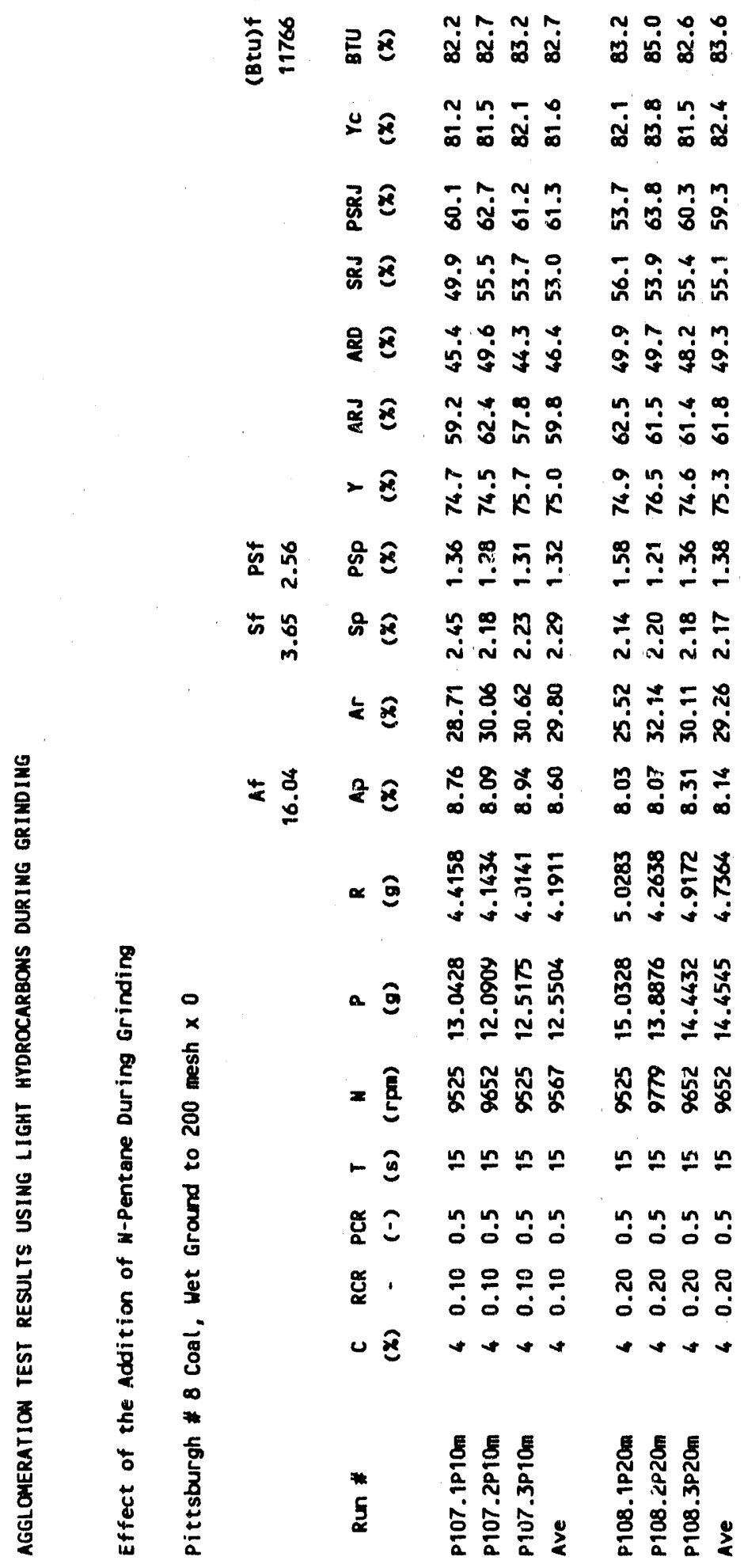




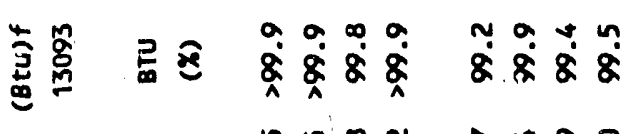

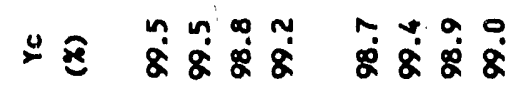

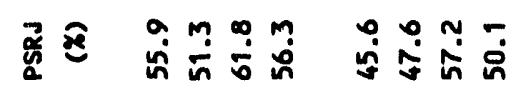

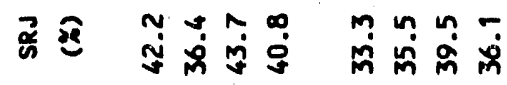

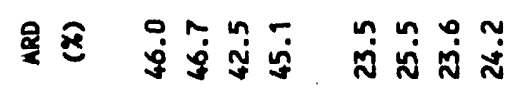

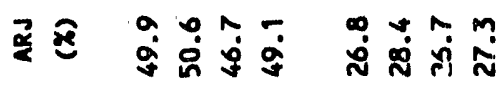

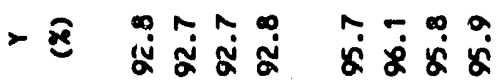

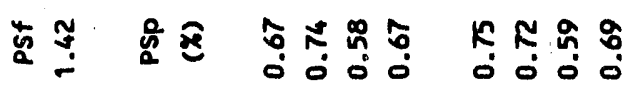

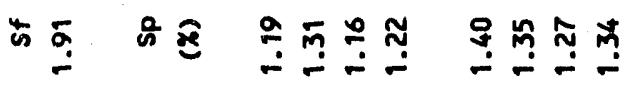

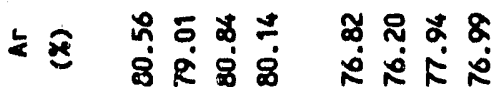

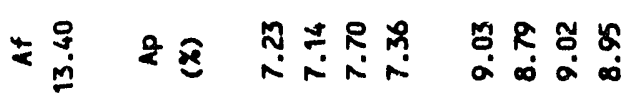

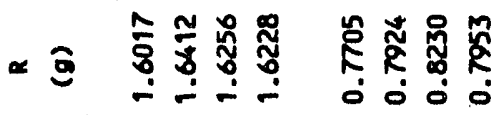

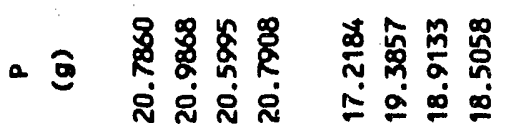

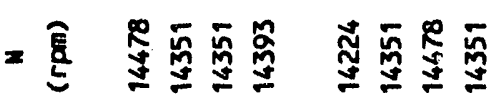

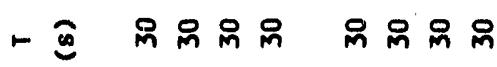

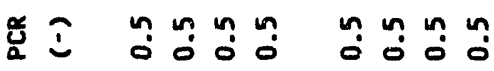

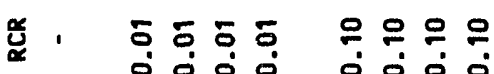

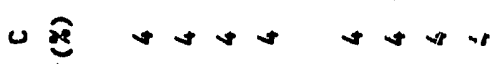

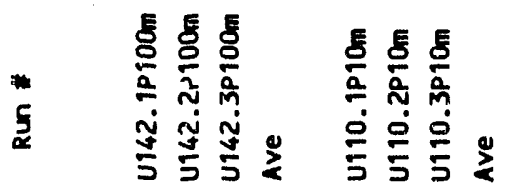




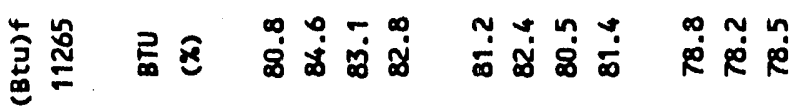

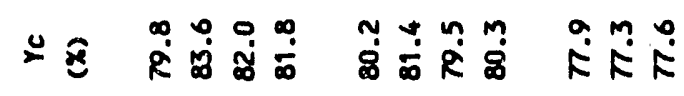

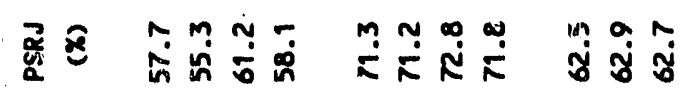

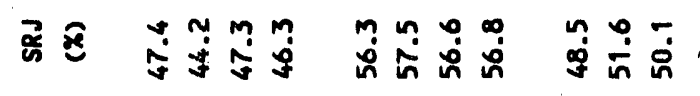
ำ 로

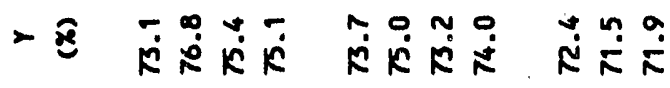
50ำ

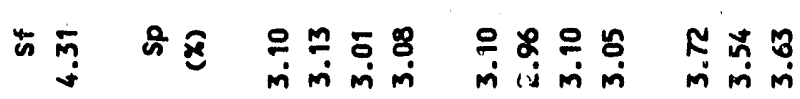
₹ह

$=2$ ₹

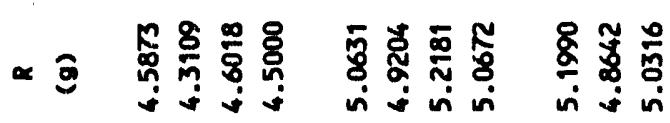

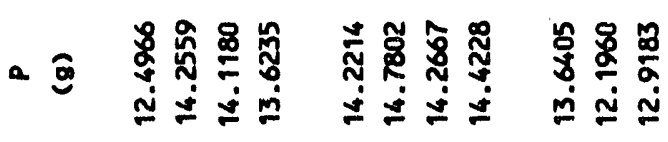

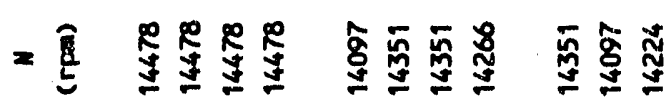

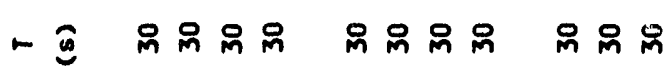

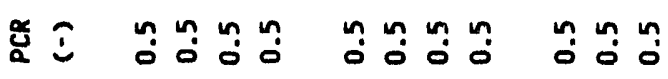

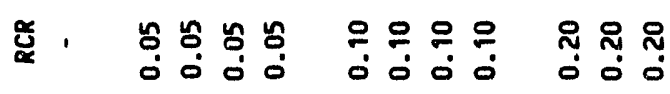

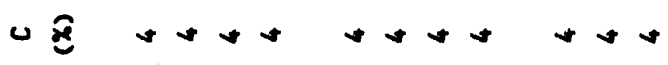
5 


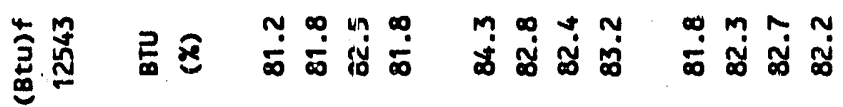
ㅇำ

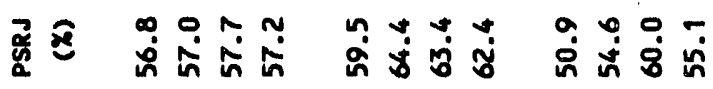

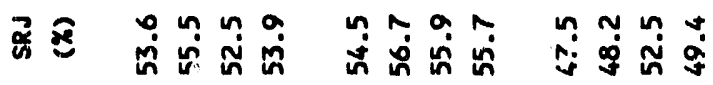
จุ

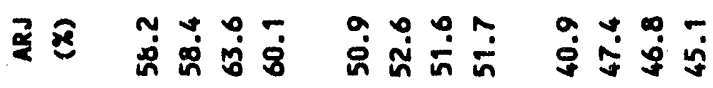

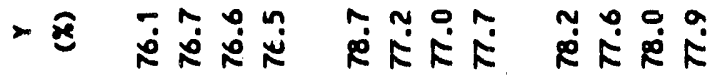

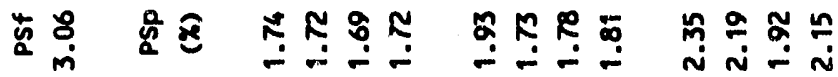
ち

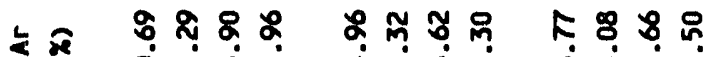

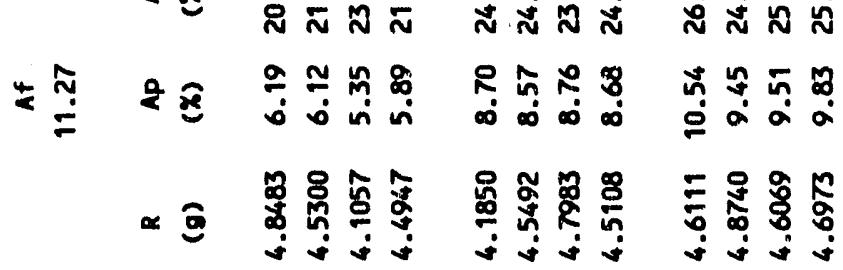

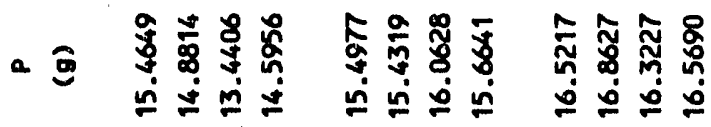

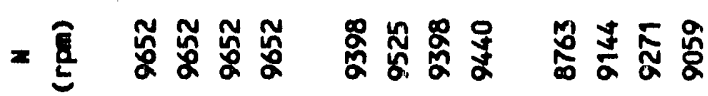

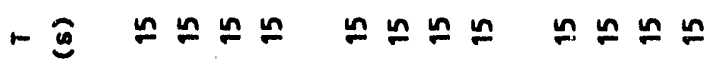

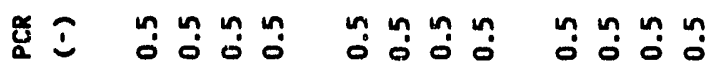
ช้

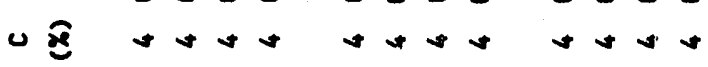

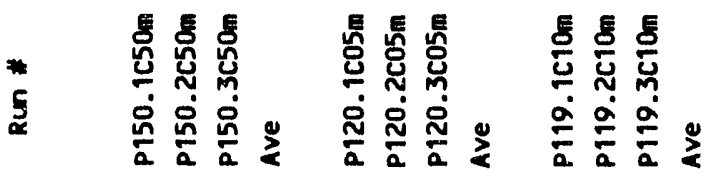




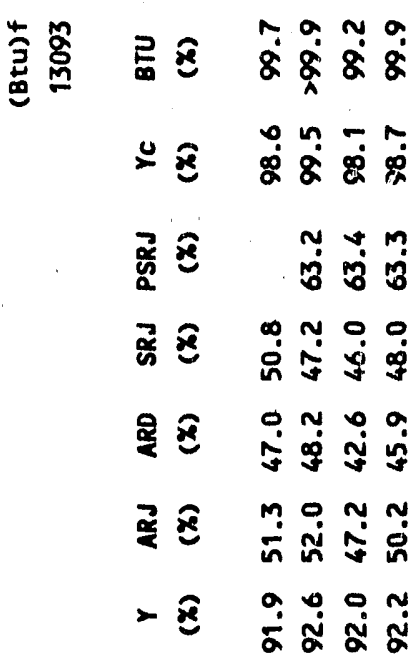

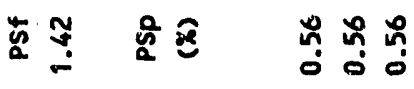

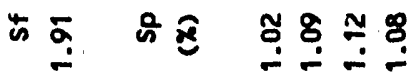

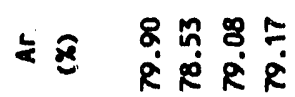

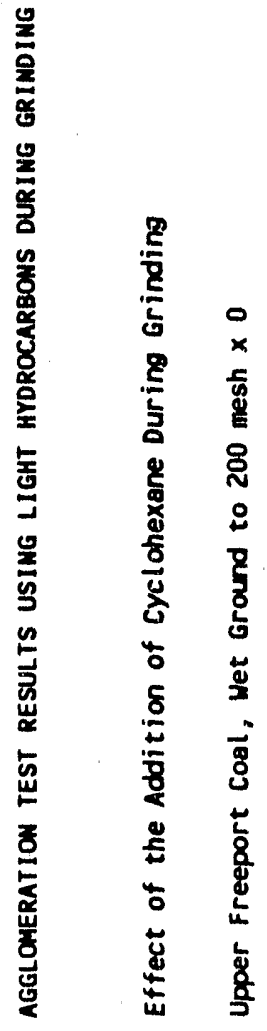

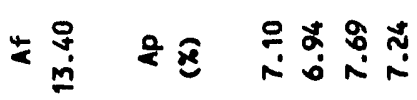

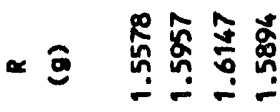

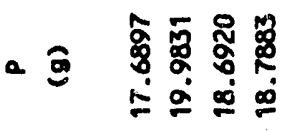

-

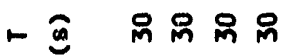

ะ ป

菑

पर्ष w

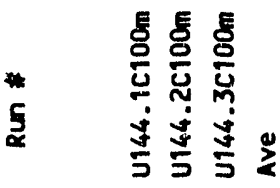




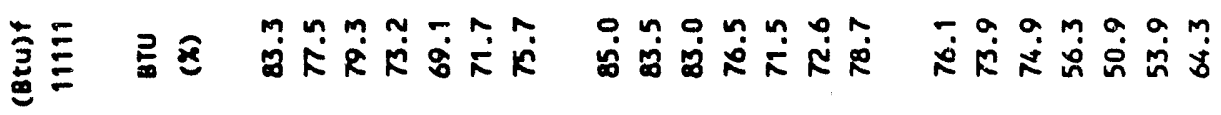
ะ

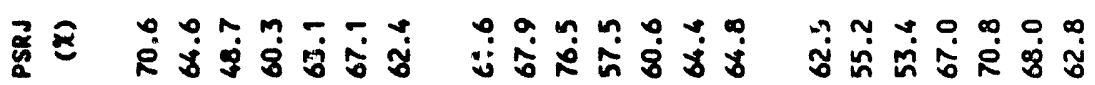

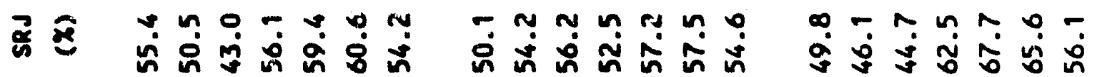

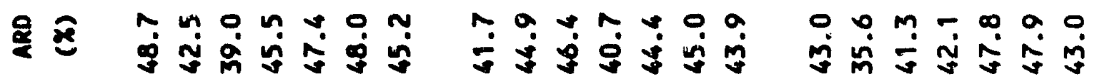

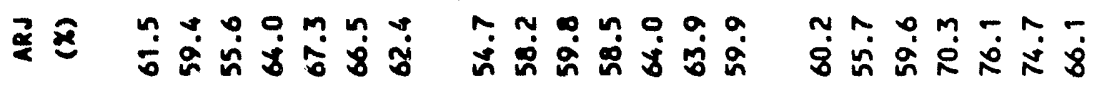

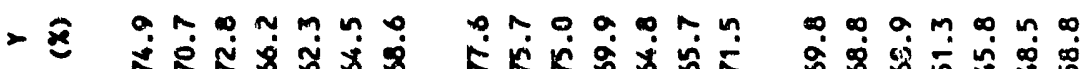

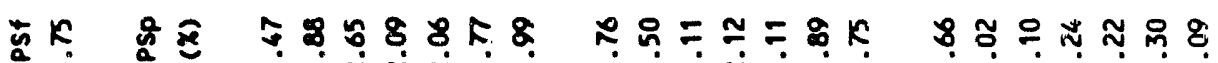

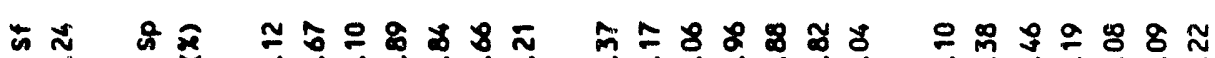

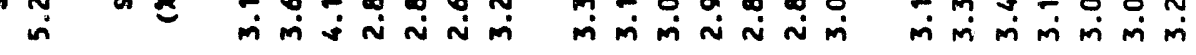

ระ

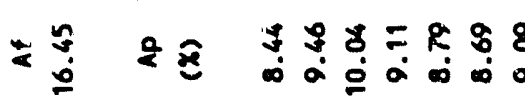

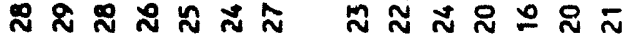

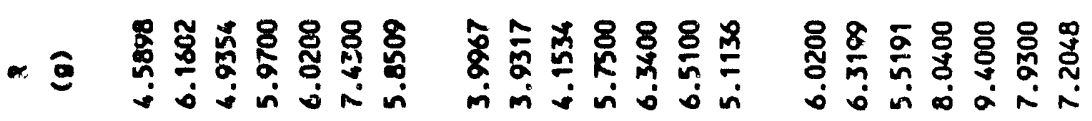

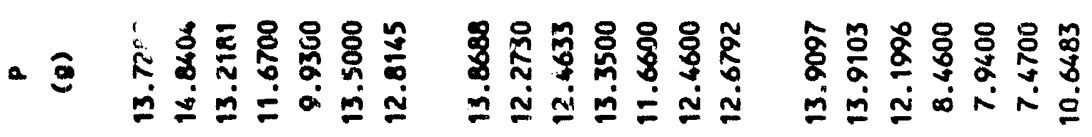

-

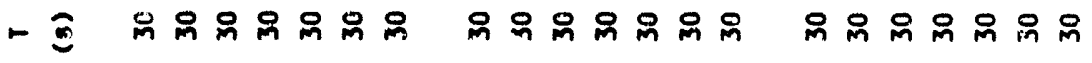

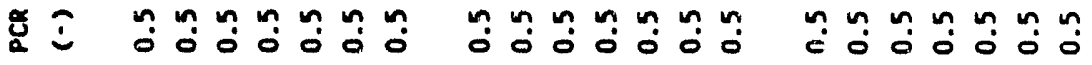

ㄴ.

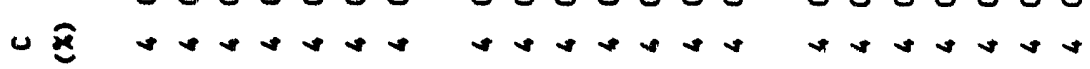

; 


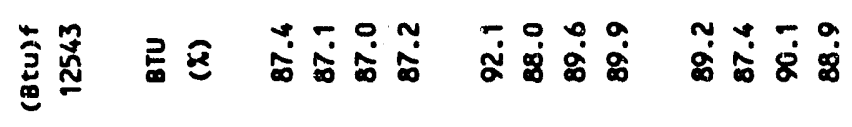
ㅃำ

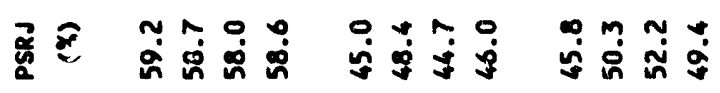

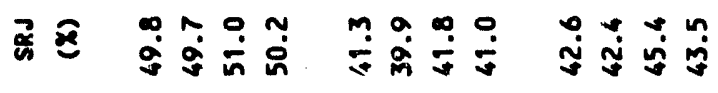

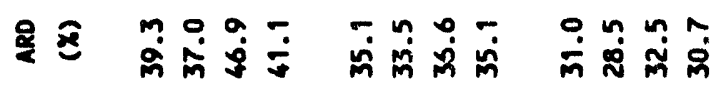
로

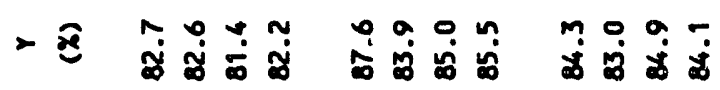

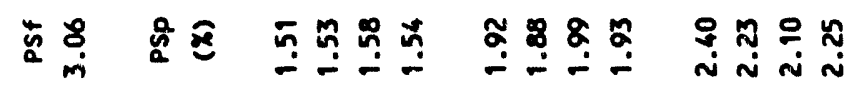
的总

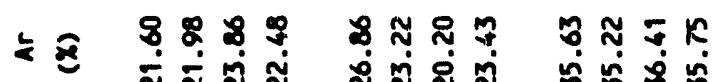

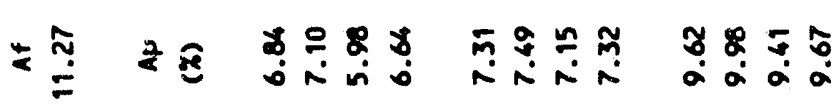

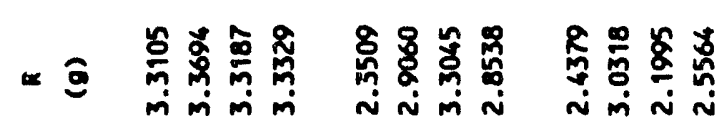

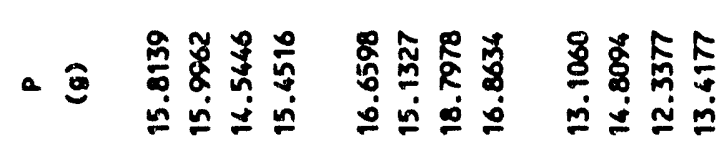

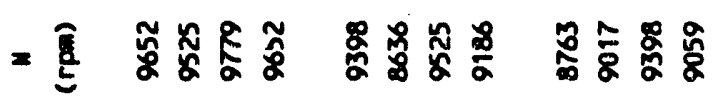

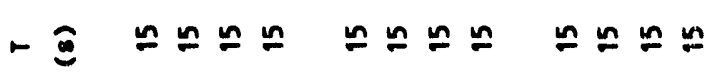

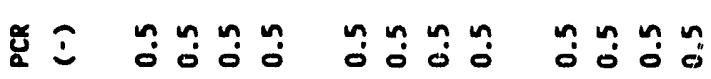

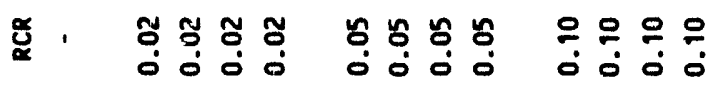
0 制

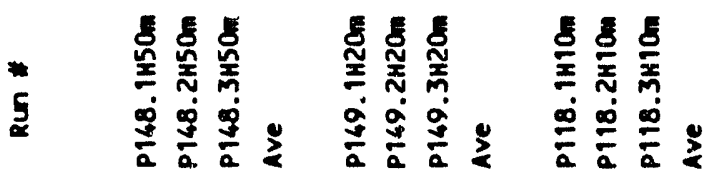




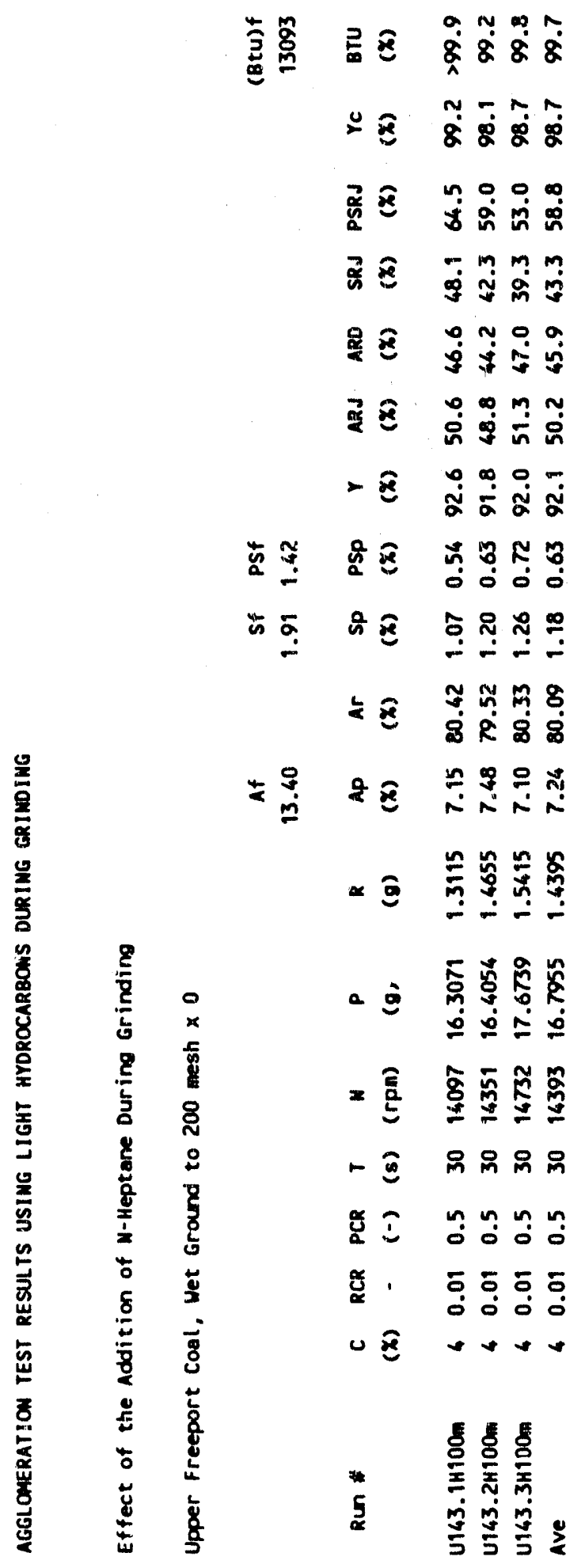


APPENDIX E: TEST RESULTS FOR THE OPTIMIZATION OF THE AGGLOMERATION PROCESS 


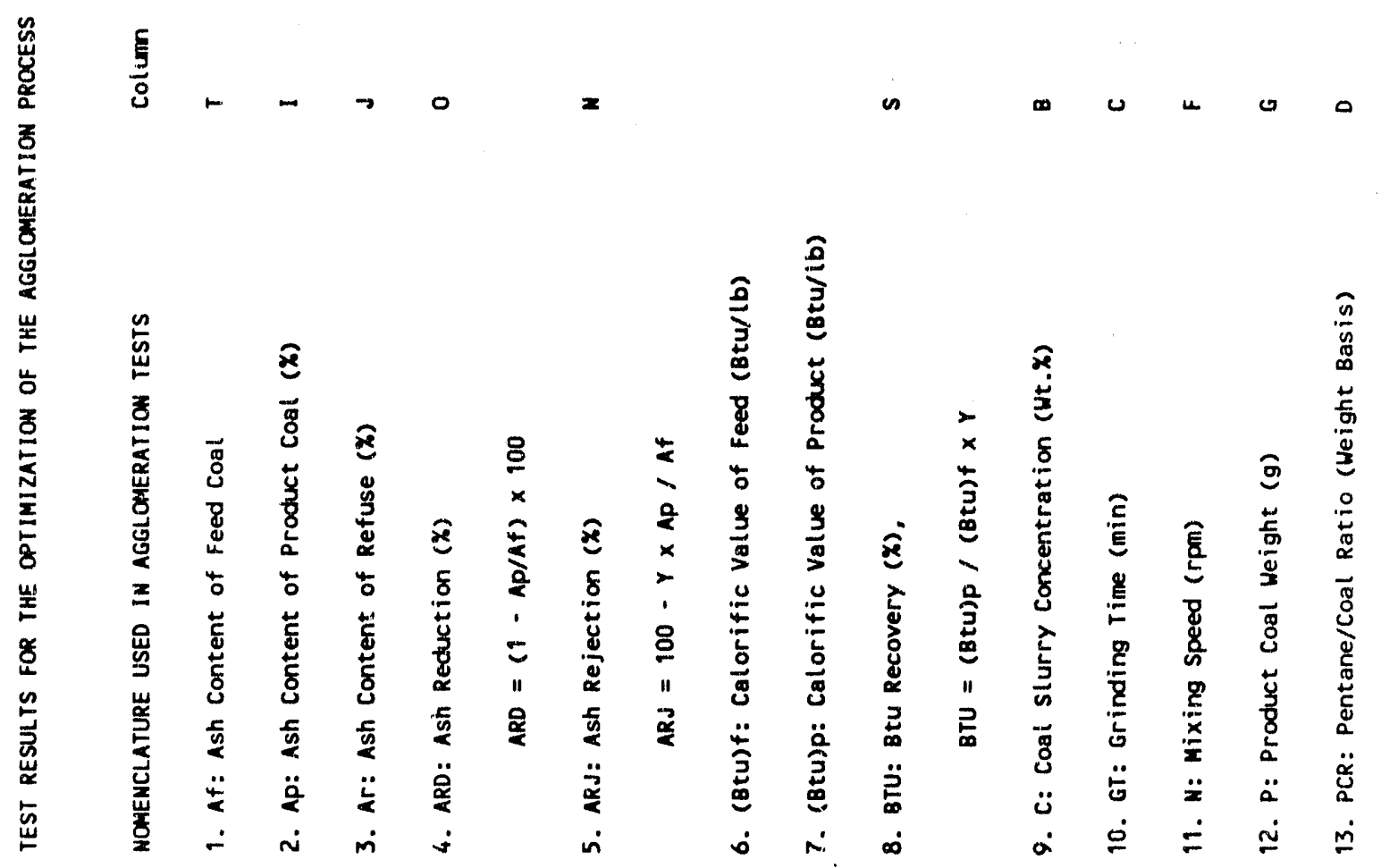




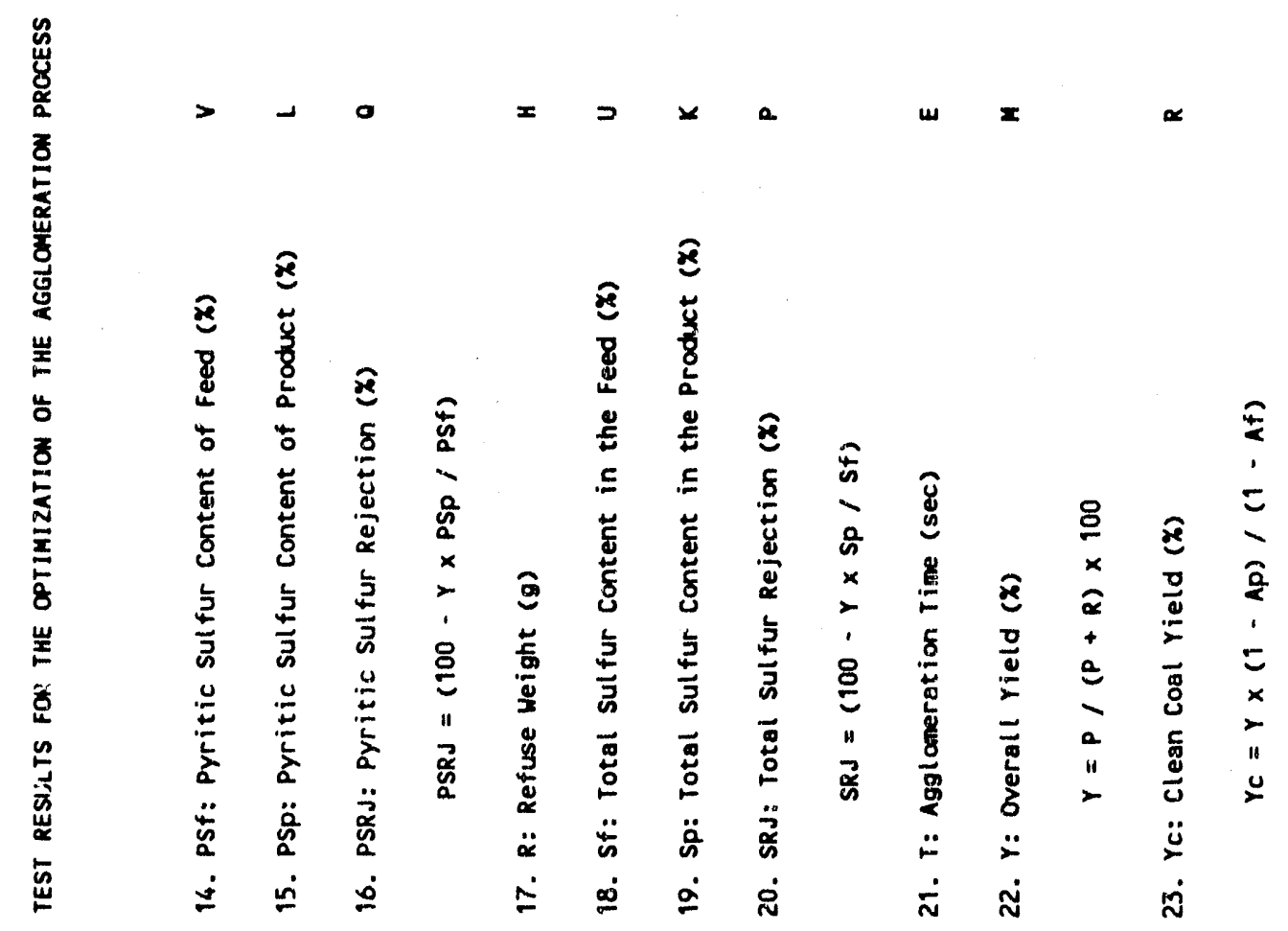




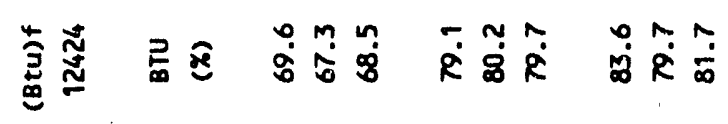

$=$ ะ

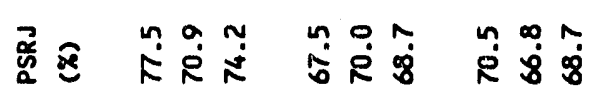

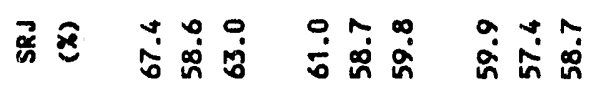

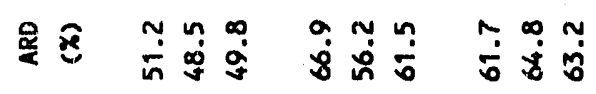

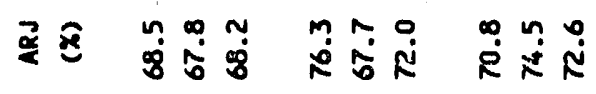

-

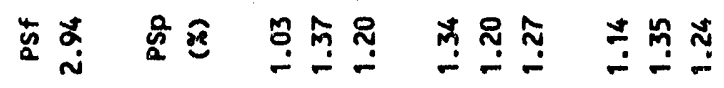

นด

₹

₹

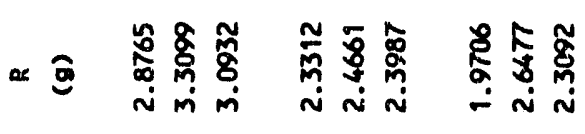

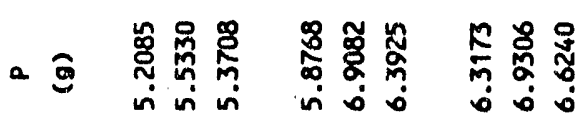

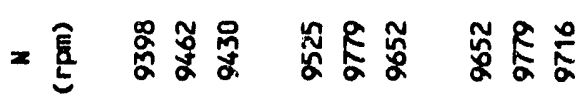

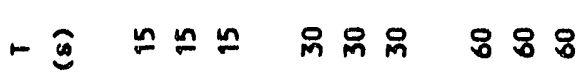

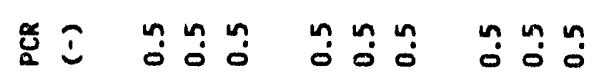

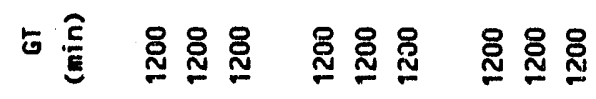

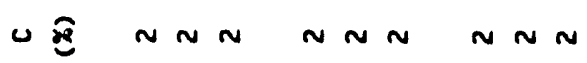

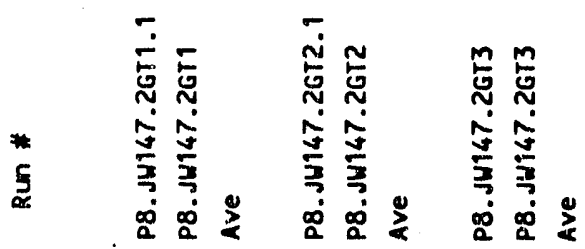




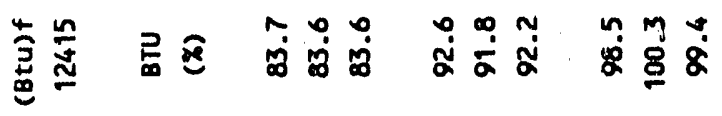

ะ

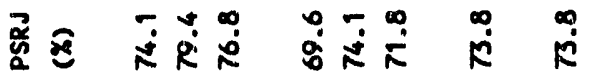

至

จุช

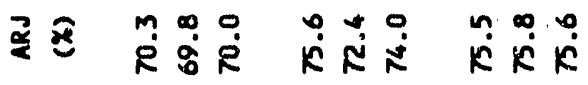

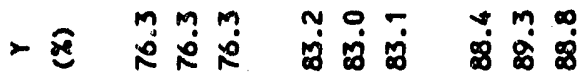

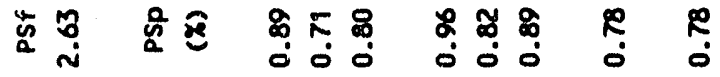

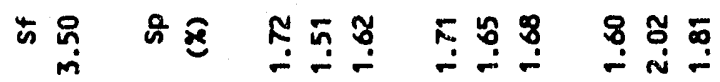

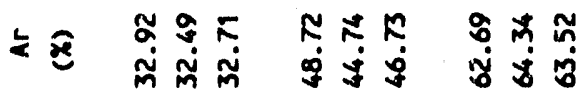

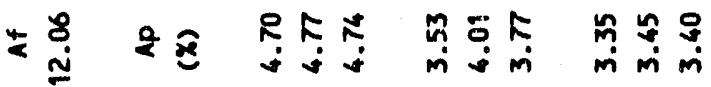

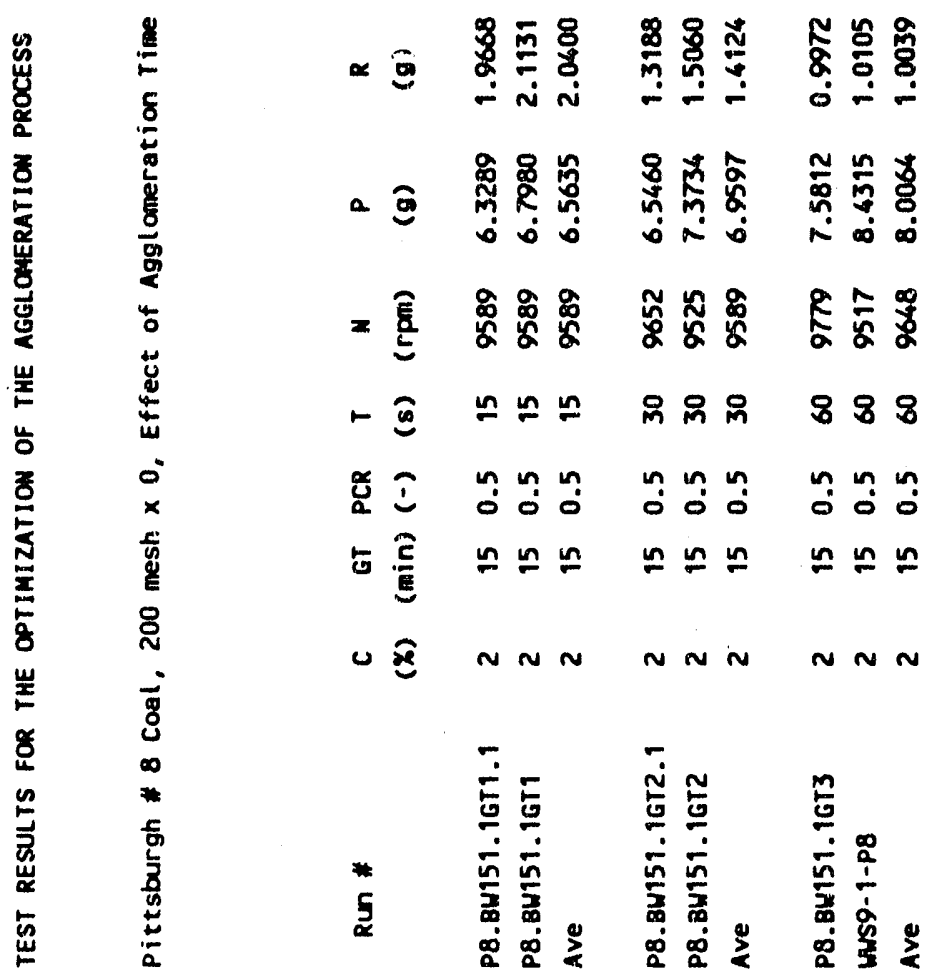




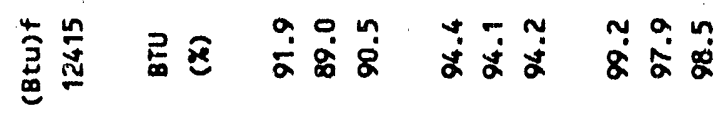
ะ

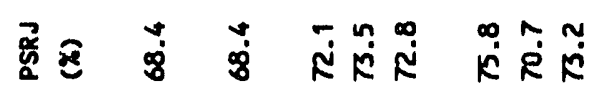

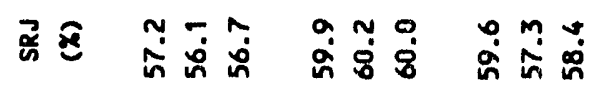

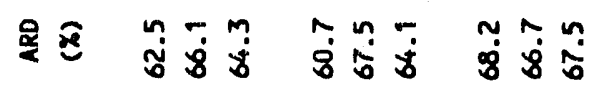

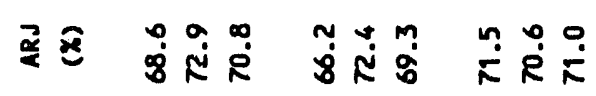

-

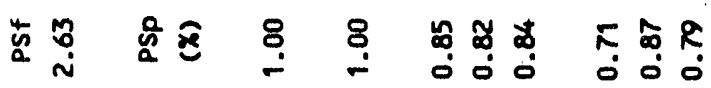

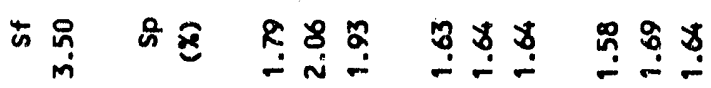

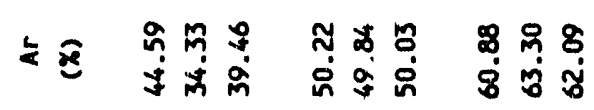

ะ 2 2

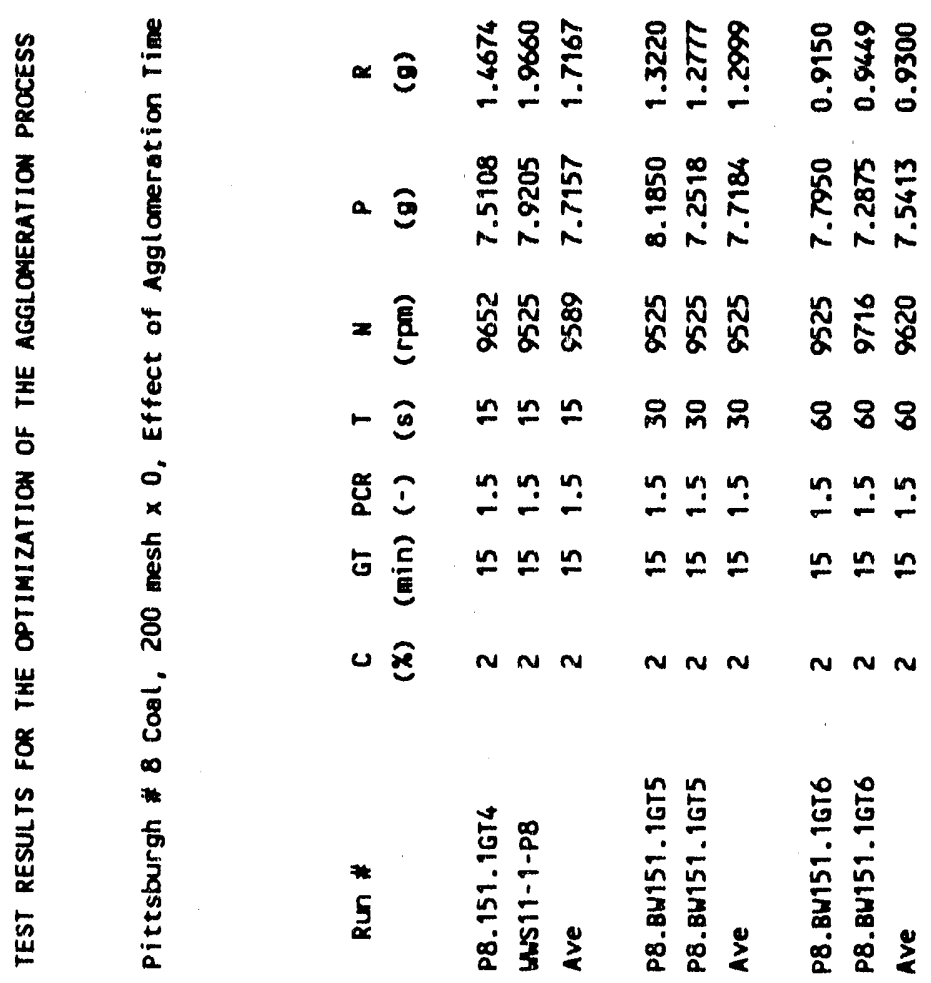




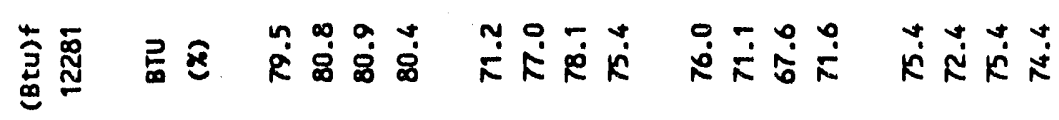
உ

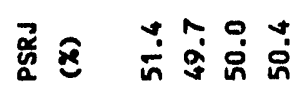

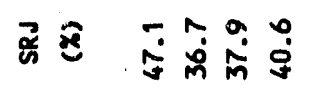
จำ

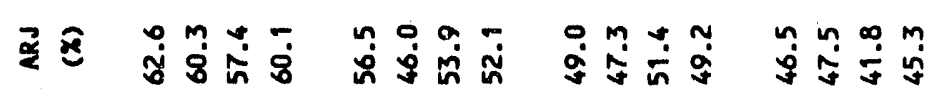
一 -

5

万ั

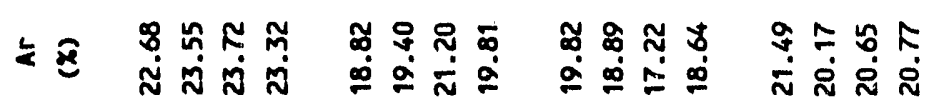

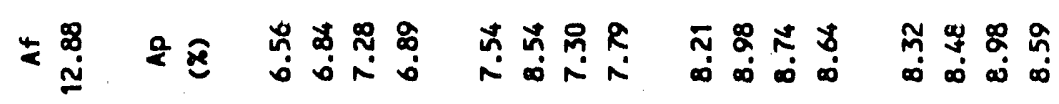

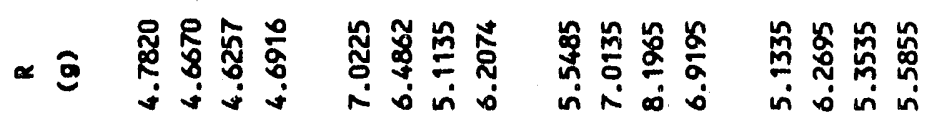

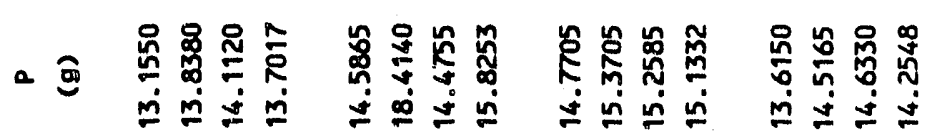

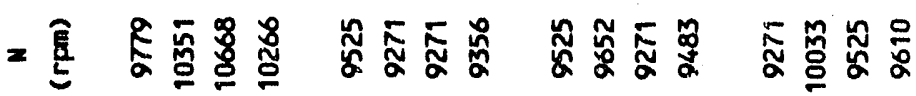

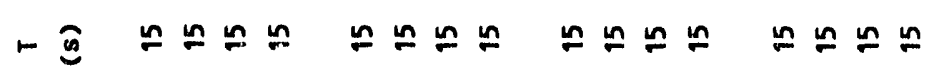

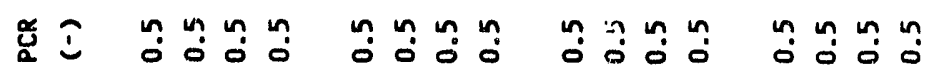

ธ

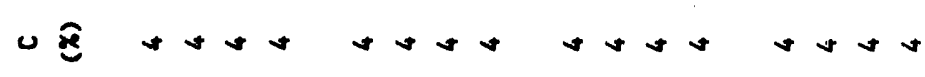

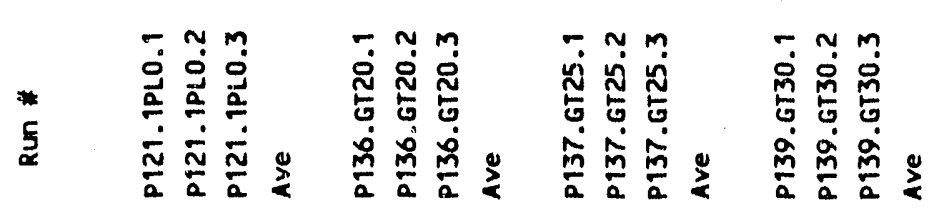




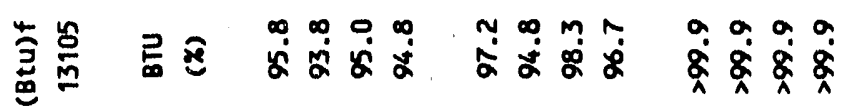

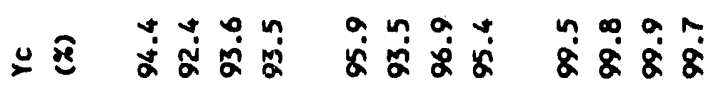

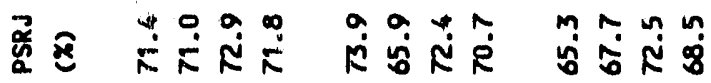

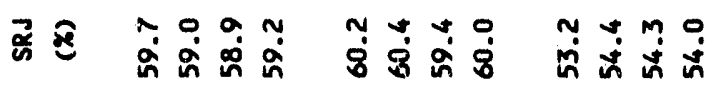

จำ

至区

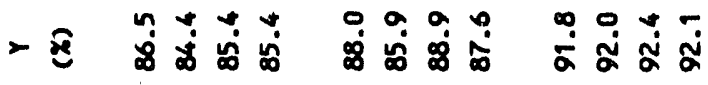

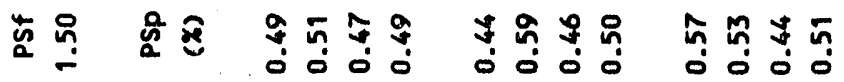

ち

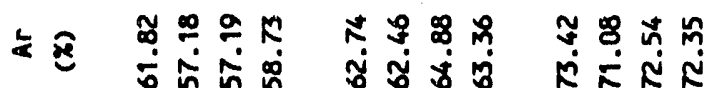

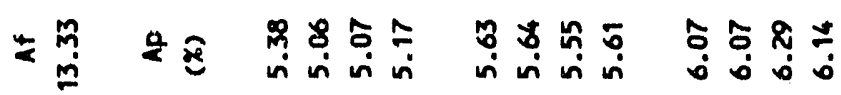

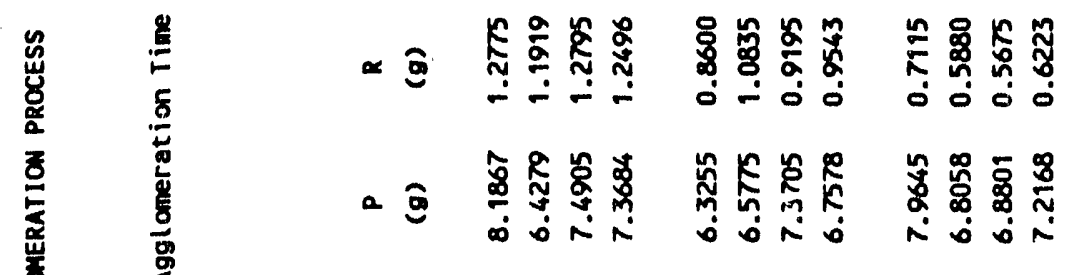

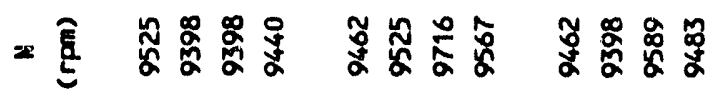

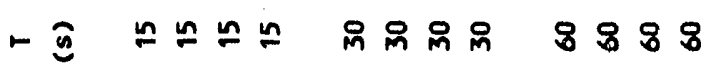

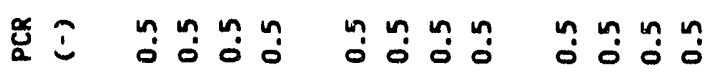

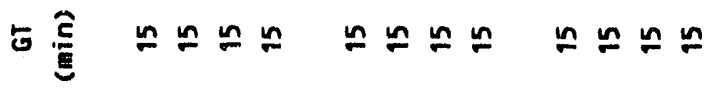

u $\operatorname{sen} n \sin n \sin n$

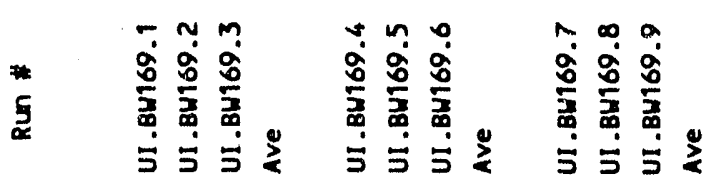




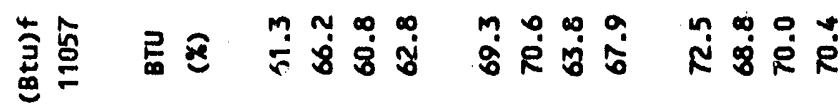

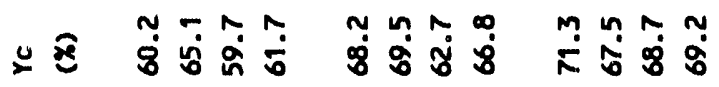

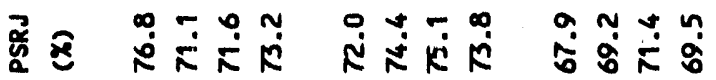

ริำ

จุ 8 ตั

द⿱乛龰己

- ชิ

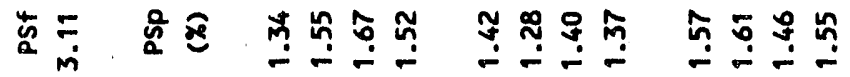

ち马 จ

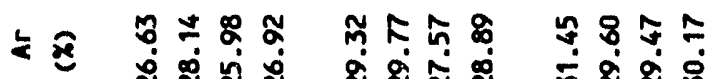

三 ₹

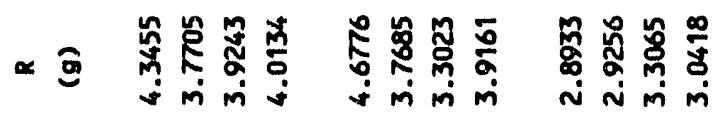

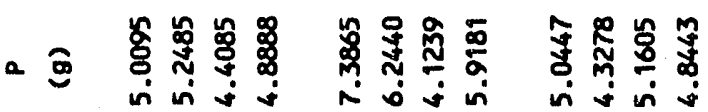

一 重

-

¿

๒

w

: 

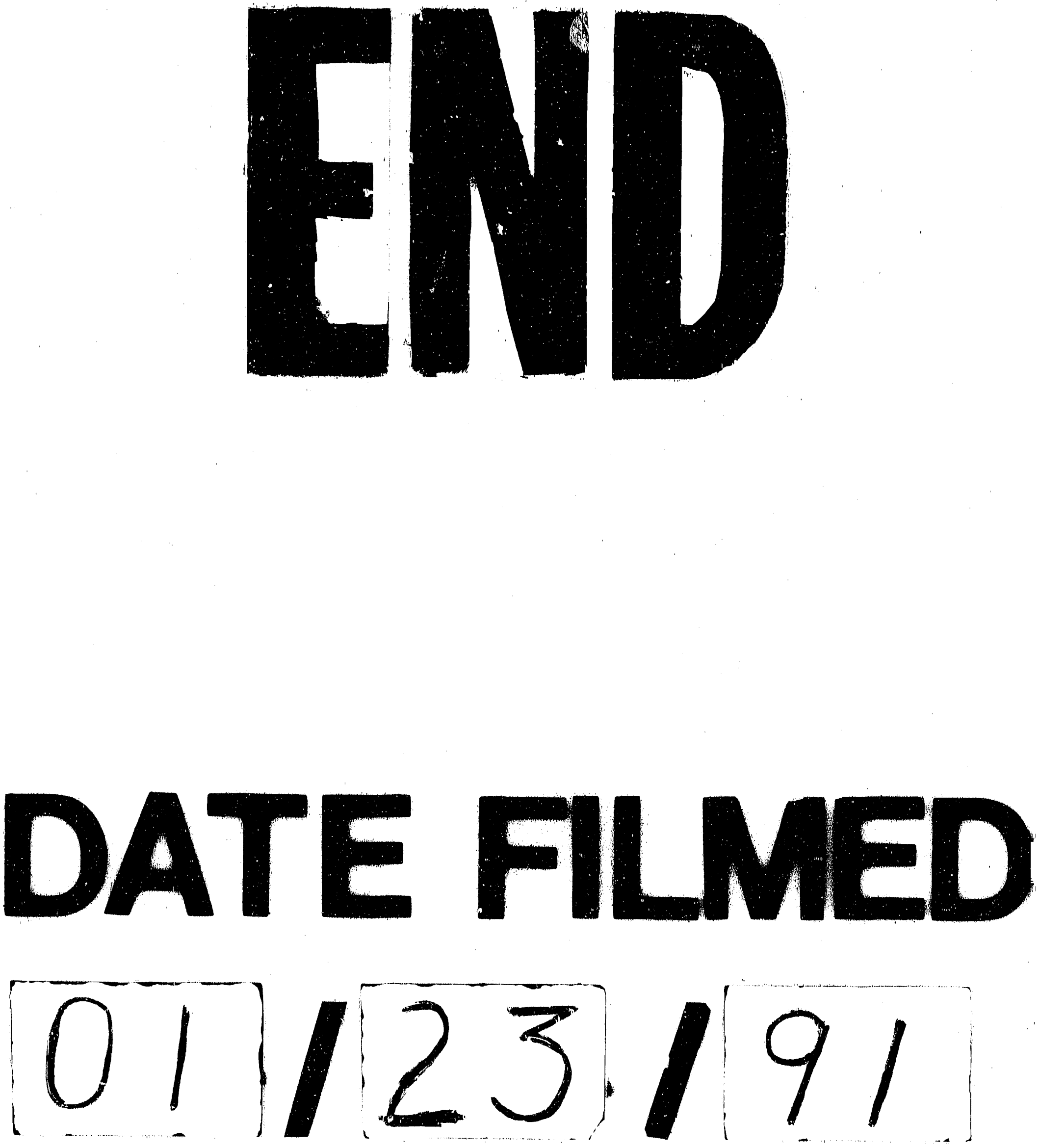
